\title{
Unemployment and the Earnings Structure in Latvia
}

\author{
Mihails Hazans \\ World Bank ECA Region and University of Latvia \\ mihazan@lanet.lv
}

World Bank Policy Research Working Paper 3504, February 2005

The Policy Research Working Paper Series disseminates the findings of work in progress to encourage the exchange of ideas about development issues. An objective of the series is to get the findings out quickly, even if the presentations are less than fully polished. The papers carry the names of the authors and should be cited accordingly. The findings, interpretations, and conclusions expressed in this paper are entirely those of the authors. They do not necessarily represent the view of the World Bank, its Executive Directors, or the countries they represent. Policy Research Working Papers are available online at http://econ.worldbank.org.

This study was initiated in the framework of the research undertaken for the 2003 Latvia Country Economic Memorandum and led by Célestin Monga. The author would like to thank Olivier J. Blanchard, Bernard Funck, and Stefano Scarpetta for comments on a previous draft, and the Latvian Bureau of Statistics for making their data files available. Louise Grogan (University of Guelph) has provided helpful suggestions and editorial assistance. 


\begin{abstract}
Latvia has recorded sustained GDP and productivity growth since 1997. Yet unemployment rates, despite gradual decrease, have remained high. This paper explores the mysteries of unemployment in Latvia. It analyzes labor flows between employment, unemployment, and nonparticipation and finds the following results: First, the type of education and the region of residence appear to be the most important determinants of success in job finding by the unemployed. Second, the unemployed from ethnic minorities have lower chances to find a job within a year, other things equal, while the difference between genders is not significant. However, neither ethnicity nor gender seems to matter as far as the transition from employment to unemployment is concerned. Third, regional disparities in job destruction seem to be less sizable than disparities in job creation. Fourth, the analysis of job search methods by the unemployed indicates that two target groups of state employment policy (young unemployed and longterm unemployed) appear to make relatively little use of the public employment service. The paper also looks at the impact of education, age, gender, ethnicity, and regional factors on individual earnings. The relative position of youths and women in Latvian labor market, compared with prime-age men, is less unfavorable than in many other countries. Yet the gender wage gap has increased recently, and the same is true for regional disparities. Beneficiaries of the so-called "new" education system have a relatively high market value, especially graduates from universities and general secondary schools. Finally, returns to experience seem to be nonexistent for many adult workers without higher education.
\end{abstract}

JEL Classification: J31, J64, J15.

Key words: unemployment; job search; labor market flows; returns to education; age-earnings profiles; wage discrimination; ethnic minorities. 


\section{INTRODUCTION}

Latvia's unemployment rate started at virtually zero at independence in 1991 and reached a peak of 20.7 percent in 1996 (ILO definition). While the unemployment rate has declined to about 12 percent in 2002, only gradually decreasing over recent years, in spite of sustained GDP growth and productivity growth. Explaining this evolution, both over time and across regions, has proven to be a difficult challenge. While several studies carried out by the Latvian authorities have stressed the importance of adverse economic shocks, other analytical studies, mostly from international organizations and academic research centers have emphasized the role of adverse labor market institutions.

Adverse shocks have indeed contributed to the increase in the unemployment rate in Latvia. The country's transformation from a centrally planned to a market economy has been associated with a large reallocation of resources, from public to private as well as from agriculture and industry to services. Explanations of Latvia's high unemployment solely based on adverse shocks do not however tell the whole story. In almost all countries, labor market institutions (or "rigidities") can affect the nature of unemployment and potentially generate a high unemployment rate. In Latvia, it is true that some social programs inherited from the Soviet period became counterproductive with structural and demographic changes that characterized the early years of transition. Latvia has made progress over recent years in designing a flexible labor market: employers gained considerable latitude regarding hiring, firing, and work conditions. Minimum wages are low by international standards, and unemployment insurance is not unsustainably generous. The economy as a whole has also shown some flexibility and change in structure, as evidenced by the decline in public sector employment by over 60 percent between 1992 and 2002, and substantial reallocation of resources from declining to booming sectors.

Thus, the persistence of high unemployment in the dynamic Latvian economy presents a puzzle that this study will try to address. Latvia's transition toward a market economy was obviously much more tham an aggregate demand shock such as that experienced by Western countries several times: it was a systemic shock that implied massive changes in relative prices, huge changes in firms' ownership, large changes in the sectoral composition of the economy, and major shifts in the distribution of income and wages across different strata of the population. All of this took place in a very short period of time.

Following the recommendations of the Lisbon Strategy, ${ }^{1}$ this study will attempt to: (i) establish the impact of the systemic shock implied by transition, the precise nature of the subsequent adverse shocks suffered by the Latvian labor force, the relative importance of shocks and changes in labor market institutions, the specific mechanisms through which institutions and shocks interact; (ii) identify the remaining bottlenecks for a well-functioning labor market; and (iii) draw policy lessons that would foster equity and convergence in Latvia after EU accession. The remainder of the paper is organized as follows: Section 2 analyzes Latvia's labor market (demographics, participation, employment, and unemployment). Section 3 reviews the dynamics of the labor market, focusing on flows, job-finding patterns, determinants of exit from employment, job search methods, and relative wages. Section 4 presents the recent evolution of some key labor market indicators. Section 5 concludes.

\footnotetext{
${ }^{1}$ The European Council of Lisbon set ambitious targets for raising employment rates in the EU by 2010 : to 70 percent for the labor force as a whole and to at least 60 percent for women and to 50 percent for older workers. Latvia currently falls short on all these targets.
} 


\section{ANATOMY OF LATVIA'S LABOR MARKET}

Significant changes to the Latvian labor force have occurred since the transition to a market economy in the early 1990s, and subsequent stabilization. The Latvian population has declined substantially since 1990 and so has the labor force. At the same time, structural changes in the economy have led to labor reallocations between sectors of the economy. As in all transition countries unemployment increased during the first part of the 1990s. However, the economic recovery in the following years has allowed unemployment to stabilize.

This section is devoted to trends and issues in Latvia's labor market, with a specific focus on demographics, employment, and unemployment. Using data from the labor force survey (LFS) we provide an overview of the evolution of labor force participation rates, employment/population ratios, employment composition, and unemployment rates by age and gender for 1997-2002. Latvia's labor market indicators are compared with the ones found in other EU accession countries and selected OECD countries, as well as with the EU-15 average figures.

\section{A. Population Trends}

Effective policy making in Latvia is confounded by demographic trends and uncertainty about the extent of potential labor migration after EU accession which occurred in May 2004. While unemployment will remain a problem in the short to medium term, in the longer term labor shortage is a very likely scenario. The 2003 OECD report warns Baltic countries that "insofar as a possibly emerging scarcity of labor in the future would be unlikely to be offset by a steep rise in immigration or fertility, it will be all the more important to enhance the existing human capital and to ensure that it is productively employed" (OECD, 2003a).

Since the beginning of the transition to a market economy, Latvia has experienced a steep and sustained decline in total population. The population fell from about 2.67 million in 1990 to 2.33 million at the end of 2002 (a drop of about 12 percent or about 1 percent per year). This trend has several explanations, but the key contributing factors have been the negative balance of external migration, low birth rates, and the age structure (see Figures 1 and 2; Box 1). The population decline has not led to a slowdown of economic growth. In fact, recent increases in labor productivity have been so large that Latvia attained an average 5.7 percent real GDP growth during the last 5 years (see Figure 1). This impressive growth was achieved despite the Russian crisis in 1998, which constituted a significant external shock. The growth performance of Latvia appears even more remarkable in per capita terms, at 6.5 percent over the past five years. However, a situation like this will be sustainable only if the labor force is very flexible to the changes in market environment, and has the ability and opportunities to upgrade its capacities.

The decline in the Latvian population is associated both with an increase in the fraction of elderly in the population and with a decrease in fertility. The combination of these factors and a gradual increase in the official retirement age since 1996 has led to a net increase in the proportion of the population of working age (see Figure 3). 
Figure 1. Population and Per Capita Income in Latvia

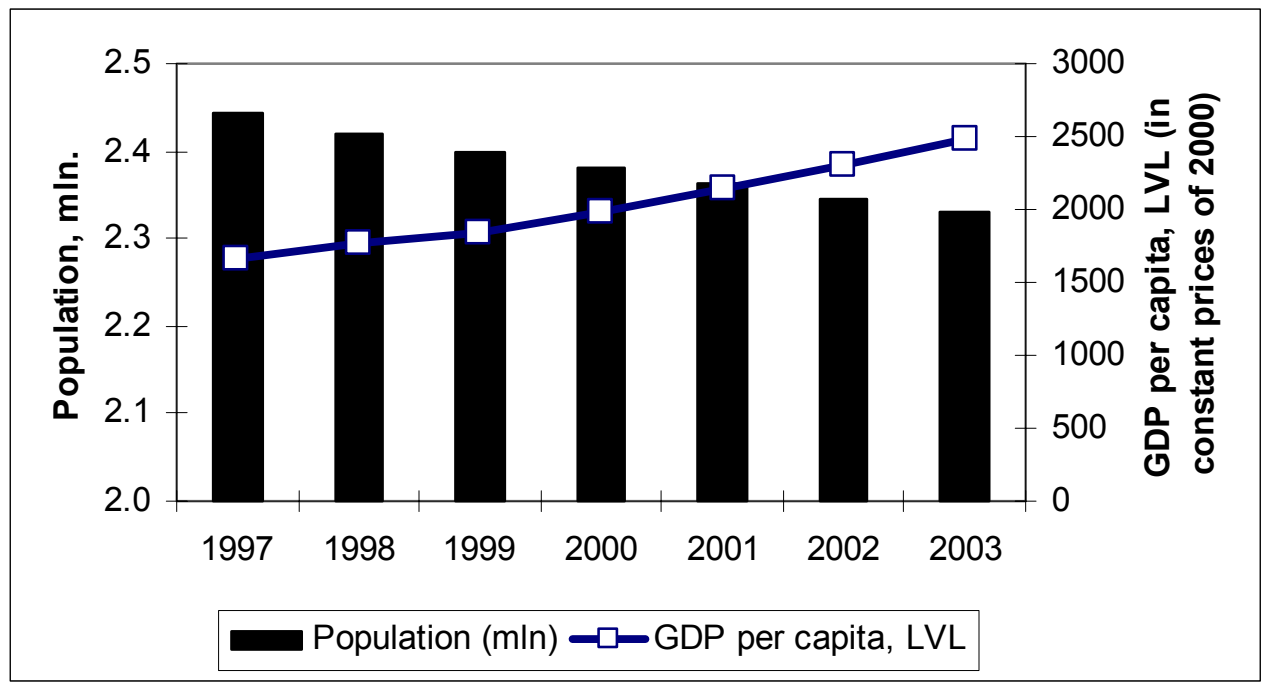

The official old age dependency ratio has been brought down to 346 pensioners per 1000 working age population with the help of pension reforms. This level is below pre-transition value of 368 (see Figure 4). The forecast developed by the Center of Demography of the University of Latvia predicts further falls of this ratio until 2009, followed by an eventual rise to 400 pensioners per 1000 individuals of working age by 2025 (see Appendix Figure 1).

For Latvia, a more useful statistic on old age dependency would be one which takes into account the low labor force participation rates of teenagers, as well as projected rises in both retirement ages and life expectancy. In 2001, life expectancy was 65.2 years for males and 76.6 years for females. A more adequate (and internationally comparable) measure would be the ratio of persons aged 20 to 64 to those aged 65 or more. This ratio has been forecast for Latvia by the ILO and the UN, and is presented in Appendix Figure 2. Note that the projected value for 2002 is 3.95 , very close to the realized 3.87. This statistic suggests an almost unchanged dependency ratio until 2015, but a strong rise in old age dependency thereafter. As shown in Table 1, the cohort currently aged 45 to 64 is smaller than that between 15 and 44 . This is clearly what drives the labor-supply-friendly demographic projection until 2015.

Table 1. Age Distribution of the Latvian Population, January 2003

\begin{tabular}{ccccccccc}
\hline Age & $0-14$ & $15-24$ & $25-34$ & $35-44$ & $45-54$ & $55-64$ & $65+$ & Total \\
\hline \% pop. & 16.3 & 14.9 & 13.8 & 14.6 & 13.2 & 11.6 & 15.7 & 100.0 \\
\hline
\end{tabular}

Source: Demographic yearbook 2003. 


\section{Box 1. Key Causes of Population Decline in Latvia}

Between 1990 and 2002 the population of Latvia declined by about 12 percent. This process of depopulation was caused by several factors. After a gradual opening of the border in the early years of transition, external migration became a major factor in the population decline. Between 1990 and 2002, average net migration from Latvia was 15 thousand persons (or about 0.7 percent of population) per year. However, as shown in Figure 4, net migration rates have leveled off since the mid 1990s.

The rate of natural population increase has also been negative throughout the 1990s. It remains negative today. The rate of natural population decrease (more deaths than births) is estimated at about 12,000 persons or 0.5 percent per annum.

The decline in population may have negative effects on the labor force in Latvia. One of the most important problems in this context is that people deciding to leave the country are most often of working age. Therefore, external migration could put additional pressure on the remaining population to carry social burdens. The natural decrease of the population may be felt most strongly in the long-term. In 10-20 years time the labor force will not receive sufficient numbers of new entrants to maintain itself. In the first three years of this century we have observed a significant decline in the number of primary school students. This trend will continue for at least ten years, because birth rate have not picked up yet. Despite the gradual increase in average income in Latvia, fertility rates have remained low.

Figure 2. Cumulative Natural Increase and Net Migration in Latvia, 1991-2002

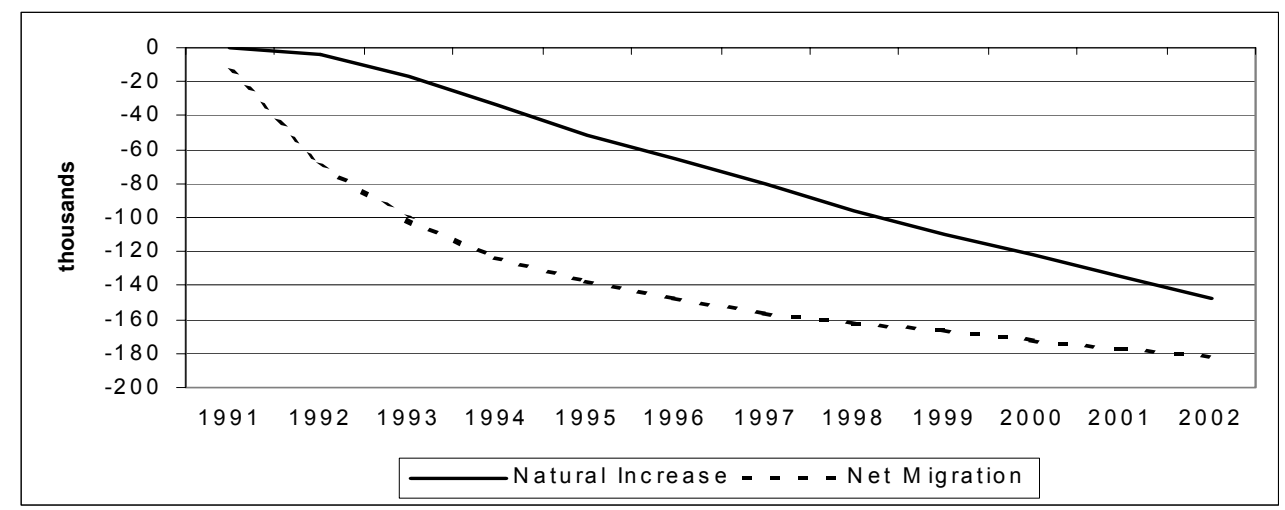

Source: Central Statistical Bureau of Latvia

The possibility of a significant loss of workers due to emigration following EU accession should not be underestimated. Preliminary research (Hazans, 2003b; 2003c) shows that (i) the Latvian population seems to be relatively mobile in comparison with other nations; (ii) significant proportions of skilled nonmanual, clerical and service workers, and students would seriously consider the possibility of moving permanently or temporarily to one of the EU-15 countries if this were possible. The OECD suggests that such potential mobility could have positive effects on the Latvian labor market. According to OECD (2003a), EU accession "should encourage a trend of convergence with [the EU-15] in terms of wages and other labor market conditions". 
Figure 3. Resident Population by Main Age Group at Beginning of Year, 1980-2003

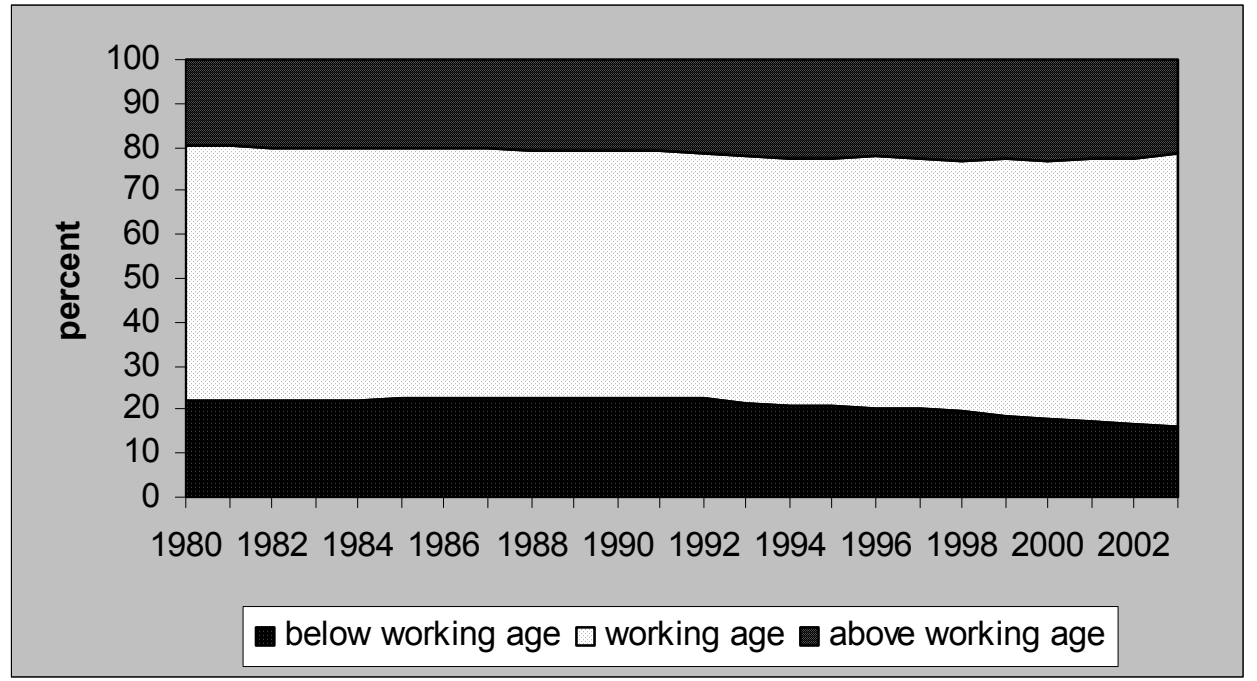

Note: Working age here is defined as 15 to official pension age. The latter was 60 for men and 55 for women until 1996, but has reached 62 and 59 respectively in 2003. Calculations are based on legislation applicable in different years. Source: Central Statistical Bureau of Latvia and Calculations.

Figure 4. Old Age Dependency Ratio, 1980 - 2003

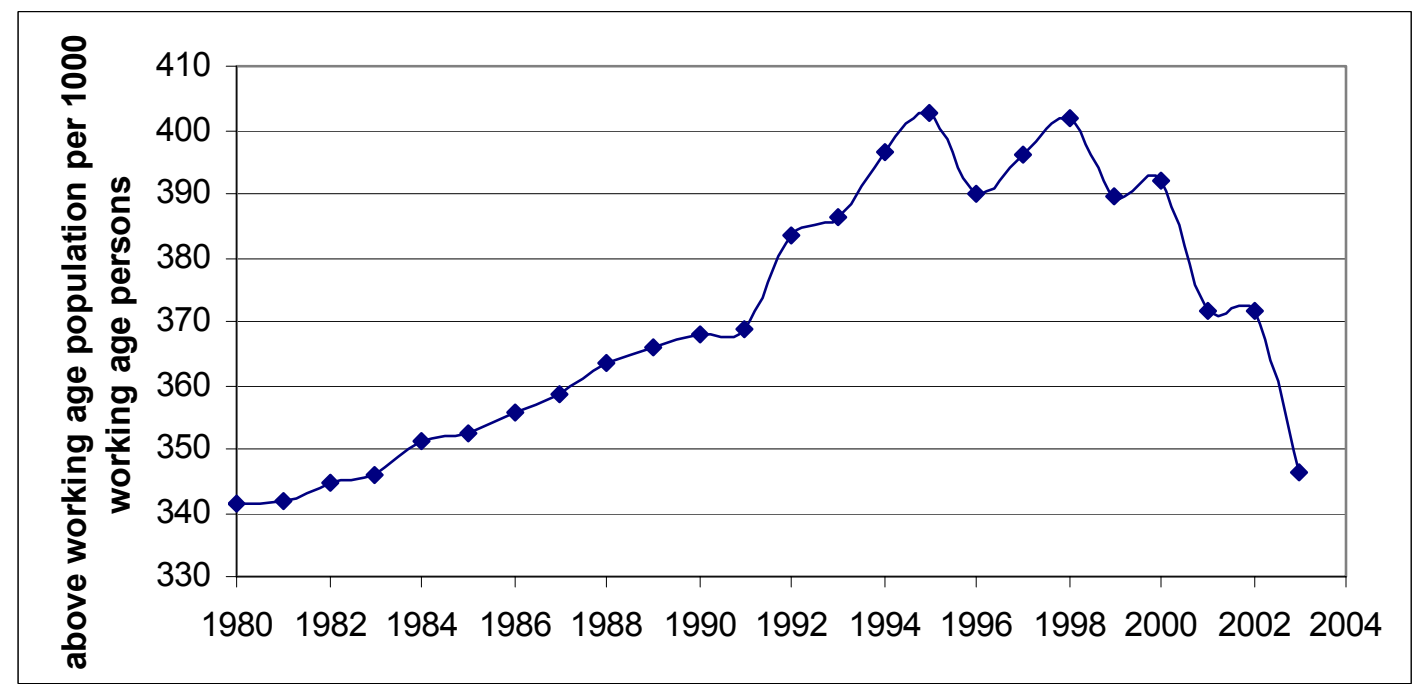

Source: Demographic Yearbook of Latvia, 2003 and own calculations.

\section{B. EMPLOYMENT AND UNEMPLOYMENT: INTERNATIONAL COMPARISONS}

As shown in Figure 5, the contraction of the labor force which accompanied transition ended only ten years later. Employment declined even more sharply than labor force participation during this time, as it did in the other Baltic states. Between 1990 and 2002 employment declined by 30 percent in Latvia. Estonia and Lithuania experienced, respectively, 30 and 25 percent declines in employment in the same period. The Russian financial crisis of August 1998 interrupted post-1996 reductions in ILO-style unemployment and more recent temporary increases in employment. However, since 2000 all three indicators: labor force participation, employment, and unemployment - have featured healthy trends. These recent trends compare favorably to the other Baltic countries. In Lithuania unemployment started to 
decline only in 2002. In Estonia falling unemployment after 2002 led to an increase in employment rates despite slightly declining participation rates.

Figure 5. Evolution of Labor Force, Employment, and Unemployment Rates in Latvia
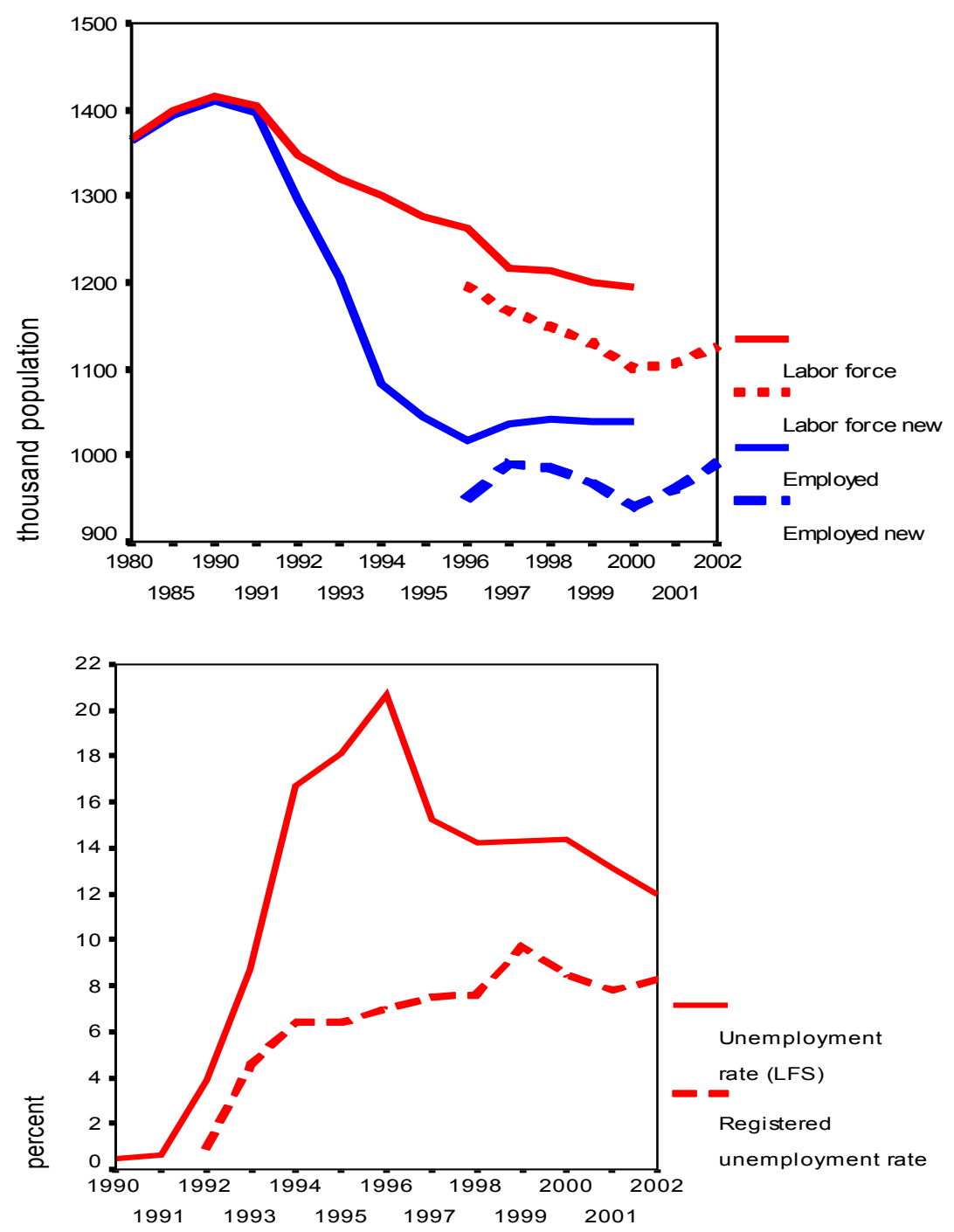

Notes: "Labor force new" and "Employed new" series correspond to recently updated LFS data, while "Labor force" and "Employed" are previously published by Central Statistical Bureau of Latvia data. Harmonized time series are not yet available. LFS unemployment rate is calculated by ILO standards since 1996; for 1990-1995 estimated rate is shown in the Figure.

Source: Central Statistical Bureau of Latvia

How does the Latvian labor market look in a broader international perspective? Figure 6a shows unemployment and labor force participation rates for new EU members. The Latvian labor market compares unfavorably to Estonia, the Czech Republic, Slovenia, and Cyprus on these criteria. Only Bulgaria and Poland have both less favorable activity and unemployment rates. Lithuania and Slovakia have higher unemployment rates than Latvia. Hungary has substantially lower activity and unemployment rates than Latvia. The three Baltic countries and Romania share similar employment - population ratios.

As shown in the Figure 6b, in year 2002 all three Baltic countries had activity rates close to the EU-15 average. Employment/population ratios for the age group 15-64 were, however, lower than the EU-15 
average, while unemployment rates were much higher. Except for Spain and Italy, most countries in Western Europe and North America had higher employment and lower unemployment rates than Latvia.

Figure 6 Activity and Unemployment Rates

a) EU Accession and Candidate Countries (2002), age 15+

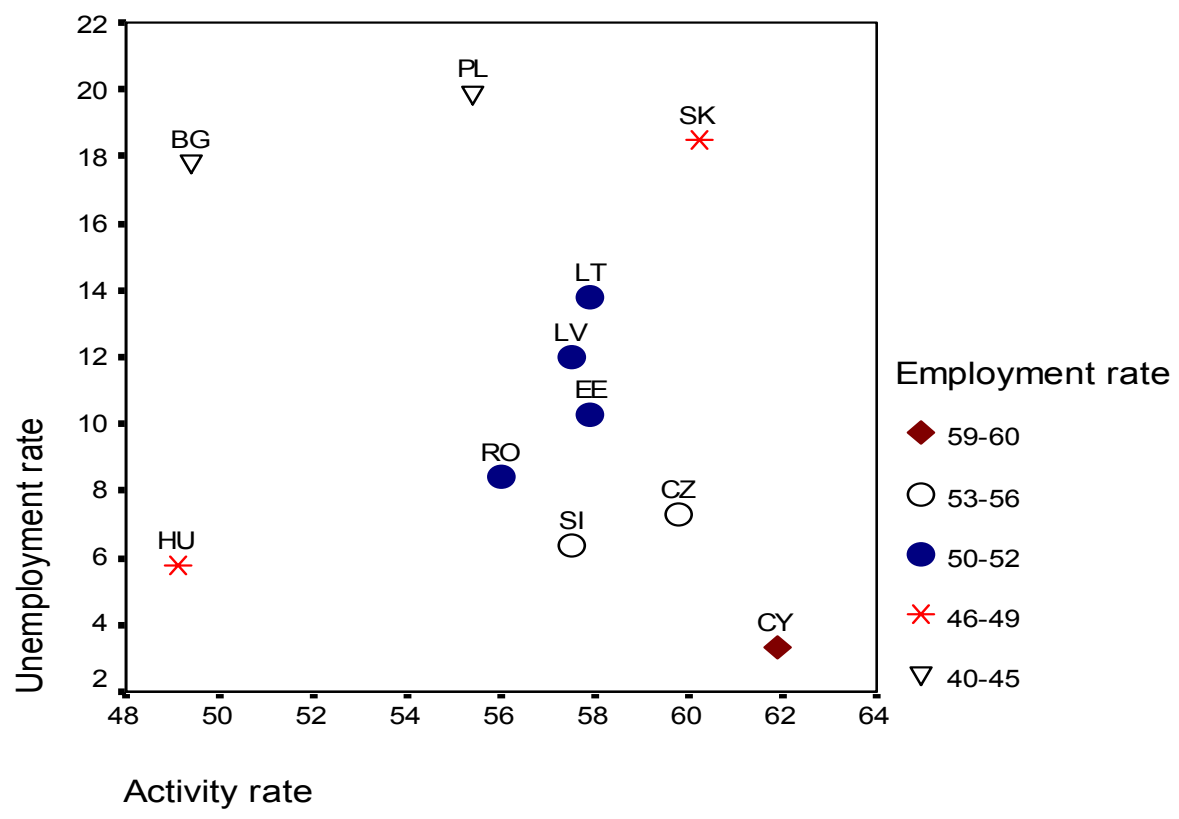

b) Baltic Countries, EU-15 Average, and Selected OECD Countries (2002), age 15-64

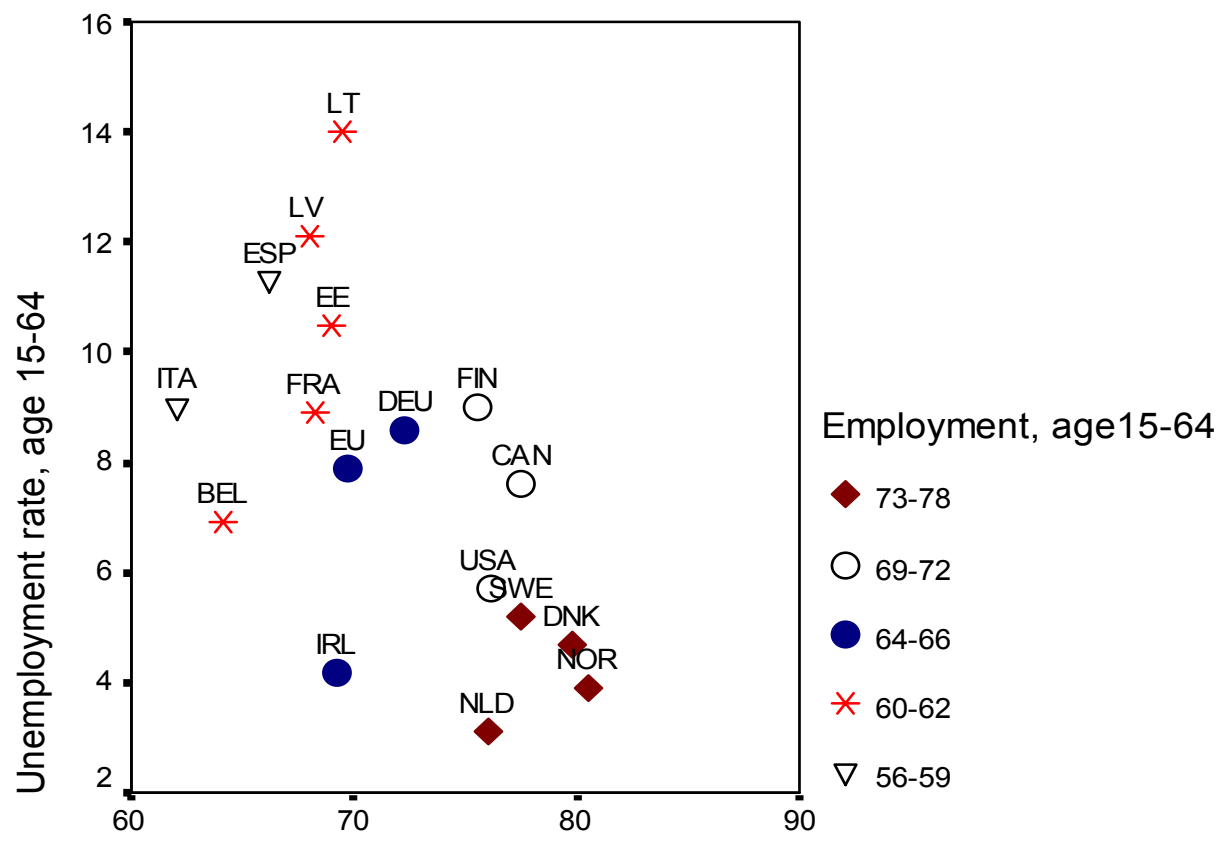

Activity rate, age 15-64

Note: UK and Portugal have virtually identical indicators as Sweden and US respectively.

Source: Canstat 2003/2, national statistical offices of Estonia, Latvia, and Lithuania, OECD, and Calculations. 
Table 2 displays gender-disaggregated labor market indicators for Latvia and the EU-15. Comparison shows that both participation and employment rates in Latvia are higher than the EU-15 average for women but lower for men. Unemployment rates are higher for both genders in Latvia, but especially for men. All indicators of Latvian labor market, which compare unfavorably to the EU-15, became closer to the EU level in 2002, while Latvia's advantage in women's activity and employment has increased. Further progress (especially strong for men) has been made in 2003, when unemployment rates went down, while employment-population ratios increased compared to year ago.

\begin{tabular}{lllllll} 
Table 2. Key Labor Market Indicators: Latvia vs. the EU-15 (age 15-64) \\
\hline & \multicolumn{5}{l}{ Latvia } & \multicolumn{5}{c}{ EU-15 } \\
\hline & $\mathbf{2 0 0 1}$ & $\mathbf{2 0 0 2}$ & $\mathbf{2 0 0 3}$ & $\mathbf{2 0 0 1}$ & $\mathbf{2 0 0 2}$ & $\mathbf{2 0 0 3}$ \\
Activity rate, men & 72.8 & 73.9 & 74.0 & 78.4 & 78.4 & 78.6 \\
Activity rate, women & 62.1 & 64.1 & 64.8 & 60.3 & 61.0 & 61.6 \\
Employment rate, men & 61.8 & 64.3 & 66.1 & 73.3 & 72.9 & 72.7 \\
Employment rate, women & 56.1 & 57.0 & 57.9 & 55.1 & 55.6 & 56.1 \\
Unemployment rate, men & 14.7 & 13.1 & 10.3 & 6.5 & 7.1 & 7.4 \\
\hline Unemployment rate, women & 12.1 & 11.0 & 10.7 & 8.6 & 8.9 & 9.0 \\
\hline
\end{tabular}

Source: Central Statistical Bureau of Latvia and OECD.

\section{LAbor Force Participation ANd EMPloyment}

Activity patterns differ from the EU-15. The "Joint Assessment of Employment Policy Priorities in Latvia" (Stake and Diamantopoulou, 6 February 2003) notes that participation in Latvia is relatively low for young people of both sexes and for prime age males. Participation is high relative to the EU-15 among women aged 25-49. However, it should be noted that youth activity rates can be misleading. In fact, only amongst teenagers is labor force participation low (see Appendix Figure 3). Moreover, in comparison with Central European countries, only the Czech Republic, Romania and Slovakia have higher activity rates in the 15-24 age group.

Youth participation and employment rates have sharply declined in 1998-2001 for men and in 1998-2000 for women; youth unemployment rates have also declined over these periods, although there were temporary increases for men in 1999 and for women in 1998 and 2000. One potential explanation for these developments is an almost 80 percent increase in number of students in higher education institutions per 10,000 population between 1997 and 2001; a 16 percent real wage growth and introduction of students' loans enabled more families to finance their children's education. On the other hand, lack of jobs suitable for students can discourage them from job seeking.

Youth and the elderly are becoming more active. After declining for several years, the overall activity rate for women increased in 2001 by one percentage point due to increased participation in age groups 20-24 and 55-64. This was followed by a one percentage point increase in participation for both sexes in 2002. This increase was primarily due to a decision of the Constitutional Court which reversed previously introduced restrictions on pensions for working pensioners. It may also be related to increased activity amongst male teenagers and young females, potentially stemming from an increase in the minimum wage by 20 percent in July 2001 .

Prime age employment on the rise. In contrast, a general increase in employment and decrease in unemployment in 2001-2002 occurred in the prime age group. Latvian employment rates are above the EU-15 average for women aged 25-64. In 2002 they were below average for young women and for men of all ages, but especially so for teenagers of both sexes ( 9 percent in Latvia compared to the EU-15 
average of 24 percent) and prime age men (Latvia: 78 percent; EU-15 average: 87 percent). Increases in employment rates amongst prime age men are therefore a very desirable development.

\section{COMPOSITION OF EMPLOYMENT}

Service sector growing but still smaller than in the EU-15. As elsewhere, transition resulted in a labor reallocation between the main sectors of the economy. Figure 7 shows that this reallocation was not as rapid in Latvia as in Estonia. Still, reallocation in Latvia was more widespread than in Lithuania. Sectoral change also resulted in more fluctuations than in the other two countries. This comparison with the other Baltic countries suggests that Latvia is not lacking in labor market flexibility.

In recent years the share of employment in industry and construction has remained more or less stable. Compared with the EU-15, the agricultural share of employment (15\%) is still high and the services share $(59 \%)$ relatively low, although it is among the highest among the accession countries. Figure 8 compares these shares across EU accession countries. Labor productivity in agriculture is just 28 percent of that in the other sectors (year 2003 data).

The occupational distribution of employment has stayed almost unchanged since $1996 .{ }^{2}$ Managerial, professional and technical occupations account for 34 percent, skilled and unskilled manual occupations for 48 percent, and clerical, sales and service occupations for about 18 percent of employment in Latvia. Clerical and service jobs still account for a much lower proportion of overall employment than in the EU15 countries, where 27 percent of all jobs belonged to this category in 2000. Clerical and service jobs also make up a lower fraction of employment in Latvia than in Hungary, the Czech Republic, Bulgaria or Poland.

Self-employment is underdeveloped. Self-employment in Latvia is concentrated primarily in agriculture (see Box 2 and Appendix Table 2). It is less common than in the EU-15 in all sectors $(35.8 \% \mathrm{vs} 52 \%$ in agriculture, $4.7 \%$ vs $11 \%$ in industry, and $6.5 \%$ vs $13 \%$ in services). As shown in Figure 9, selfemployment is also is less common than in most Central and Eastern European countries.

Too few part-time jobs or too few full-time ones? The proportion of part-time workers has declined from 13 percent in 1997 to less than 10 percent of all workers employed in 2002. In the EU-15 this fraction is 18 percent. While the decline of part-time employment was particularly strong for men (see Appendix Figure 4 and Appendix Table 3 for more details), the contrast between Latvia and the EU-15 is especially sharp for women. Only 12 percent of women workers are part-time in Latvia, while 33.5 percent are in the EU-15. In other Central European countries, except Romania and Poland, the proportion of part-time workers is even lower than in Latvia, in some cases substantially. Latvia also has one of the highest shares of temporary and seasonal employees among the accession countries; in 2002 this share has reached 14 percent (Figure 10 displays a lower proportion, 12 percent, for the second quarter).

While the proportion of part-time workers among employed females has been stable during the last 5 years, for males this fraction has dropped from 12.5 percent to 7.7 percent. Part-time employment is an important way of enhancing labor market flexibility, so the relatively low percentage of part-time workers, together with low youth activity rates might suggest that there are too few part-time jobs on offer for young people. Part-time work, however, does not only indicate labor market flexibility. According to LFS 2002 data, 45 percent of part-time workers in Latvia would have preferred to work full time in their main job. Such acceptance of less-than-desired hours of work is one of the most common definitions of

\footnotetext{
${ }^{2}$ According to enterprise survey on occupations, however, share of manual workers among employees declines slowly but steadily at the expense of the two other groups.
} 
underemployment ${ }^{3}$. In all age groups, only a minority of jobseekers report preferences for part-time jobs (Appendix Table 7). The probability of having a part-time job as the primary job is decreasing in education. Thus it appears that part-time employment in Latvia is largely a result of a shortage of fulltime jobs.

Figure 7. Labor Reallocation Between Main Sectors, 1990-2002

(Estonia, upper panel; Latvia, middle; Lithuania, bottom)
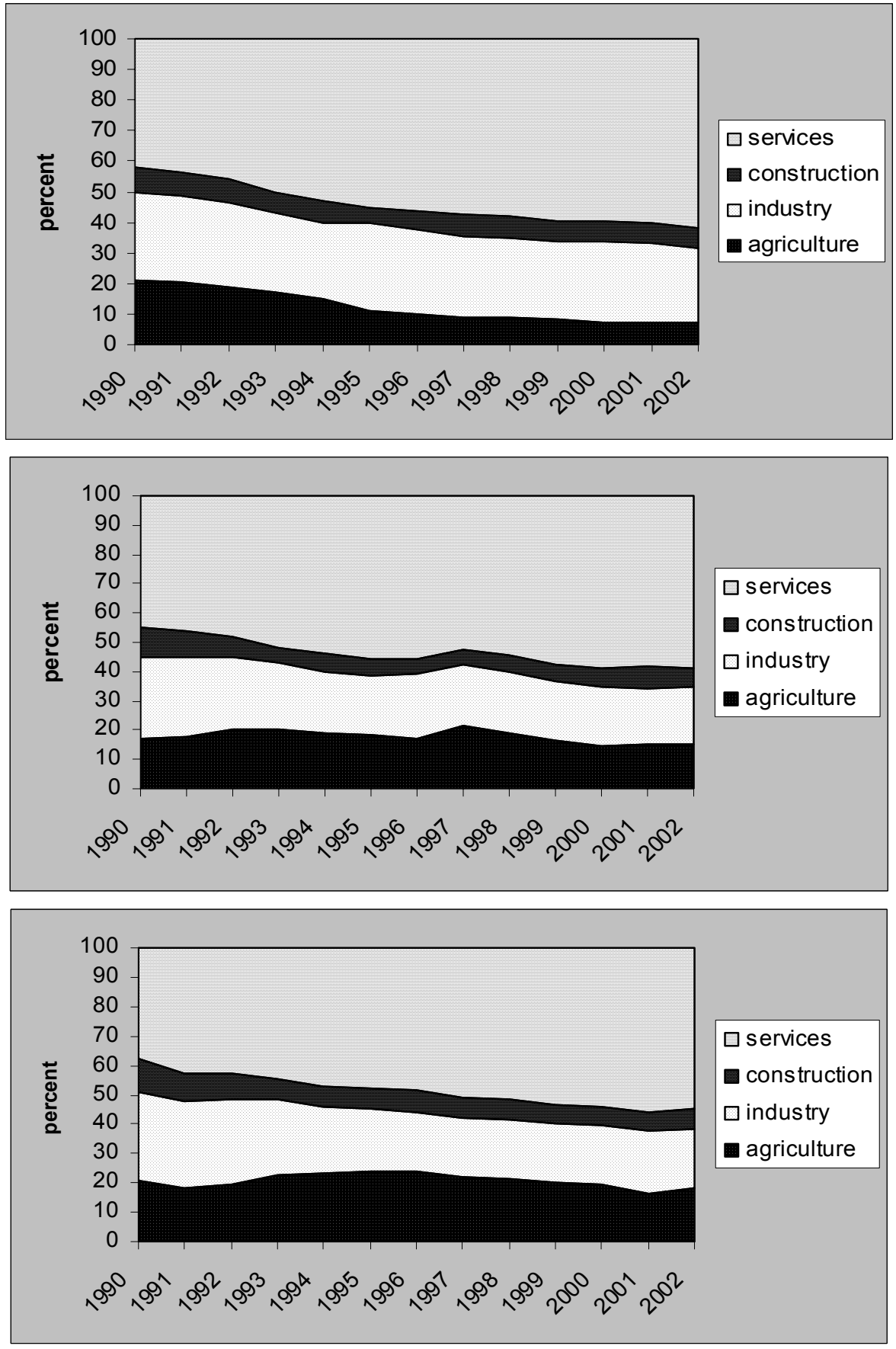

Source: National statist ical offices of Estonia, Latvia, and Lithuania

\footnotetext{
${ }^{3}$ See Trapeznikova et al. (2003) for in-depth study of part-time employment and underemployment in Latvia.
} 
Another form of latent unemployment is involuntary temporary work: in 2002 about 5 percent of all employees (full-time and part-time) accepted fixed-term contracts because they were unable to find permanent jobs. While temporary employment gives employers more flexibility in their personnel practices, it has obvious negative consequences for the economic security of labor market participants.

Figure 8. Employment by Main Sectors in the EU Accession and Candidate Countries, 2002

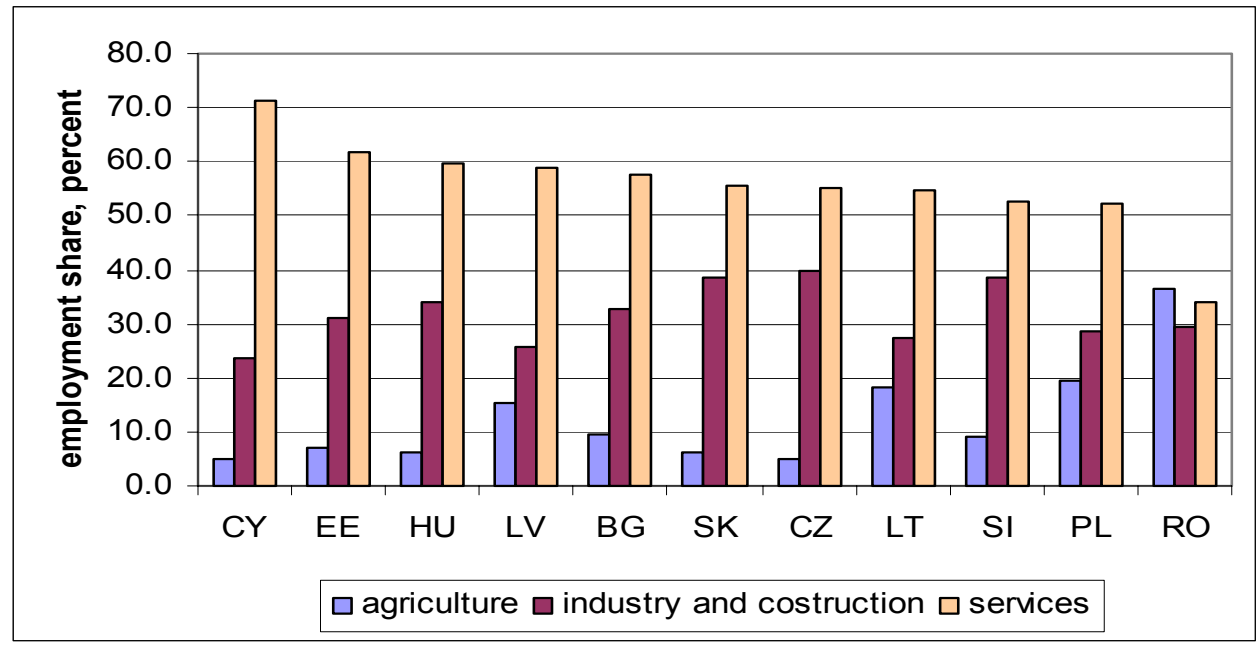

Source: Canstat 2003/2

Figure 9. Self-Employment Share in Total Employment in Central European Countries

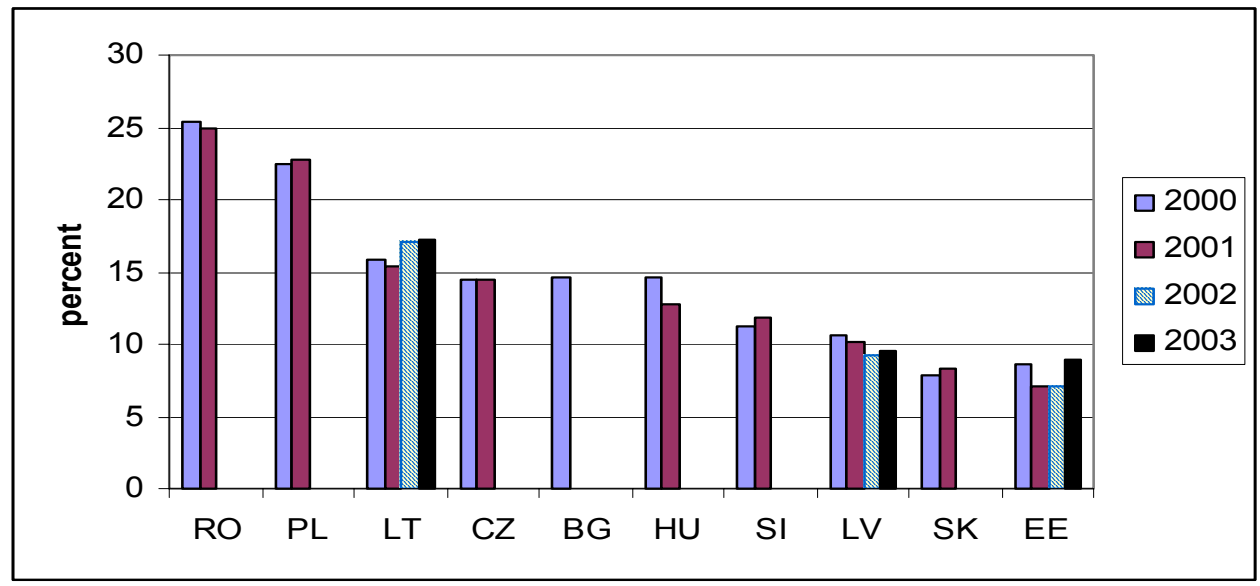

Source: ILO (Laborsta database) and national statistical offices; $2^{\text {nd }}$ quarter. 
Figure 10. Part-Time and Temporary Employment in the EU Accession and Candidate Countries, 2002

(as percent of total employment and of all employees respectively)

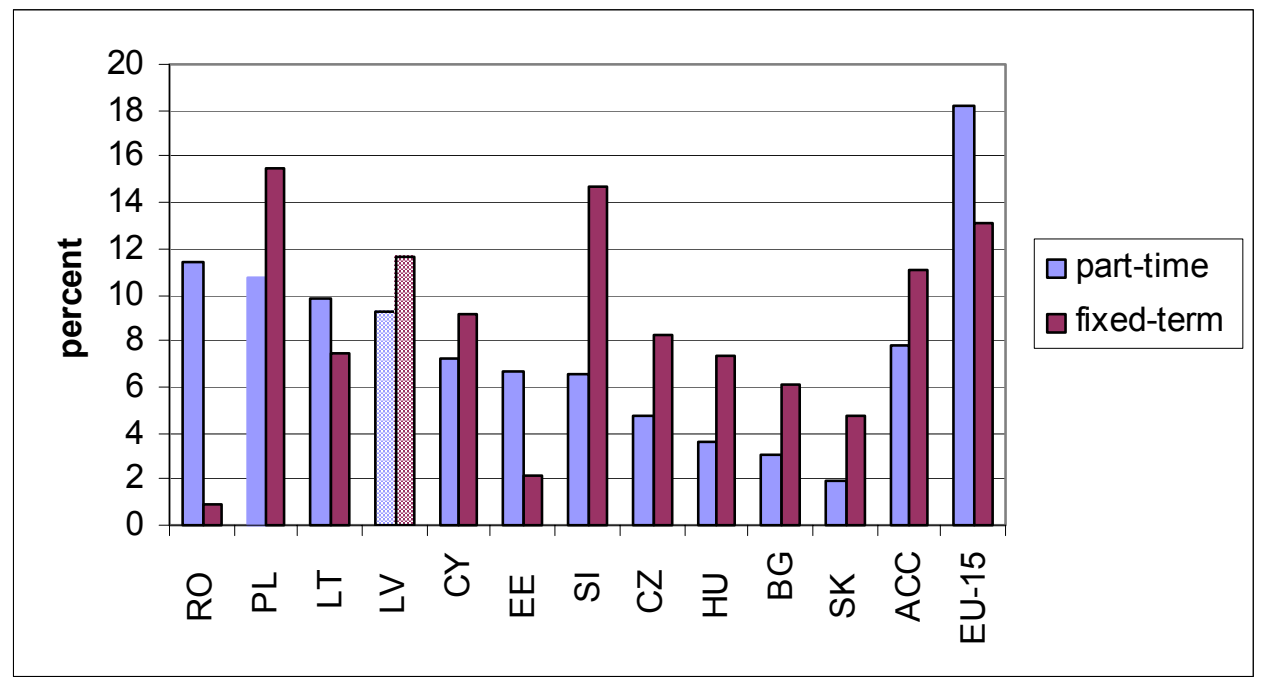

Notes: ACC - EU accession and candidate countries. Source: Eurostat (based on $2^{\text {nd }}$ quarter LFS data).

\section{Box 2. Self Employment in the Latvian Economy}

The share of self-employed among the employed the extent to which employment is based on one's own capital resources and carried at one's own risk. As self-employment was often restricted in socialist countries, the share of self-employment can be seen as a gauge of progress towards a market-oriented economy. Furthermore, the establishment of additional enterprises in expanding sectors of the economy is very important for job creation. Still, it is apparent that some of the self-employment in transition economies is a low productivity, semi-legal alternative to joining the ranks of the unemployed. This may be a rational response on the part of those who lose, or are in danger of losing, their attachment to the formal labor market.

The data in the table below confirm the relation between self-employment and the agricultural character of the regions. In Romania, more than $20 \%$ of employed workers are self-employed in agriculture. In Poland this fraction is $12.7 \%$, but in three regions of the country the share also lies at around 25 percent. In contrast, in Latvia the share of self-employment is only 5.5 percent.

The industrial sectors of all countries generally have few self-employed individuals. In the Czech Republic, selfemployment activities are most widespread in the industrial sector of regions with an unemployment rate between 4 and 6 percent. In Hungary, this group accounts for 3.7 percent of the total employment in industry. In Bulgaria, the Baltic States and Romania however, hardly any self-employed are found in the industrial sector. These selfemployed account for less than 2 percent of the employed in these countries.

In all countries, most of the self-employed work in the service sector rather than in the industrial sector. The employment share in services is particularly high in the Czech Republic with 8.9 percent, and Hungary with 8.4 percent. In Latvia, as in Lithuania, Romania and Bulgaria, the self-employment rate in the service sector is lower than in the agricultural sector.

\begin{tabular}{|c|c|c|c|c|}
\hline & \multirow{2}{*}{$\begin{array}{l}\text { Self-employment } \\
\text { rate }\end{array}$} & \multicolumn{3}{|c|}{ Contribution of sectors } \\
\hline & & Agriculture & Industry & Services \\
\hline Bulgaria & 14.6 & 7.2 & 1.5 & 5.8 \\
\hline Czech Republic & 14.5 & 0.9 & 4.6 & 8.9 \\
\hline Estonia & 8.1 & 2.1 & 1.3 & 4.7 \\
\hline
\end{tabular}




\begin{tabular}{lrrrr} 
Hungary & 14.6 & 2.6 & 3.7 & 4.7 \\
Lithuania & 15.9 & 11.1 & 0.9 & 4 \\
Latvia & $\mathbf{1 0 . 5}$ & $\mathbf{5 . 5}$ & $\mathbf{1 . 3}$ & 7.1 \\
Poland & 22.5 & 12.7 & 2.7 & 2.6 \\
Romania & 25.4 & 21.9 & 0.9 & 4.7 \\
Slovenia & 11.2 & 3.8 & 2.6 & 4.7 \\
Slovakia & 7.8 & 0.4 & 2.7 & 5.8 \\
CEC-10 & 19.5 & 11.3 & 2.4 & \\
\hline
\end{tabular}

Source: Eurostat, Employment and labor market in Central Europe 2001/2

Second jobs play an important role. The number of part-time jobs in the economy greatly exceeds that of part-time workers. Apart from those whose main job is a part-time one, 7 percent of those employed in 2002 have at least one second job. Second jobs are typically part-time. The prevalence of second jobs is most likely underestimated in the 2002 LFS, because respondents whose information was given by another household member report a second job 1.5 times less frequently than those interviewed directly.

According to an enterprise survey on wages and hours worked, 13 percent of public sector employees had second jobs in 2002. In such sectors as financial intermediation, business, education and other community and personal services, the proportion was much higher. Two thirds of second jobs are in the service sector. The shares of individuals engaged in managerial, professional and technical occupations in secondary jobs are higher that those in primary jobs. Appendix Figure 4 sums up some recent trends in employment patterns in Latvia.

\section{E. UNEMPLOYMENT RATES}

This section will look at the structure of unemployment in Latvia. In Figure 6, it was shown that the level of unemployment in Latvia is still high by international standards. As elsewhere, youth unemployment is higher than unemployment among older workers (see Appendix Figure 3). However, as shown in Figure 11 , the ratio of youth to adult unemployment rates, as well as the female - male unemployment ratio is among the lowest in Europe. This suggests that, relative to other European countries, youth and women in Latvia have relatively advantageous employment prospects.

Figure 11. Ratio of Unemployment Rates by Age and Gender. CEC-10 and EU-15, 2002

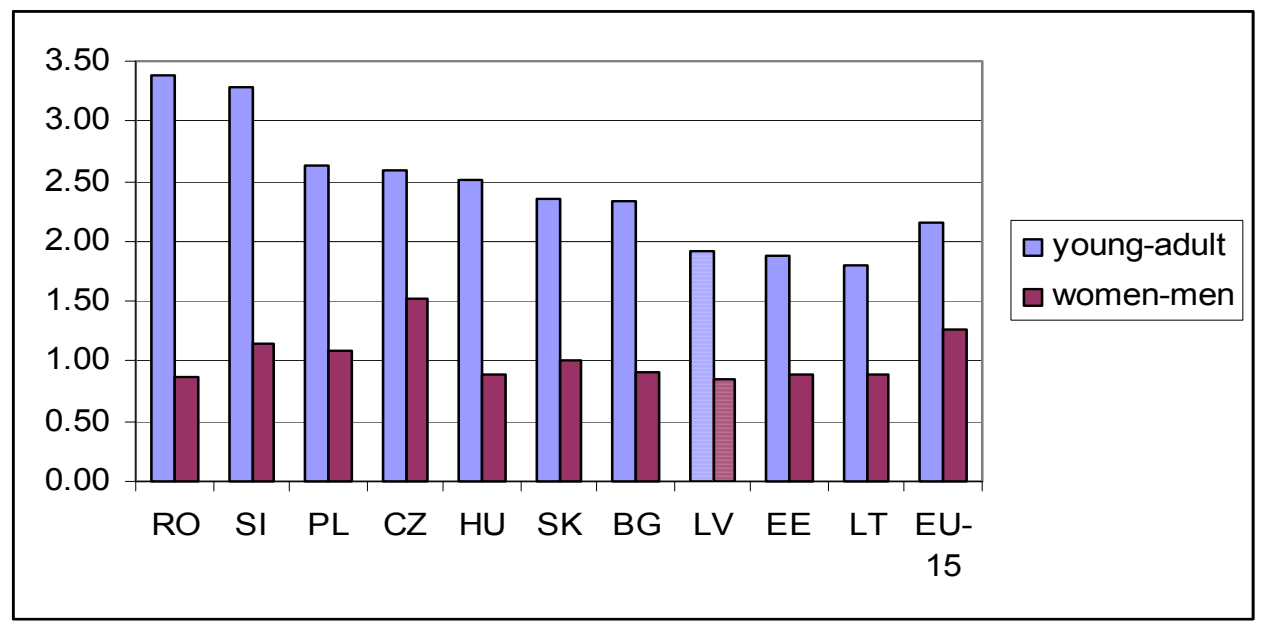

Source: Canstat 2003/3, OECD, and author's calculation. 
As in a majority of countries, the unemployment rate is negatively related to the level of education of individuals (see Appendix Table 4). On average, members of the labor force with higher education face an approximately 2 times lower unemployment risk than their counterparts with upper secondary education. This degree of difference in unemployment rates amongst education groups is similar to that found in Lithuania, but somewhat lower than those measured for other Central European countries (see Appendix Figure 5).

Ethnic considerations. Unemployment is higher amongst non-Latvians than among ethnic Latvians. Until 2001, the unemployment rates were about 1.8 times larger for ethnic minorities in comparison with Latvians. In 2002, however, this ratio fell to 1.5 as a result of a decline in unemployment among nonLatvians. Evidence from the 2000 Population Census (see Appendix Table 4) suggests that the ethnic gap in unemployment rates is caused mainly, but not entirely, by a lack of Latvian language skills. Another factor which contributes to the difference in unemployment rates between Latvians and ethnic minorities is that the Latgale region, with the highest unemployment rates in the country, is predominantly populated by non-Latvians.

Figure 12. Unemployment Rates by Ethnicity: Ethnic Minorities vs. Majority Population. Estonia and Latvia, 1997-2002

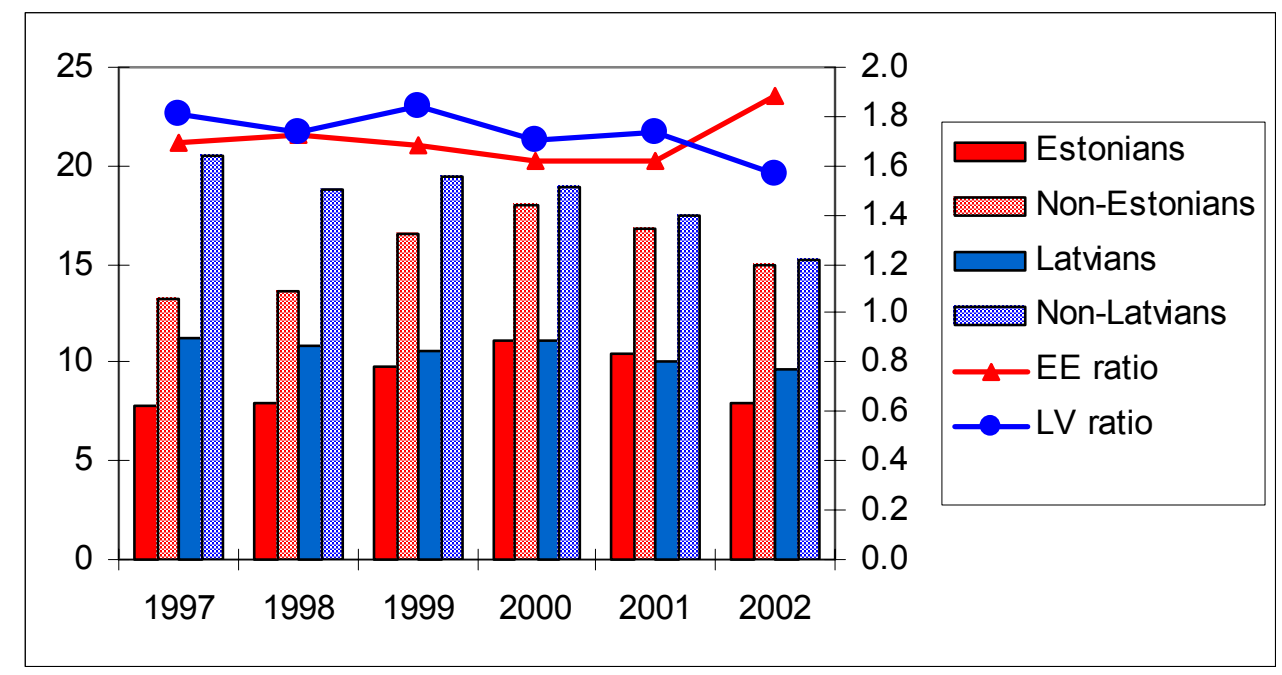

Source: Calculation based on LFS data.

Unemployment duration. As in other transition countries, long-term unemployment is one of the most acute problems facing the Latvian labor market. Long-term unemployment generally refers to the unemployment spells which exceed one year. Appendix Table 5 shows the distribution of unemployed persons by education and duration of unemployment. Appendix Figure 6 shows that between 2000 and 2002 Latvia performed much better than other countries of Central and Eastern Europe in reducing longterm unemployment. In the second quarter of 2002 incidence of long-term unemployment in Latvia, 42 percent, was at the same level as in the EU-15. This was the first year since 1996 in which less than half of the unemployed (annual average 46.4\%) were unable to find a job within the year. In 2003 incidence of long-term unemployment decreased to $43.8 \%$.

Appendix Table 6 describes how long-term unemployment has evolved in the Baltic countries since 1997. A decrease of this indicator by 12 percentage points between 2001 and 2002 is cause for optimism in Latvia. Still, the design of policies for fighting long-term unemployment requires a deeper insight into the following issues: (i.) Identifying individuals who are most likely to experience unemployment, and those who are most likely to experience long-term unemployment conditional on job loss; (ii.) Determining 
whether or not long-term unemployment is primarily a result of ineffective job search. These two questions will be dealt with in subsequent sections.

As far as the composition of long-term unemployment is concerned, 72 percent of long-term unemployed belong to the prime-age group (25-54). Non-Latvians constitute 58 percent of the long-term unemployed. 28 percent of the long-term unemployed have basic education or less, and another 21 percent have professional basic education (ISCED 2C) or vocational (professional after basic, possibly followed by a fast-track general secondary) education (ISCED 3C, ISCED4A).

\section{F. REGIONAL DISPARITIES AND COMMUTING}

There are four major dimensions of geographical disparities in Latvia: (i.) urban - rural; (ii.) Riga region - other territory; (iii.) inter-regional disparities between the five NUTS 3 regions (Riga region, Vidzeme, Zemgale, Kurzeme, Latgale), and (iv.) between 33 NUTS 4 regions (7 main cities and 26 districts).

Income and employment prospects are better in cities than in the countryside and in Riga compared to other cities. The division between urban and rural residents (and also between metropolitan and other areas) reveals itself most clearly as income inequality. According to Household Budget Survey results, per capita income in rural areas in 2000 (as well as per capita consumption expenditure in 2002) was on average just 69 percent of that in cities. This is a very significant fall since 1996, when the rural-urban income ratio was 90 percent.

Although unemployment is higher in Latvia's urban areas compared to the countryside (13.2 versus 9.0 percent in 2002), intuition that higher wages in cities are being balanced out by lower employment possibilities (as in the classic Harris-Todaro model) is misleading. In fact, according to LFS 2002, the number of paid jobs located in the rural areas is just 50 percent of number of economically active residents, while this ratio is 95 percent in Riga and 79 percent in other cities (see also Appendix Table 8). In other words, employment possibilities are positively rather than negatively correlated with wages. ${ }^{4}$ In Riga, where employment prospects are the best, the LFS-based unemployment rate is below average, and the registered unemployment rate is lower than elsewhere (see Figure 13 and Appendix Table 9).

Commuting helps to reduce disparities (Hazans 2004a). Commuting is the way in which the population of rural areas and small cities deals with geographical disparities in wages and unemployment. Appendix Table 10 describes commuting flows between rural and urban areas in Latvia and Lithuania in year 2000. One-third of full-time employees living in Latvian countryside had their jobs in cities (this proportion increased to 40 percent in 2002). More than 40 percent of employees living in small cities near Riga, and about 10 percent of those living in other cities, worked in Riga. Commuters enjoy significant earnings gains. According to calculations using the 2000 LFS, a rural resident commuting a distance of 50 $\mathrm{km}$ obtains a 53 percent ceteris paribus gain compared to non-commuters. A resident of a city outside Riga obtains a 35 percent gain (see Hazans 2003a, 2004a).

By integrating local labor markets, commuting works to reduce the overall wage gap and disparities in employment prospects between Riga and rural areas, as well as between Riga and other cities. By shifting labor from the countryside to cities, commuting, at least in the short run, increases national output (see Hazans 2004a).

\footnotetext{
${ }^{4}$ Consistent with the wage curve model (Blanchflower and Oswald (1994)), especially relevant in the context of inter-regional (rather than urban-rural) disparities; see section 4 for estimates of Latvian wage curve.
} 
NUTS 3 regions: uneven development. Figure 13 gives a simple description of labor market conditions in Latvia's regions in 2002. The Riga region is well ahead, while Latgale seems to be depressed, and differences between the other three regions are relatively small; somewhat higher wages in Kurzeme have to be seen against lower unemployment rates in Vidzeme and Zemgale. Some recent, unfavorable, developments in Vidzeme are, however, documented in Section 3, below. On the other hand, unemployment rate in Latgale dropped from 21 percent in 2000 to 17 percent in 2002 (Appendix Table 9). Nevertheless, the difference in unemployment rates (both LFS-based and registered) between the Riga region and Latgale is striking given the small size of the country. This is especially true when combined with the $60 \%$ wage advantage in Riga (Figure 13) and a much higher share of discouraged workers in Latgale (Appendix Table 11). The fact that State Employment Service was until recently only available to jobseekers at their official place of residence clearly added to labor market rigidities. Still, the problems of Latgale, a relatively remote region, would not be solved by commuting or (at least in the medium term) by migration. Thus, job creation in this region is essential.

Figure 13. Unemployment Rates (left scale, percent) and Relative Average Wages (right scale) in Latvia's Regions, 2002

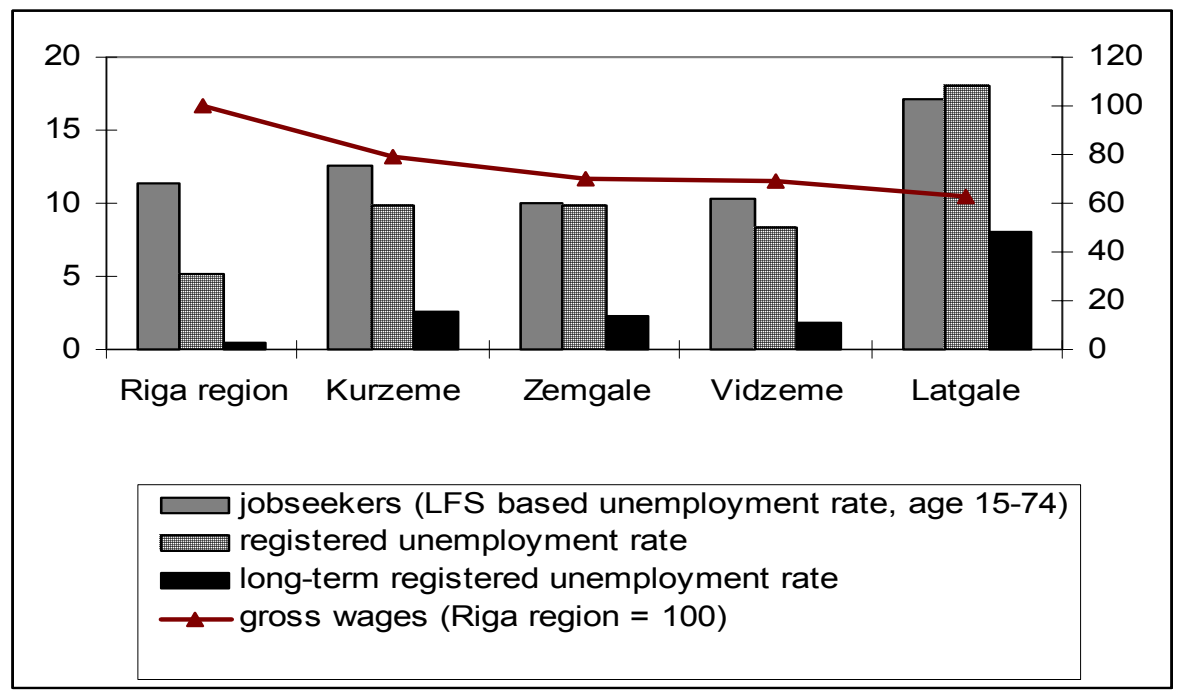

Source: Central Statistical Bureau of Latvia and Calculations. Registered unemployment rates are based on number of economically active population in the age brackets from 15 years to the retirement age.

Evolution of regional labor markets. A large increase in the unemployment gap between Latgale and the rest of the country emerged in 1993-1995 (see Appendix Figure 8). Since this time, the general trend was of an improving the relative standing of this region in terms of unemployment. However, a further worsening in wages disparities between Latgale and other regions was experienced. The relative wage advantage of Kurzeme declined between 1993 and 2000. Recently, unemployment rates have become more similar to those in other regions. The position of the Zemgale labor market (as seen from the perspective of administrative data) was more or less stable throughout the whole period. During the last three years wage growth was very similar across all regions except Kurzeme, where it was slower. Vidzeme was the only region in which registered unemployment increased. A deeper analysis in the next chapter shows, however, that the gap between Riga and other regions both in terms of relative wages and unemployment risk in 2002 was wider than five years ago.

NUTS 4 regions: persistent disparities. Labor market conditions also differ within the five NUTS 3 regions. Appendix Figure 7 suggests a negative relationship between unemployment rates and wage levels across districts. The 33 NUTS 4 level regions include Riga, with three-quarters of a million residents, 6 
other major cities of 38 to 115,000 residents, and 26 districts (most of which have between 25,000 and 65,000 residents). The persistence of unemployment is suggested by the fact that the correlation between end-of-year unemployment rates in 1993 and 2002 across 33 NUTS 3 regions is 0.77 . The correlation in year-on-year unemployment rates varies from 0.925 to 0.991 in the 1995-2002 period.

Appendix Figure 9 and Appendix Tables 12 and 13 show that overall disparities in local unemployment increased sharply until 1994, fell between 1994 and 1998, and rose again in 1999-2001. These trends were driven by trends in districts with above-average unemployment. This pattern holds true whether or not weights for the size of the local labor force are taken into account. The picture does not change either when the 7 major cities of Latvia are included in the adjacent districts. Appendix Figure 9 also charts the evolution of the "unemployment Gini index", which is calculated in the same way as the usual "income Gini" and measures inter-regional inequity of distribution of unemployed persons in country's labor force (ignoring inequity within districts in question). Recent values of Gini (0.31) are quite close to Latvia's income Gini (0.34 in 2001). This Gini value suggests a much more uneven distribution of unemployment than, say, in Lithuania. According to this measure, the Lithuanian unemployment Gini is about 0.20.

Persistence in wages has been even stronger than that of unemployment. Year-on-year wage correlations across districts vary between 0.954 and 0.992 . The correlation for 1992-2002 is 0.92 . The overall level of disparities, as measured by Gini or weighted coefficients of variation, fell in 1993-1995. Since then, inter-district wage disparities appear to have remained stable. This trend is shown in the left bottom panel of Appendix Figure 9.

Still, non-weighted measures of inter-regional wage disparities, which do not account for variation in the number of workers in regions, show that such differences have been declining since 1996. In other words, the position of small low-income districts is gradually improving. This is shown in the right bottom panel of Appendix Figure 9. The wage advantage of Riga and some other major cities has been shaping the trend. Disparities between average wages of NUTS4 regions account for approximately $25 \%$ of overall inequality of in the wage distribution of Latvia.

The next section analyzes labor market dynamics in Latvia over recent years, focusing on flows between employment, unemployment, and inactivity; determinants of exit from unemployment; job search methods of unemployed; and the evolution of relative wages. 


\section{RECENT LABOR MARKET DYNAMICS}

We start with an analysis of labor flows between the three possible labor states, employment, unemployment, and nonparticipation (sub-sections A, B, and C). For those employed, we study mobility between different sectors. Light is shed on the process of economic restructuring by relating the processes of job reallocation, job creation, and job destruction. The groups who experience difficulty in the labor market are identified via analysis of factors influencing the probability of losing and finding jobs, and exiting to nonparticipation. Subsections D and E examine the determinants of job search methods by the unemployed, as well as the determinants of individual earnings, focusing on the impact of education, age, gender, and regional factors.

\section{A. FLOWS BETWEEN EMPLOYMENT, UNEMPLOYMENT, AND INACTIVITY}

The high level of outflows from jobs in Latvia is suggested by the fact that a substantial proportion of those employed in any year are not employed one year later. However, this fraction has declined from 10 to 8 percent over the last 5 years. The net inflow into employment is now positive in Latvia. Inflows to employment were smaller in 1997-1999 but larger starting from 2001, so that an initial trend towards declining employment rates has been reversed. This is shown in Figure 14 (see Appendix Table 14 for details). The Russian financial crisis of 1998 resulted in big net outflow between 1998 and 1999.

Figure 14. Flows from and to Employment, 1997-2002

(as proportion of employment in the first of the two periods)

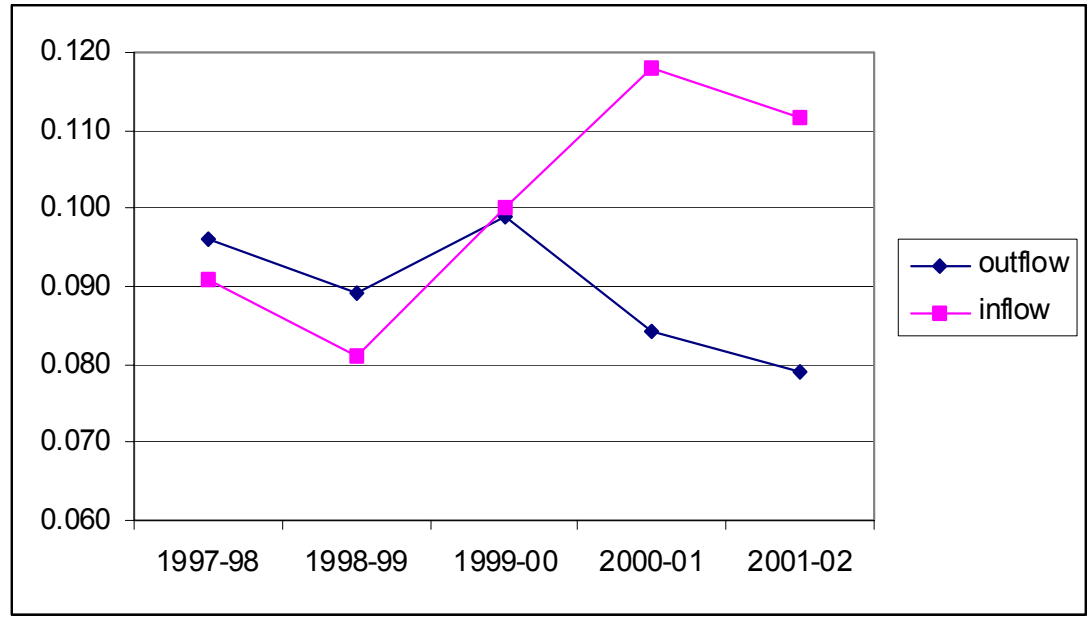

Notes: 1997-2001: flows between Mays of corresponding years; 2001-2002 - annual average. Flows exclude the impact of migration, mortality, and new entrants who were younger than 15 in the first of the two periods. In this way, the impact of economic change is identified. Source: LFS data and calculations (see Appendix Table 14).

While in 1997-1999 the larger part of the outflow from employment went to unemployment, in 20002002 flows to unemployment and nonparticipation were roughly equal. From 1999 to 2000, however, flows out of employment were predominantly to inactivity, likely because many job-seekers were discouraged and did not seek new jobs. Other reasons for non-activity, such as child-rearing and retirement may also play a role.

The persistence of unemployment has declined but is still substantial. As discussed in the previous chapter, the proportion of unemployed who find themselves in the same situation one year later is very substantial. Still, it has declined from 58 to 46 percent in five years (see Appendix Table 6, middle panel). As Figure 15 shows, the declining persistence of unemployment is due to increasing flows both to 
employment and to inactivity. From 1999 to 2000, and from 2001 to 2002 more than $40 \%$ of the total outflow from unemployment in Latvia left the labor force. This compares with $20 \%$ and $33 \%$ in Estonia (1999-2000 and 2000-2001), 33\% and 27\% in Lithuania (1999-2000 and 2001-2002) 5 . In light of the fact that more than half of those who moved from unemployment to inactivity lost hope of finding a job, discouragement appears to be a problem which needs to be addressed alongside those of long-term and recurrent unemployment.

Figure 15. Outflows from Employment, Unemployment and Inactivity by Destination, 1997 - 2002
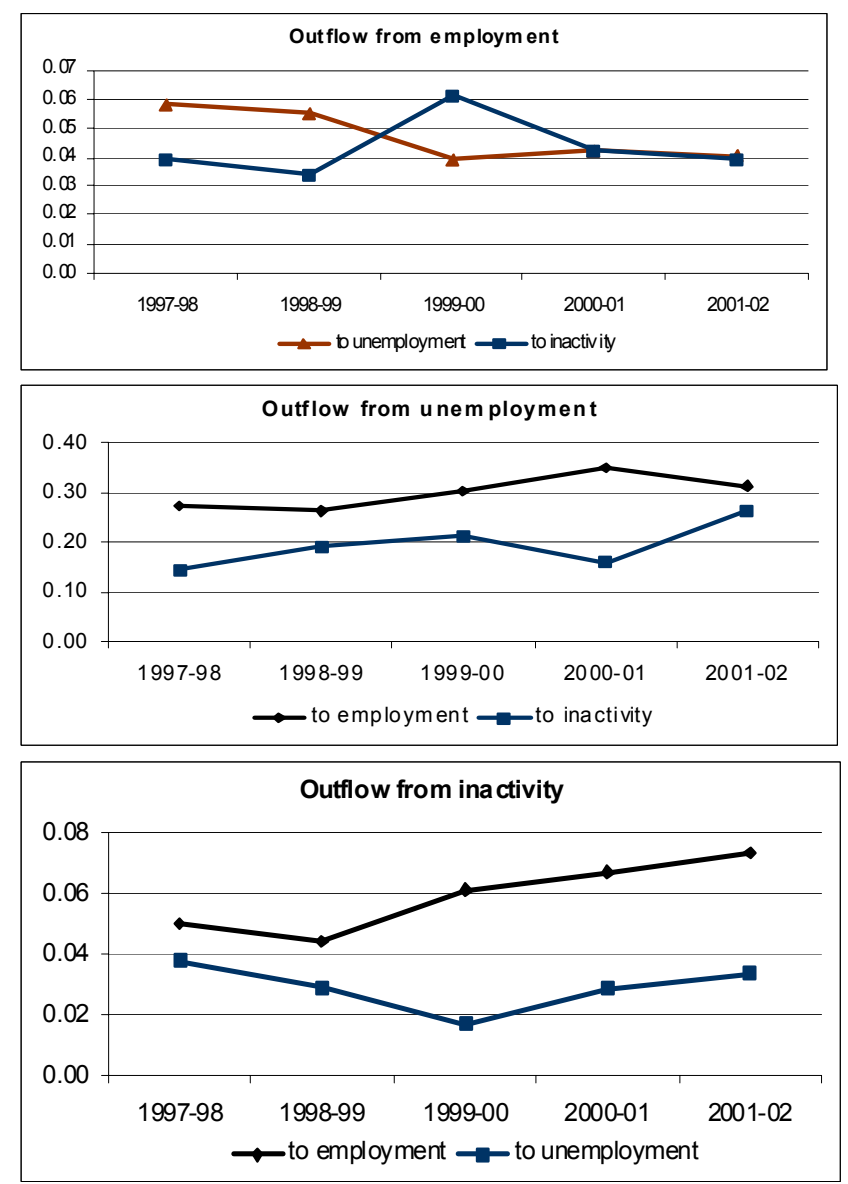

Notes: 1997-2001: flows between Mays of corresponding years; 2001-2002 - annual average.

Flows exclude the impact of migration, mortality, and new entrants who were younger than 15 in the first of the two periods. In this way, the impact of economic change is identified.

Source: Calculations based on LFS data (see Appendix Table 14).

Low mobility between the main sectors ${ }^{6}$. Considering that agricultural employment will likely continue to decline in Latvia, it is disturbing to observe that the recent gross labor flows out of farming were predominantly to non-employment (Appendix Table 15). This trend appears to be increasing over time. Those who found new work in 1997-2001 went predominantly to the service sector, but in 2001-2002 roughly equal numbers went to industry and services.

\footnotetext{
${ }^{5}$ See Hazans (2004b), Figure 6.

6 This and several next paragraphs (until the end of subsection A) draw from OECD (2003a).
} 
Outflows from industry lead mostly to non-employment, but there are also significant flows from industry to service jobs. Flows from industry to services are twice as large as flows in the other direction. Given the size and diversity of the service sector, it is not surprising that this sector has the lowest outflow rates. Recorded outflows from the service sector are almost exclusively to non-employment.

Changes between 1990 and 2000. Appendix Table 16 presents changes in the labor market status of the Latvian population between 1990 and 2000. The most mobile labor market sector appears to be agriculture. Indeed, farmers recorded both the highest probability of making transitions to unemployment and making transitions out of the labor force. Moreover, among those employed in farming in 1990, less than 40 percent were employed ten years later, and only 13.8 percent were found in the same activity.

Among those who worked in industry or services in 1990, the proportion still employed in 2000 is generally a little higher than it was for those farming in 1990. The majority of those employed in both years stayed in the same main sector. According to this measure of mobility, the least mobile group is public service employees.

Empirical evidence shows that there was substantial movement between sectors over the first decade of transition in Latvia. Employment declines in agriculture and industry have given rise to considerable unemployment. Job losers from these sectors frequently find it difficult to compete for jobs with younger labor market entrants. On average, persons, who were in the service sector already in 1990, experienced the best outcomes, while those who were employed in agriculture at that time faced the greatest difficulties.

\section{B. JOB-FINDING PATTERNS}

What makes a successful jobseeker? We now examine factors with the greatest impact on job-finding prospects of the unemployed. For this purpose, multinomial regression analysis is applied to a sample of 1,676 respondents from the LFS 2002 who reported themselves to be unemployed one year prior to the survey. The estimated model predicts the probability of each of three outcomes (employment, unemployment or nonparticipation in 2002) based on the following explanatory variables: education level ( 6 categories), field of education, gender, ethnicity, age, and region of residence. Results are presented in Appendix Table 17, Figures 16 to 18, and Appendix Figures 11 and 12.

Education matters most. While the importance of education for job search is hardly surprising, the magnitude of the effect is impressive. As was shown in the previous section, the mean probability of finding a job in 2001-2002 was 0.31 amongst those unemployed in 2001. For jobseekers with higher or post-secondary education this probability was by 0.20 larger than for an unemployed with basic education of the same age, gender, ethnicity and region of residence (see Figure 16).

Problems with vocational training in Jurmala, Rezekne and Liepaja. The worst outcomes were experienced by a small but statistically significant group of respondents who completed technical secondary education followed by one year of studies leading to a certificate of general secondary education (ISCED ${ }^{7} 4 \mathrm{~A}$ ). This group represented 4.4 percent of those unemployed in the 2001 sample. A more detailed scrutiny shows, however, that it is not general education which must be blamed; rather it is a mismatch between skills provided by technical secondary (ISCED 3C) education in three of the main cities - Jurmala, Liepaja and Rezekne-and market demand. Indeed, a substantial proportion (22\%) of those with ISCED 4A in the 2001 unemployed sample live in these cities. None of the ISCED 4A

\footnotetext{
${ }^{7}$ International Standard Classification of Education
} 
respondents from these cities was employed a year later. Elsewhere the rate of job finding for this education category was 56 percent. A similar picture is found for the much larger group with ISCED 3C education (see Appendix Table 18). On the other hand, an extra year of schooling after vocational training does not appear to have improved job finding performance in the country in general. Perhaps jobseekers in this category are less willing to accept blue-collar jobs than their counterparts with just vocational training.

Figure 16. One-Year Probability of Finding a Job by Age Group and Education Level

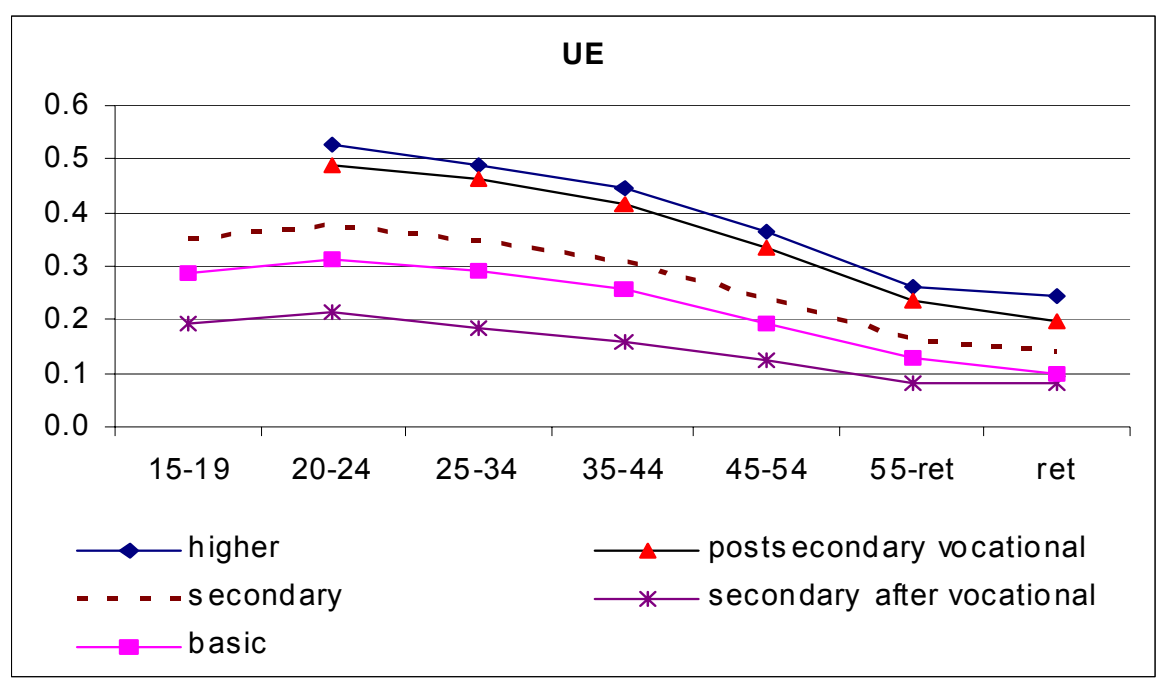

Notes: Secondary includes both general and technical secondary education. Controls for field of education, gender, ethnicity and residence are included. "Ret" stands for retirement age.

Source: Calculations based on LFS 2002.

Technological skills are in high demand. Two broad fields of education which make job search most successful in Latvia are: (i.) transport or communications, and (ii.) engineering, technologies, construction, computer science and mathematics (Figure 17). 
Figure 17. One-Year Probability of Finding a Job by Age Group and Field of Education (controlling for level of education, gender, ethnicity and residence)

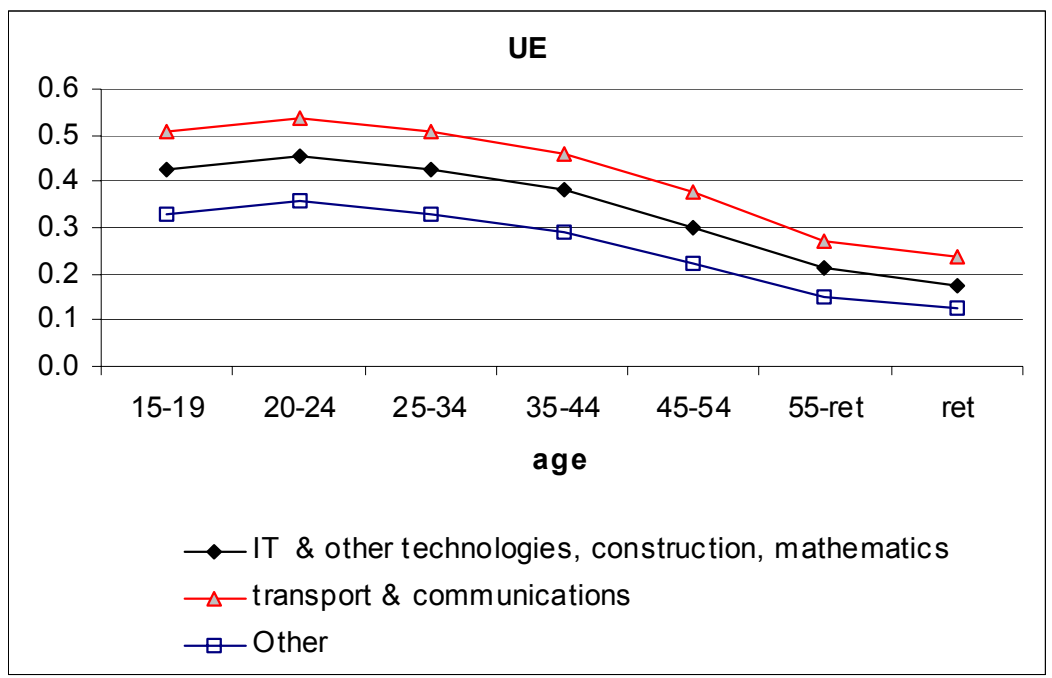

Note: "Ret" stands for retirement age. Source: Calculations based on LFS 2002.

Ethnicity appears to be more important than gender. While unemployed males and females of the same age, education and residence have had virtually equal chances to find a job within a year, for nonLatvians this probability was, on average, 0.08 lower than for otherwise similar Latvians (Figure 18).

Figure 18. One-Year Probability of Finding a Job by Age Group and Ethnicity (controlling for level and field of education, gender, and region)

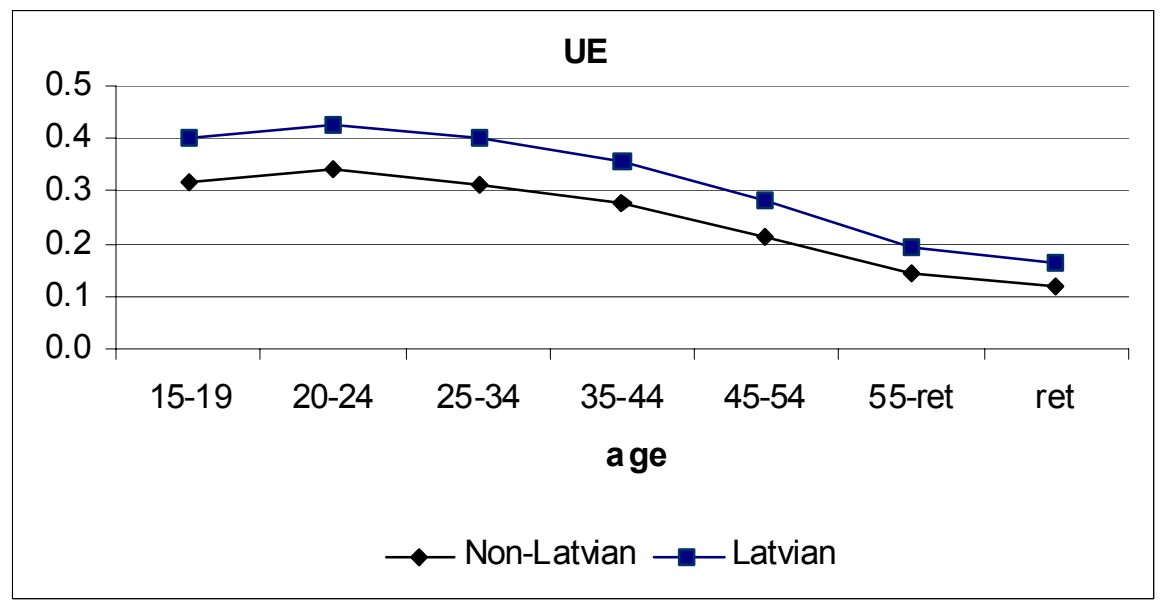

Note: "Ret" stands for retirement age. Source: Calculations based on LFS 2002.

Young people are more likely to find jobs than prime-age jobseekers, while the elderly are trapped in unemployment. As Figures 16 and 18 show, the probability of finding a job falls with age. A very important finding is that, despite relatively high youth unemployment rates, young jobseekers are significantly more successful in job search than those aged 35-44 or 45-54. The group which faces the greatest difficulties is the age group between 55 and retirement age. 
Job creation is low in Latgale, Kurzeme and Zemgale. For the unemployed in Kurzeme or Zemgale the probability of exiting to employment within a year is lower by 0.10 than in Riga region, while for Latgale differential is even larger: -0.14 (see Appendix Figure 11). This again highlights the serious mismatch problems in the labor market of Latgale. Vidzeme, on the other hand, is not different from the Riga region as far as job search prospects are concerned, but jobseekers in Vidzeme more often end up out of the labor force. This is an interesting observation because the stock of discouraged individuals in Vidzeme, although higher than in Riga by most definitions, is lower than the national average (see Appendix Table 11). Appendix Table 20 lists districts with highest and lowest estimated job finding probabilities.

Rural residents are less likely to stay unemployed. Rural residents have significantly higher probabilities of both finding a job within a year and of leaving the labor force than their urban counterparts (see Appendix Figure 12). Consequently, they are less likely to become long-term (or recurrently) unemployed. It is important to notice that of those who move to employment more than a half find jobs in industries and services rather than agriculture. Many of these jobs are located in cities. As discussed in Section B, the role of commuting in overcoming spatial mismatch of skills in Latvia should not be underestimated.

\section{DETERMINANTS OF EXIT FROM EMPLOYMENT}

This section explores factors responsible for labor market transitions in Latvia. The main factors associated with making transitions from jobs to unemployment, and from jobs to nonparticipation, are assessed for individuals who were employed in 2001. Predicted probabilities of each transition type are presented in Figures 20 - 24, and discussed below.

\section{Box 2. 1 Estimating Multivariate Models of Labor Force Transitions}

A multinomial logistic model is estimated using data from the Latvian Labor Force Survey 2002. This model is used to predict the probabilities of three outcomes: employment, unemployment or inactivity in 2002, conditional on being employed one year prior to the interview. A sample of 9,659 is included. The estimated model predicts the probability of each of the three outcomes based on the following explanatory variables: education level (6 categories), gender, ethnicity, age, employment status, occupation, ownership type, sector of economic activity (14 categories), and region of residence. Predicted probabilities are displayed in Figure 19 and Appendix Figures 13 17. Estimation results are presented in Appendix Table 19.

Completed higher education clearly provides protection from unemployment: Figure 20 shows that the higher educated are relatively unlikely to experience job loss. Other things equal, the probability of making a transition from employment to unemployment within a year is just 0.02 for prime-age workers with higher education, two times smaller than the probability for their counterparts with basic education. The probability of exit to inactivity for persons with higher education is lower than amongst those who are less educated, especially for young and elderly workers. On the other hand, those with general or technical secondary and postsecondary vocational education do not have significantly different job loss probabilities from those with basic education. Those who were in their last year of university studies in 2001 have a high estimated probability of being unemployed in 2002. This post-university unemployment, however, is most likely related to labor force entry rather than job losing. 
Figure 19. Predicted Probability of Moving from Employment to Unemployment (E-U) and from Employment to Out of the Labor Force (E-O) Between 2001 and 2002, by Age and Education in 2001
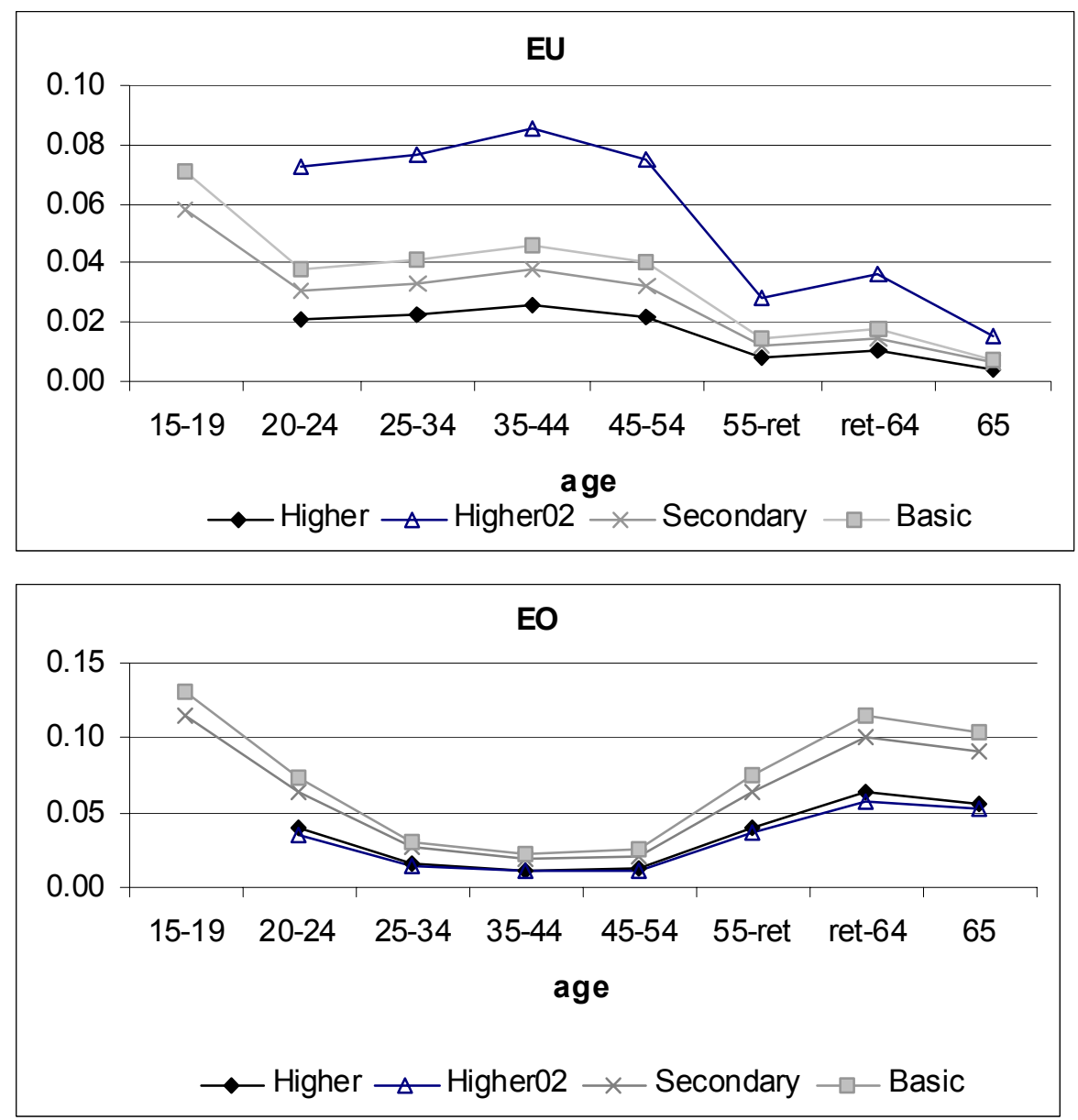

Notes: Gender, ethnicity, employment status, occupation, economic activity and residence are controlled (see Appendix Table 19). Higher02: graduates of higher education institutions in 2002. Postsecondary vocational education merged with general secondary. "Ret" stands for retirement age. Source: Calculations based on LFS 2002.

Gender and ethnicity are not important determinants of the probability of becoming unemployed. However, Appendix Figure 13 shows that females and non-Latvians were significantly more likely to leave the labor force during the 2001-2002 period. With respect to labor force exit, both effects are stronger for youth and the elderly. The difference in probabilities of exiting the labor force is about 0.03 between the sexes and 0.02 between the Latvians and non-Latvians. Note, however, that the 2002 Latvian Labor Force Survey documents that exit from employment to nonparticipation is linked to discouragement in only 7 percent of cases.

Regional effects. Appendix Figure 14 compares the probability of making transitions to unemployment across regions. For prime-age workers in the Riga region, Zemgale, and Kurzeme, the predicted probability of becoming unemployed between 2001 and 2002 is about 0.03 . In Latgale and Vidzeme this probability varies from 0.040 to 0.045 . It is worth noting that, while higher rates of transitions to unemployment are observed in Latgale than in Riga or Zemgale, the difference in unemployment 
transition probabilities is small compared to the difference in unemployment rates between these regions. In Latgale unemployment was 18 percent during this time, while in the Riga and Zemgale regions it was 11 percent.

From the evidence, one may conclude that Latgale suffers primarily from a low rate of job creation and skills mismatch among the long-term unemployed, rather than from a high rate of job destruction. On the other hand, the predicted overall rate of exit from employment (both to unemployment and inactivity) is highest for Vidzeme. Combined with the relatively high proportion of recently discouraged workers there, these findings point towards emerging problems in the Vidzeme labor market. For a summary of districtspecific information on employment transitions, see Appendix Table 21.

The rate of job destruction is significantly higher in cities. About 4 percent of employed urban residents aged 20 to 54 transit from employment to unemployment within a year. In the countryside this proportion is about 2 percent (see Appendix Figure 15). Because some individuals commute to work, differences would be smaller if measured by job location rather than residence. However, information on the location of an individual's job in 2001 is not available in the LFS 2002. Interestingly, there is no difference between urban and rural areas in terms of predicted rates of exit from the labor force.

Labor force transitions by employment status and occupation. Results displayed in Appendix Figure 16 suggest that the self-employed are significantly less likely to become unemployed or to leave the labor force than otherwise similar employees. Individuals in white collar occupations are also relatively unlikely to make transitions to unemployment or to non-participation, in comparison with semiskilled and unskilled manual workers and market and sales workers. Skilled manual workers are similar to other blue collar workers as regards the risk of becoming unemployed, but more similar to white collar workers as far as the probability of leaving the labor force is concerned.

Inter-sectoral differences. There are significant differences between sectors of the economy in terms of job destruction over the 2001-2002 period (see Appendix Figure 17 and Appendix Table 19 for estimation results). The highest rates of job destruction occur in hotels and restaurants, the manufacture of wood products, forestry, and fishing. The lowest rates of job destruction occur in public administration, education, and health care, followed by heavy industry, energy, manufacturing of paper products, printing and publishing.

Previous labor market experience. Finally, everything else equal, employed persons with less than one year of total experience, as well as those who have been registered as unemployed in the past, have significantly lower chances of finding a job within the year. Individuals with less than one year of work experience are also more likely to leave the labor force.

\section{JOB SEARCH METHODS OF THE UNEMPLOYED}

This section explores patterns of job search by unemployed jobseekers. Use is made of several years of data from the Latvian LFS in order to characterize the activities engaged in by unemployed individuals to find new jobs. Information on the nature of job search is of key relevance in designing policies which aid those who have lost their jobs in finding new work.

Main Job Search Techniques Between 1996 and 2000, the LFS provided information only on the main action taken by unemployed individuals to find a job. As can be seen from Figure 20, the proportion of those who indicate registration at SES (State Employment Service) as their main method of job search has been increasing from about one-quarter in 1996 to more than one-third in 1999.Thereafter, use of this method started to decrease, but the SES remains the most popular method of job search. Private employment services play a minor role in job search activities of the unemployed, especially amongst 
females. The proportion of unemployed who mentioned active methods of job search (contacting employers, placing ads in the press or trying to create own business) stayed at approximately 20 percent during 1997-2000. Most of these unemployed individuals contacted employers directly. Only a small portion of the unemployed were trying to start their own business, less than 1 percent of all unemployed. Slightly more than 2 percent placed ads in the press.

In 2001-2002, the LFS permitted the unemployed to indicate more than one method of job search, and this revealed a different picture of how job search is undertaken. As shown in the lower panel of Figure 20, active methods were used by more than 40 percent of the unemployed in 2001 and almost 60 percent in 2002. The SES was used by 30 percent in 2001 and by 36 percent of individuals in 2002 . This includes those who were sent to job training by the SES. Attempts to start up a business were still not popular among the unemployed, at 1.5 percent of all unemployed in 2001 and just 1.1 percent in 2002.

Women are more likely to rely on the State Employment Service. The Latvian LFS shows strong differences between the sexes. Appendix Table 22 provides the results of logit models estimating the impact of various factors on search strategies of the unemployed in 2001-2002. Other things equal, women were significantly less likely than men to use active methods, and significantly more likely than men to the use SES in job search. Gender differences in the predicted probabilities of using active methods of job search were 0.08 in 2002 and 0.11 for SES, somewhat higher than in the previous year. In contrast, ethnic differences in job search strategies were not apparent in 2002, whereas in 2001 minorities were more likely to use active methods and less likely to use SES than Latvians. Most likely, this and other differences between 2002 and 2001 have to do with the fact that 2002 questionnaire offered a more detailed description of active methods of job search, and so led to individuals characterizing their job search activities differently.

The SES does not attract new labor market entrants, the well-educated, or the long-term unemployed. Two target groups of state employment policy-the young unemployed and the long-term unemployed, appear to make relatively little use of its job finding services. Appendix Table 22 shows that young people are less likely to contact the SES in their job search than otherwise similar counterparts of prime age. Similarly, those who have been unemployed for one year or more are less likely to use the SES for job search than those with similar characteristics and shorter elapsed unemployment durations. For a jobseeker aged 20-24 without previous work experience, the probability of contacting the SES in 2002 was $0.30(0.18+0.12)$ smaller than for the unemployed of prime age (after controlling for education, gender, ethnicity and region of residence). In 2001 the effect was weaker but still significant. This clearly suggests that the SES has not become attractive for individuals who do not qualify for unemployment benefits. Given the fact that most of the vacancies reported by the SES do not require higher or even secondary education, it is not surprising that probability of using the SES among the unemployed with secondary education was 5 percent lower than for someone with basic education. In 2002 it was even lower for persons with higher education.

District level unemployment. Regional disparities in unemployment are a key concern to policy makers. Appendix Tables 22 and 23 present the results of models which shed light on regional differences in job search strategies. This permits an indirect means of assessing the performance of local branches of the SES across Latvia's districts.

As far as high unemployment districts are concerned, it appears that jobseekers in Madonas, Balvu, Rezeknes, Daugavpils, Kraslavas, Liepajas and Rezeknes districts are relatively likely to use the SES. Liepajas, Rezeknes, and the Dobeles district are associated with a low probability of using active search methods. At the other end of the spectrum is Aizkraukles district, with a relatively high likelihood of active search and low probability of using the SES. Note that unemployment in Aizkraukle is above average but not as high as in most of the above-mentioned districts. 
Figure 20. Unemployed by Gender and Job Search Methods, 1996-2002
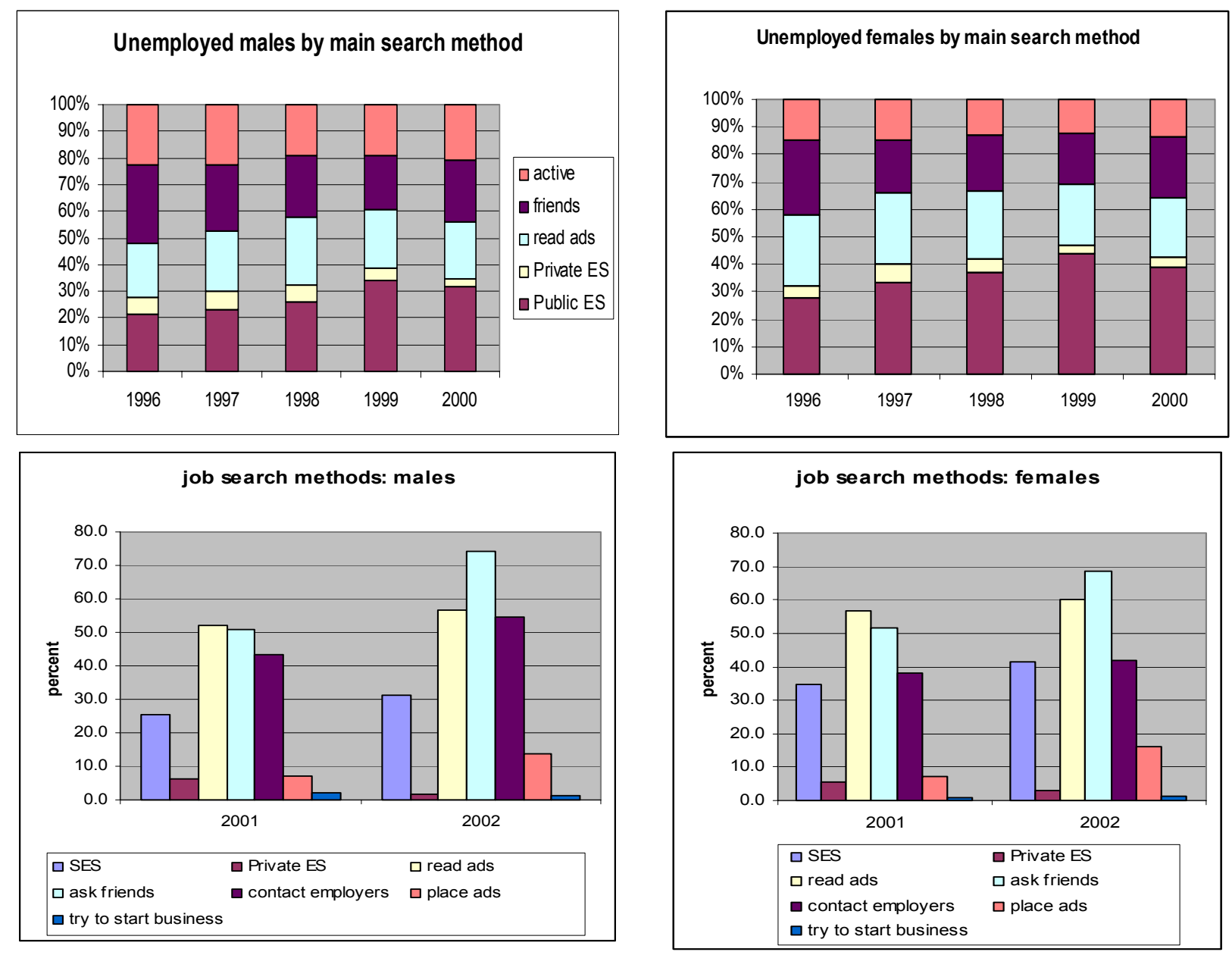

Source: Calculation based on LFS.

\section{E. RElative WAGES}

One of the most important features of a labor market is its wage structure. Are human capital related workers' characteristics - education, general, and firm specific experience - rewarded in Latvia in similar ways as in established market economies? Empirical evidence from other transition countries suggests that returns to education have increased sharply, while returns to experience have decreased compared to the socialist wage setting system. However, the patterns of change and the end result differ across countries, reflecting differences in historical background, social norms, and the industrial structure of the economy.

In the following section, the major factors contributing to wage differences between individuals in Latvia are assessed. Particular attention is focused on differences in wages earned by individuals of differing education levels, gender and ethnic wage differentials, and regional differences in wages. Such an assessment is of great importance in designing policies which target individuals and regions which may have been disadvantaged in the move to a market-based economy. 


\section{Earnings and Education}

The issue of returns to education is of particular interest for Latvia, where the labor force is increasingly well-educated, as shown in Table 3. Earnings functions specifications using LFS 2002 are presented in Appendix Tables 24 and 25. These specifications account both for observable characteristics of individuals, and those of the firms in which they are employed. Appendix Table 24, however, does not control for occupation and plant size, while Appendix Table 25 does. Comparison of these two sets of results helps to understand how human capital is rewarded in the labor market, and also gives useful insights related to gender and ethnic issues. See Box 3 for a discussion. Figure 22 summarizes the findings about current returns to education in the Latvian labor market. Appendix Tables 27 provides means of the variables, used in earnings functions by gender and ethnicity.

Table 3. Full-Time Employees by Educational Attainment, 1997-2002

\begin{tabular}{|c|c|c|c|c|c|c|}
\hline Education & 1997 & 1998 & 1999 & 2000 & 2001 & 2002 \\
\hline Higher & 18.8 & 20.0 & 20.9 & 21.9 & 22.1 & 23.2 \\
\hline Secondary ${ }^{a}$ & 65.6 & 65.9 & 65.2 & 64.3 & 63.3 & 64.4 \\
\hline $\begin{array}{l}\text { Vocational } \\
\text { Basic }\end{array}$ & 3.9 & 3.4 & 3.9 & 3.6 & 3.3 & 1.7 \\
\hline Basic & 10.4 & 9.5 & 9.1 & 9.2 & 10.3 & 9.8 \\
\hline $\begin{array}{l}\text { Less than } \\
\text { Basic }\end{array}$ & 1.4 & 1.2 & 1.0 & 1.0 & 1.1 & 0.8 \\
\hline
\end{tabular}

Box 3 Data and Methodology

The conventional approach to the analysis of wage structure is to estimate an earnings function. This function describes the relationship between the (logarithm of) wages and observable workers' and firms' characteristics. To ensure reliability of the estimated relationship, one needs a representative sample of several thousand employees.

The Latvian LFS provides a large, representative sample of the Latvian population. Until recently, however, wages in the LFS were reported only in broad intervals. This meant, for example, that it was not possible to distinguish between workers who earn 250 and those who earn 400 LVL per month. The highest earnings category included in the questionnaire was "more than 200". Moreover, respondents were asked to report gross rather than net wages, which may also create some confusion for those receiving "envelope wages", who may not know their gross salaries. The Household Budget Survey (HBS), the leading alternative source of labor market information, collects data on wages but has much smaller sample. It does not contain as detailed information about respondents' jobs as the LFS. As well, NORBALT (1999) dataset, which recently became available, contains detailed information on individuals and their wages, but includes less than 2000 observations for which wages are reported or can be derived.

Overall, the LFS appears to be the most appropriate data source to use in analyzing wage structure in Latvia. Since 2002, LFS respondents have been asked to report net wages, and the number of wage intervals has been refined. LFS 2002 data, which contains about 7,000 employees, can therefore provide an accurate data source for estimating earnings functions. To evaluate qualitative changes in the wage structure over time, comparable earnings functions based on the 1997-2002 LFS are estimated. Using this methodology we are also able to compare the market value of education accumulated in the Soviet era and post-Soviet education.

To verify that wage interval information contained in the LFS 2002 indeed provides reliable results, Appendix Table 26 compares several key indicators derived from these data with those obtained from NORBALT (1999) project data. The model specification is restricted by information available for respondents in the NORBALT data, so that job tenure, job location and ownership sector are not controlled for in these benchmark models.

Human capital and earnings. By the year 2002 total returns to higher vs. basic education in the Latvian labor market amounted to 80 percent on average. This implies that, on average, an individual with higher 
education earns $80 \%$ more of what an individual with basic education earns. These returns were significantly larger for females than for males ( 90 vs. 66 percent), for Latvians compared to non-Latvians ( 86 vs. 64 percent) and in the public sector than in the private sector (101 vs. 62 percent). Those working in the countryside have seen somewhat larger payoffs to education than their urban counterparts. A similar pattern is found when returns to higher vs. secondary comprehensive education (just above 50 percent on average) are considered, but in this case the rural - urban gap in returns is also big.

The above figures refer to sub-sample estimates, but when all employees are pooled together, interactions of the higher education dummy with gender, ethnicity and ownership are also significant, and suggest a return 9 to 12 percent. (These models are not reported in the tables, but all factors have the same signs as in models without interaction.) Other things equal, postsecondary vocational education increases earnings by 6 percent compared to secondary; these increases are larger in the countryside than in cities (11 vs. 5 percent). Non-Latvians have smaller returns to comprehensive secondary education than Latvians (10 vs. 20 percent) but larger returns to secondary after vocational and to postsecondary vocational compared to secondary. This seems to reflect some sectoral segregation between ethnicities in the labor market. Returns to secondary and especially secondary vocational education are rather low for all groups, particularly in the countryside.

\section{Box 4. "Access" vs. "Reward" Wage Differentials}

Schooling may affect wages in several ways. More educated employees can be better paid (i.) because they are more productive, (ii.) because employers use educational attainment as a signal of abilities and/or productivity, (iii.) because they work in 'better' firms, or (iv.) because they occupy higher positions in firms.

Wage differentials after accounting for respondent's occupation, ${ }^{8}$ are presented in Appendix Tables 25. Comparing Appendix Tables 24 and 25 allows decomposition of the total payoff to education into two components: (a) returns via access to better firms and/or higher positions, which we refer to as "access" returns, and (b) wage differentials within major groups of occupations and firms, which we refer to as "reward".

About 40 percent of the returns to higher or postsecondary vocational education, and about 27 percent of the gains to secondary (vs. basic) are of the "access" type. This share is smaller in the private companies in comparison to publicly owned ones, and for non-Latvians than for Latvians. Postsecondary vocational and secondary education also provides relatively more "access" and less "reward" for females than for males, and in rural areas compared to cities. The modest total payoff to vocational post-primary" education are on average equally split between "access" and "reward", but for females and those in the countryside "access" dominates. General secondary education on top of vocational increases "reward" more than "access", while higher or postsecondary vocational education compared to general secondary increases "access" more than "reward" (except for the rural employees in the latter case).

The international context. Returns to university vs. secondary education in Latvia are similar to most recent available estimates for Lithuania which refer to year 2000 (although Latvian returns were lower in that year). They are higher than in the most other accession countries and many western countries but lower than e. g., in Ireland (Barrett et al (2000) and Germany (Brücker and Trübswetter (2003)). Returns to secondary education, as in the other two Baltic countries, are low compared to either Central and Eastern European countries or developed market economies. See Appendix Figures 18 and 19.

\footnotetext{
89 major groups according to International Standard Classification of Occupations

${ }^{9}$ ISCED 3C, sometimes called secondary technical
} 


\section{Figure 22. Returns to Education in Latvian Labor Market \\ by Source and Group of Employees, 2002}

(upper panel: general education ladder, lower panel: vocational education ladder)
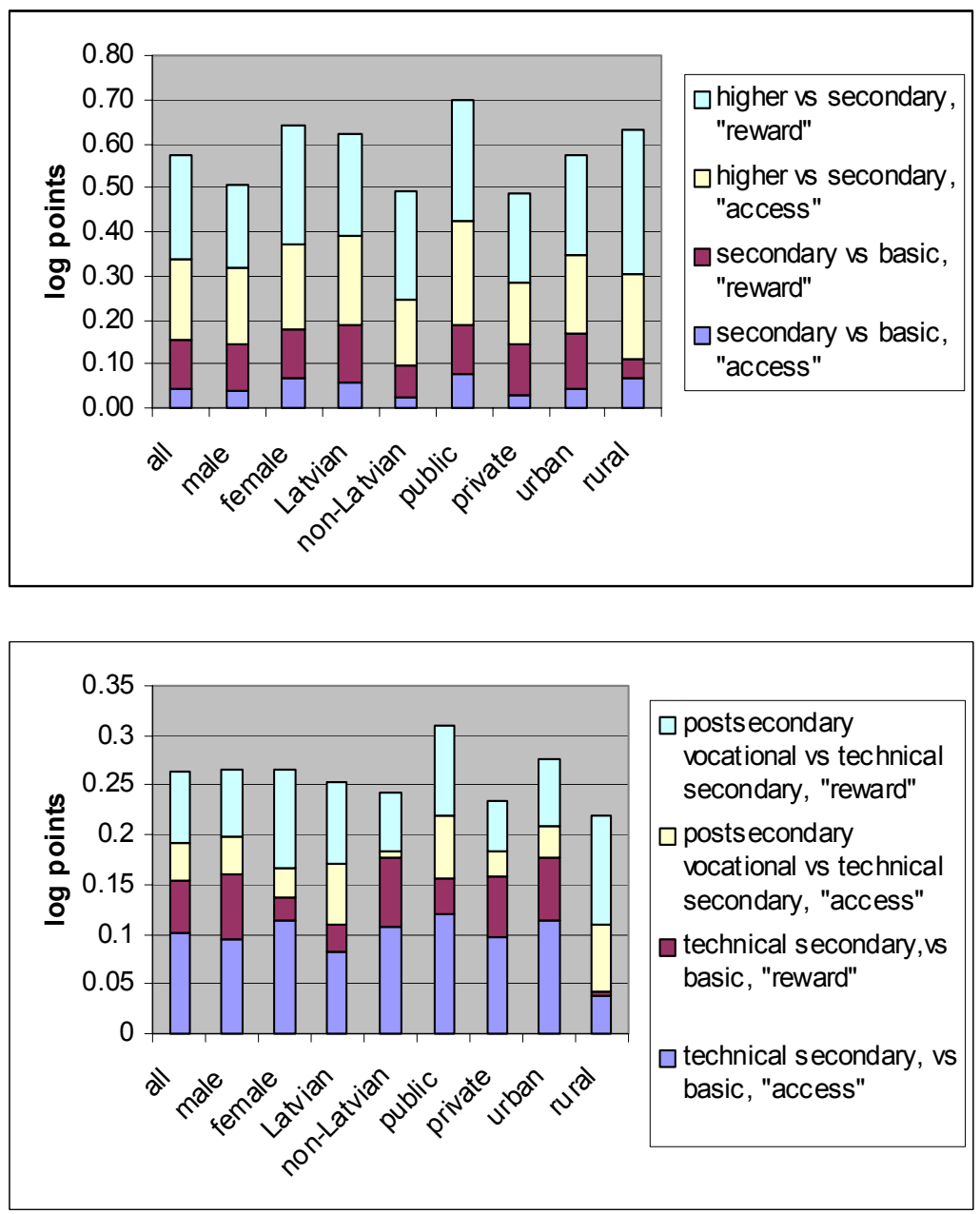

Notes: "Reward" component is returns to education when major group of occupations and firms size are controlled. "Access" component is difference between returns without and with occupation and firm size controls. Returns are numerically smaller than in Appendix Tables 24 and 25 because they are measured in logarithmic points rather than percent to allow decomposition. Professional higher education is not separated from academic. Presented results refer to full-time employees.

Source: Calculation based on LFS data.

\section{Experience and Earnings}

Age-earnings profiles. Cross-sectional age-earnings profiles describe how earnings of individuals differ across cohorts at a given point in time. Age is often taken as a proxy for the length of work experience in studies of returns to human capital. Thus age-earnings profiles give information about how experience is rewarded in the labour market. The typical industrialized country age-earnings profile for men in most education groups is rising up to about age 50-52, after which it decreases. For women it often peaks somewhat earlier. ${ }^{10}$

Compared to the socialist era, a significant decline in returns to experience in most transition countries has been well-documented. The decline is easily attributable to the fact that skills acquired under central

\footnotetext{
${ }^{10}$ See e.g. Ehrenberg and Smith (2003), pp. $277-278$.
} 
planning have lost value during the transition. At the same time, the value of such characteristics as flexibility, adaptability, ability to learn, market-oriented education, foreign language and computer skills - all of which tend to be stronger for younger workers - has increased. As a consequence, both observed and estimated age-earnings profiles (based on available workers' characteristics) in the transition economies tend to peak at a much earlier age than in other industrialized countries (see Hazans (2002) for a more detailed presentation).

The Latvian LFS 2002 can be used to estimate age-earnings profiles separately by gender and education ${ }^{11}$. Results are summarized in Figure 23 (models are not presented here). The male earnings profile peaks at 37 years of age when no postsecondary education is acquired and at $34-35$ otherwise. After this peak, the value of postsecondary vocational education declines with age faster than the value of general secondary education. For females with higher education the peak of the age-earnings profile is 39 years. This profile is flatter than for males. Such a result contrasts with the evidence from Western countries, where age earnings profiles are generally steeper for women. By this measure, women of childbearing age are less disadvantaged in terms of relative wages than in developed market economies. For females with secondary or postsecondary vocational education the advantage of being young reveals itself even more strongly. Age-earnings profiles are remarkably flat. For females with basic education they are downward sloping.

Table 4 confirms that strong position of young employees in the Latvian labor market is a feature shared with the other two Baltic countries. Predicted earnings in the Baltic countries peak not only much earlier than in the West, but also than in the Czech Republic and Slovakia. Earnings peaks in the latter countries are found at $46-47$ years in the private sector and at 53 in the public sector (Juraida (2001), based on 1998 data).

Table 4. Predicted Age of Peak Earnings

\begin{tabular}{llll}
\hline & All employees & Males & Females \\
\hline Estonia, 2000 & 33 & 34 & 31 \\
Latvia, 2002 & 32 & 36 & 30 \\
Lithuania, 2000 & 36 & 34 & 39 \\
\hline
\end{tabular}

Notes: Controls include education, age, ethnicity, ownership sector, sector of economic activity, job location, local unemployment rate. Occupation and marital status are not controlled for. Only full-time employees included. Source: Latvia: Calculations based on LFS data; Estonia and Lithuania: Hazans (2002).

It must be noted that particular age groups might have an advantage in some characteristics not accounted to in the models, so that actual age-earnings profiles can be somewhat different from the predicted ones. Appendix Figure 20 presents actual age-earnings profiles for the Baltic countries.

\footnotetext{
11 In contrast with OECD (2003a), where data allowed distinguishing level but not the shape of the profiles between educational groups.
} 
Figure 23. Estimated Age - Earnings Profiles. Latvia, 2002

(Upper panel: males, lower panel: females)
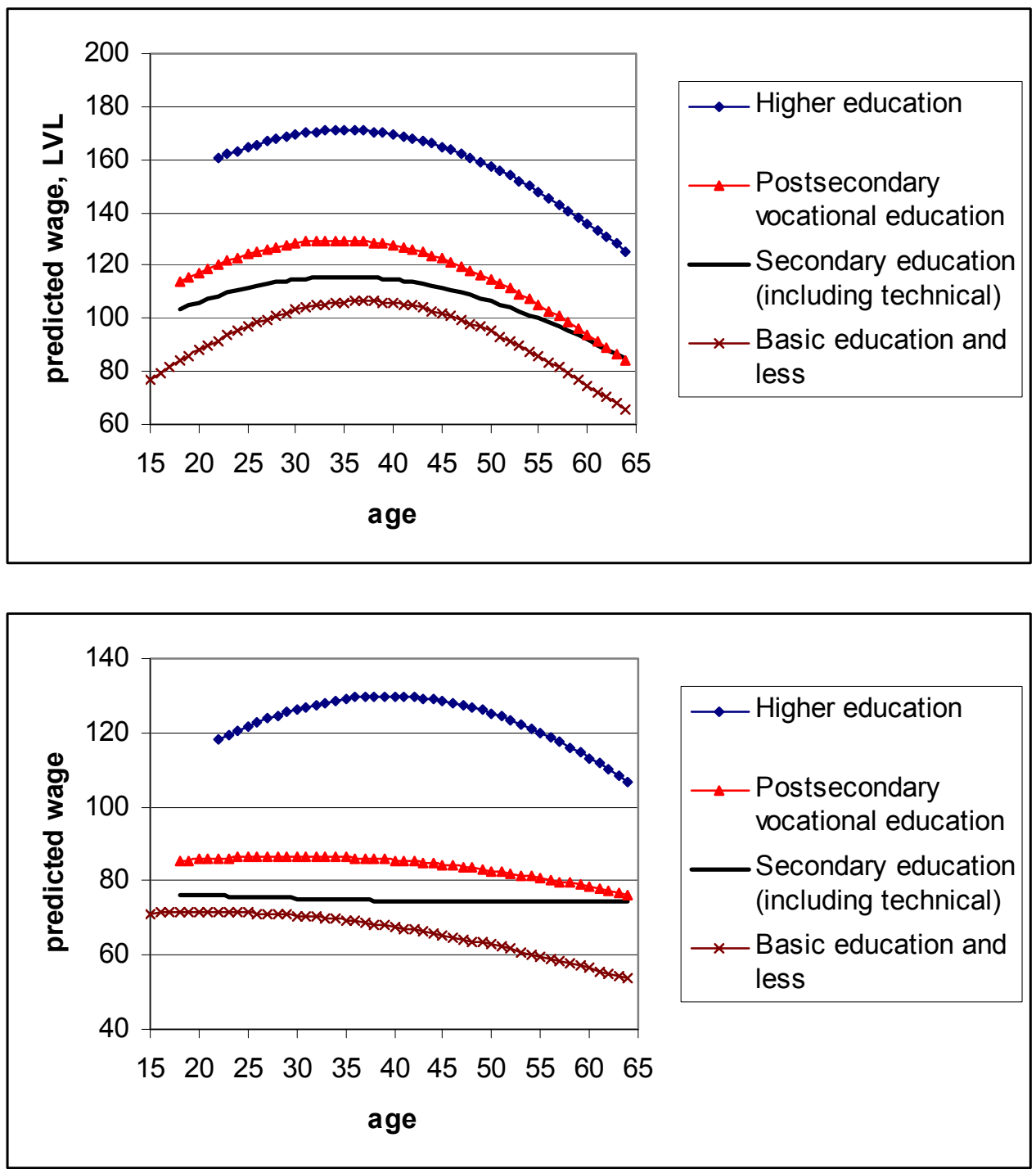

Note: Earnings are measured as after-tax monthly wage at the main job. Source: Calculations based on LFS data.

It matters how long ago one has graduated. Figure 24 relates predicted earnings to "age" of employee's education rather than her/his own age (which is not controlled for in this model). It clearly shows that "new" education has higher market value, especially in the case of university and general secondary education. For males with basic or technical secondary education the effect is weaker. This result is potentially indicative of problems in the vocational education system in Latvia. 
Figure 24. Predicted Wage vs. Vintage of Education. Latvia, 2002

(upper panel: males, lower panel: females)
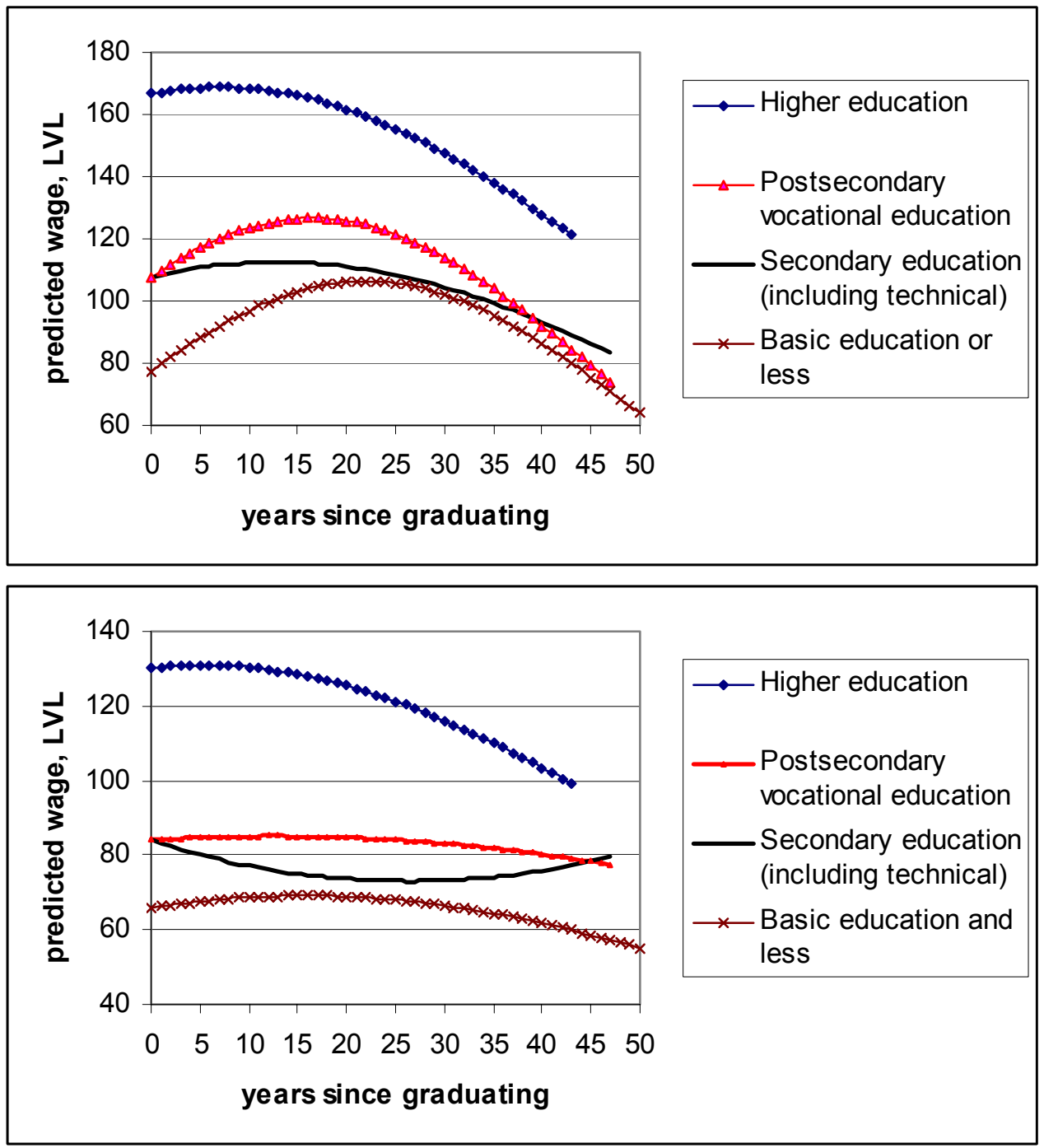

Firm loyalty pays off. Specific experience can be proxied by job tenure - the number of years with the current employer. The average tenure of full-time employees in 2002 was 6 years $(5$ for men and 7 for women). Other things equal, an additional year of tenure increased wages on average by 1.2 percent. Of this increase, 0.7 percent represented a "reward", in the sense that it remains after controlling for occupation and firm size. The remaining 0.5 percent can be attributed to promotions associated with longer tenure. Returns to tenure are higher in Latvia than in Estonia and Lithuania (respectively 0.5 percent and 0.3 percent per year with occupation controls, see OECD (2003a)). It is not clear whether higher returns to tenure are indicative of a somewhat slower pace of change, or are due to stronger trade unions than in neighboring countries. As in Estonia, Russian-speakers are estimated to have higher returns to tenure than ethnic Latvians. Surprisingly, the lowest payoff to tenure is found in the public sector. This is most likely due to the inflow of young well-educated people. During their first year in public sector firms employees earn only 7 percent less than otherwise similar workers with longer tenures.

Temporary workers face uncompensated risks. Another indicator of the strength of employment relationships is the type of contract. Temporary or seasonal workers earn 12 percent less than permanent 
workers with the same characteristics, and 8 percent less when occupation and firm size are also controlled for. This can be explained by the fact that most fixed-term workers have failed to find permanent jobs, and therefore have low reservation wages. Such workers face relatively high unemployment risks as well as low wages. Any compensating wage differentials are overwhelmed by other effects, such as unobservable differences in quality between workers with temporary and permanent jobs. The negative wage differential for temporary workers is larger for ethnic Latvians (-14 percent) than for minority workers (-8 percent).

\section{Wage Discrimination and Segregation}

Gender pay gaps. Wage discrimination refers to a situation in which equally productive individuals are paid different wages due to some characteristic (like gender, or ethnicity) that is unrelated with productivity. The issue of the gender pay gap has been a focus of research and policy for both for transition and developed market economies. On average, Latvian females earn about 80 percent of males' earnings. This ratio, the same as in Poland, lies between those of Estonia and Lithuania, and is higher than in Czech Republic (see Appendix Table 28). While at the national level this ratio has been broadly stable since 1997 (see Appendix Table 29), it varies significantly across occupations (see Appendix Table 29), industries and regions. For example, in 2001 women earned 99.5 percent on men's earnings in public administration but just 57 percent in financial intermediation. The gender pay gap tends to be wider in higher wage regions of Latvia (see Appendix Figure 21).

Occupational segregation. The degree of industrial and occupational segregation in a country can be measured by a dissimilarity index (see Tables 5 and 6). This index is a calculation of the minimum proportion of females who would have to change occupations (industries) in order to make the distributions of males and females equal. Thus, higher values of the dissimilarity index suggest higher degrees of segregation. According to this index, Latvia is not very different from Estonia. As far as occupations are concerned, it is not very different from Poland or Hungary. Latvia has somewhat higher occupational segregation than Lithuania or the Czech Republic.

Table 5. Occupational and Sectoral Segregation of Full-Time Employees by Gender and Ethnicity in the Baltic Countries, 2000: Dissimilarity Index ${ }^{\text {a }}$

\begin{tabular}{lccc}
\hline \multicolumn{1}{c}{ Segregation } & Estonia & Latvia & Lithuania \\
\hline Genders by occupations $^{\mathrm{b}}$ & 0.41 & 0.38 & 0.35 \\
Genders by economic activities $^{\mathrm{c}}$ & 0.31 & 0.31 & 0.29 \\
Ethnic groups by occupations $^{\mathrm{b}}$ & 0.15 & 0.11 & 0.29 \\
Ethnic groups by economic activities $^{\mathrm{c}}$ & 0.26 & 0.21 & 0.14
\end{tabular}

Notes: Dissimilarity index is a number between 0 and 1 , with 0 indicating equal distribution of genders (or ethnic groups) among occupations, and 1 indicating complete segregation. It shows the minimal proportion of females which have to change occupations in order to make occupational distributions of females and males equal. ${ }^{b}$ Nine major groups of occupations according to ISCO $88 .^{\mathrm{c}} 15$ sectors $(\mathrm{A}, \mathrm{B}, \ldots, \mathrm{O})$ according to NACE.

Sources: Calculation based on LFS data.

Can segregation, human capital, or the longer hours worked by men explain inequality in pay between the sexes? While females are better educated and over-represented among professionals (see Appendix Table 27), a well-paid occupation, they are heavily concentrated in education and health care. These two sectors are found at the bottom of the wage ranking. 
Table 6. Occupational Segregationa of Employees by Gender in the Baltic Countries (1997 - 2000) and Central Europe (1997-1999)

\begin{tabular}{lcccl}
\hline & $\mathbf{1 9 9 7}$ & $\mathbf{1 9 9 8}$ & $\mathbf{1 9 9 9}$ & $\mathbf{2 0 0 0}$ \\
\hline Estonia & 0.432 & 0.423 & 0.411 & 0.408 \\
Latvia & 0.406 & 0.407 & 0.407 & 0.409 \\
Lithuania & 0.335 & 0.339 & 0.312 & n. a. \\
Poland, public sector & 0.468 & 0.458 & 0.465 & n. a. \\
Poland, private sector & 0.362 & 0.345 & 0.342 & \\
Czech R. & 0.340 & 0.340 & 0.375 & n. a. \\
Hungary & 0.390 & 0.380 & 0.390 & n. a. \\
\hline
\end{tabular}

Notes: ${ }^{a}$ Dissimilarity index by nine major groups of occupations according to ISCO 88. Sources: Enterprise census results for Latvia and Lithuania, LFS results for Estonia, and own calculations; Laxton (2001) for Poland, Czech Republic and Hungary.

Estimated earnings functions, presented in Appendix Tables 24, 25, and 26, predict about 25 percent lower net wage for women than for otherwise similar men after the impact of other observable factors is accounted for. This gap stays almost unchanged if occupation and/or working hours are controlled for, suggesting that segregation and working hours are unlikely to explain the unequal gender pay.

Table 7 puts the gender wage gap in an international context. Although the gender pay gap in Latvia has increased substantially between 2000 and 2002, it is still not large in comparison with other countries. (Brainerd (2000) and Newell and Reilly (2001) provide evidence that in most of the transition countries the evolution of the gender gap has been slow, so comparing results from different years makes some sense.)

Table 7. Ceteris paribus ${ }^{\#}$ Female - Male Wage Ratio (percent).

Latvia (2000 and 2002), Estonia and Lithuania (2000), Selected Central European (1992-98), Former Soviet Union (1995-96) and OECD (1983-97) Countries.

\begin{tabular}{|c|c|c|c|c|c|c|c|}
\hline $\begin{array}{l}\text { he Baltic } \\
\text { States }{ }^{\text {a }}\end{array}$ & $\begin{array}{l}\text { Wage } \\
\text { Ratio }\end{array}$ & $\begin{array}{l}\text { CEE } \\
\text { Countries }\end{array}$ & $\begin{array}{l}\text { Wage } \\
\text { Ratio }\end{array}$ & $\begin{array}{l}\text { Former SU } \\
\text { Countries }\end{array}$ & $\begin{array}{l}\text { Wage } \\
\text { Ratio }\end{array}$ & $\begin{array}{l}\text { OECD } \\
\text { Countries }\end{array}$ & $\begin{array}{l}\text { Wage } \\
\text { ratio }\end{array}$ \\
\hline \multicolumn{4}{|c|}{ Occupation controls included } & \multicolumn{4}{|c|}{ Occupation controls included } \\
\hline Estonia & 79 & Bulgaria & 78 & Kazakhstan & 76 & $\mathrm{UK}^{\mathrm{d}}$ & 61 \\
\hline Lithuania & 84 & Hungary & 81 & Uzbekistan & 77 & Canada ${ }^{\mathrm{d}}$ & 68 \\
\hline Latvia, $2000^{\mathrm{e}}$ & 84 & Poland & 84 & Russia & 79 & $\mathrm{US}^{\mathrm{d}}$ & 70 \\
\hline Latvia, $2001^{\mathrm{e}}$ & 83 & Yugoslavia & 87 & Ukraine & 82 & Ireland ${ }^{\mathrm{d}}$ & 74 \\
\hline Latvia, $2002^{\mathrm{e}}$ & 76 & & & & & Germany $1^{\mathrm{d}}$ & 82 \\
\hline \multicolumn{4}{|c|}{ Occupation controls not included } & & & Germany $2^{f}$ & 76 \\
\hline Estonia/private & 82 & Czech R./private & 77 & & & Germany $3^{g}$ & 77 \\
\hline Estonia/public & 76 & Czech R./public & 86 & & & Netherlands ${ }^{d}$ & 83 \\
\hline Lithuania/private & 84 & Slovakia./private & 82 & & & & \\
\hline Lithuania/public & 85 & Slovakia/public & 93 & & & & \\
\hline
\end{tabular}

Latvia:

2000, private ${ }^{\mathrm{e}} \quad 87$

2000 , public ${ }^{\mathrm{e}} \quad 83$

2002, private $^{\mathrm{e}} \quad 77$

2002, public $^{\mathrm{e}} \quad 74$

Notes: ${ }^{\#}$ Other things, including sector of economic activity, being equal. All ratios are significantly different from 1 at 0.01 significance level. The estimates for Latvia presented here for 2000 - 2002 are based on interval data. Those for 2002 are consistent with the results derived from NORBALT (1999) dataset with self-reported wages.

Sources: ${ }^{a}$ OECD (2003a) and own calculations. ${ }^{b}$ Hungary (1992) - Pailhé (2000); Bulgaria (1995), Poland (1996), Yugoslavia (1996) - Newell and Reilly (2001); Czech R. and Slovakia (1998) - Juraida (2001). ${ }^{\mathrm{c}}$ Newell and Reilly (2001).

${ }^{\mathrm{d}}$ UK (1983-89), Canada (1986), Ireland (1988-89), West Germany (1986-91), Netherlands (1987-90) - Blanchflower and Oswald (1994); US (1990) - Hellerstein et al (1999); ' Based on survey interval regression;

f,$^{\mathrm{g}}$ - West and East Germany, 1996-97 - Brucker and Trubswetter (2003). 
While the ceteris paribus gender age ratio presented in the Table 7 compares men and women with similar human capital and job characteristics, a more adequate approach to measuring overall gender inequality in earnings must account for the fact that females' average characteristics are indeed different from males'. Such an approach was developed by Oaxaca (1973) and Oaxaca and Ransom (1988) and has been widely used since in the literature. As noted before, Latvian women are, on average, better educated than men; they also have longer tenure and total work experience (see Appendix Table 27). Moreover, returns to education are higher for women (see Appendix Tables 24 and 25, columns (5) and (6)). Taking this into account, Table 8 shows that in 2002 about 60 percent of entire wage gap in Latvia has to be ascribed to discrimination or unobserved characteristics ${ }^{12}$. Another 15 percent is due to occupational segregation within major occupational groups. Productivity differential absorbs just a quarter of the gender wage gap. In Estonia and Lithuania (2000), however, almost the whole pay gap remains unexplained. In this respect, Lithuania and Estonia are similar to the US, UK and Germany (see Kunze (2000)), while the Latvian situation is closer to that of Central European countries. According to Pailhé (2000) and Juraida (2001) productivity differences between men and women explain from onethird to one-half of the total pay gap in Central European countries.

Table 8. Gross male - female wage differentials ${ }^{\mathrm{a}}$ and productivity differentials ${ }^{\mathrm{b}}$. Percent

\begin{tabular}{lccc}
\hline & $\begin{array}{c}\text { Gross wage } \\
\text { differential }\end{array}$ & $\begin{array}{c}\text { Productivity differential } \\
\text { (without occupation controls) }\end{array}$ & $\begin{array}{c}\text { Productivity differential } \\
\text { (with occupation } \\
\text { controls) }\end{array}$ \\
\hline Estonia, 2000 & 24 & 3 & 5 \\
Latvia, 2000 & 19 & 7 & 10 \\
Latvia, 2002 & 31 & 8 & 12 \\
Lithuania, 2000 & 14 & -1 & 0 \\
\hline
\end{tabular}

Notes: ${ }^{\text {a }}$ These differentials, according to conventional methodology of decomposition, are calculated as $\exp (d)-1$, where $d$ is the difference between mean log net monthly wages of males and females;

${ }^{\mathrm{b}}$ Differential in (geometric) mean predicted wages of males and females, using earnings function estimated over pooled sample without gender dummy; known also as explained gender pay gap. ${ }^{\mathrm{c}}$ Sector of economic activity is controlled for. Males' and females' earnings functions used to derive estimates in columns 2 and 3 are partly presented in Appendix Tables 24 and 25. Sources: Calculations based on LFS data.

Table 9. Patterns of Industrial Segregation by Ethnicity in the Baltic States, 2000

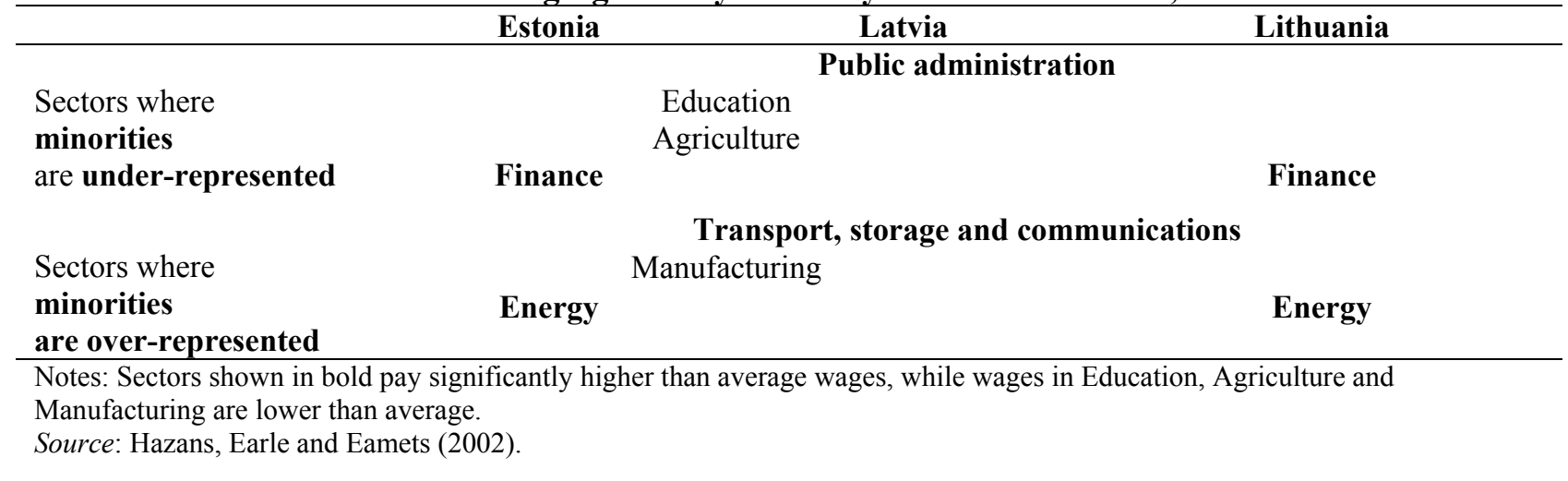

\footnotetext{
${ }^{12}$ Controlling also for hours worked would narrow the unexplained gap by only 1 percentage point.
} 


\section{Box 5. Ethnicity, Earnings, and Occupational Segregation}

An issue of great political importance in the Baltic countries is that of discrimination against ethnic minorities.

A critical problem in evaluating this issue is that the available data do not contain information on state language skills, which are likely to be correlated with ethnicity. Bearing this in mind, the average differentials are sizable nonetheless. According to LFS 2002 data, in which ethnicity is self-reported, ethnic Latvians' average net earnings were 10 percent higher than those of other ethnic groups (mainly Russians). This can be compared to a 16 percent differential found in Estonia and 9 percent - in Lithuania (using 2000 data).

Despite the low levels of occupational segregation amongst ethnic groups in Latvia, segregation of ethnic groups by economic activities is substantial. According to a dissimilarity index measure of segregation, at 0.21 segregation in Latvia is less strong than in Estonia but larger than in Lithuania. Table 8 summarizes the most pronounced horizontal segregation patterns. All three countries having a relatively low share of minority employees in public administration, and relatively high share in transport and communications (Appendix Table 27 provides details for Latvia). In contrast with occupational segregation, there is no clear evidence that minorities are concentrated in lowwage sectors. Segregation with respect to ownership sector is found only in Latvia, where 35 percent of nonLatvians and 49 percent of Latvians are employed in the public sector.13 Finally, in all three countries a much larger proportion of minorities than of native employees have the advantage of working in the capital city, where the wages are higher.

It is of policy interest to compare gross ethnic wage differentials and unexplained wage differentials with those experienced in the other Baltic countries (see Table 10 and Appendix Table 31). The gross differential and unexplained gap are largest in Estonia, while the Latvian and Lithuanian gaps are comparatively modest. Only in Lithuania can part of the gross ethnic wage differential be explained by observed employee characteristics, and this part is small when occupation is not controlled for. After accounting for major occupational groups and firm size the unexplained gap narrows by 30 percent in Estonia, by more than 40 percent in Lithuania, and fully disappears in Latvia. This suggests that occupational segregation is responsible for a substantial part of the ethnicity effect on earnings. The residual gap in Estonia and Lithuania has to be ascribed to unobserved characteristics and finer occupational segregation than accounted for here.

Table 10. Gross wage Differentials ${ }^{a}$ and productivity Differentials ${ }^{b}$ between Native Employees and Ethnic Minorities. Baltic Countries, 2000 - 2002. Percent Gross wage Productivity differential differential (without occupation controls ${ }^{\mathrm{c}}$ )

\begin{tabular}{lcc}
\hline Estonia (2000) & 12.2 & -4.6 \\
Latvia (2000) & 3.3 & -2.6 \\
Latvia (2002) & 10.2 & -2.1 \\
Lithuania (2000) & 8.7 & 1.8
\end{tabular}

Notes: ${ }^{a}$ These differentials are based on mean log wages of the two groups rather than mean wages. ${ }^{b}$ Differential in (geometric) mean predicted wages of males and females, using earning function estimated over pooled sample without ethnic dummy; known also as explained pay gap. ${ }^{c}$ Sector of economic activity is controlled for. Sources: Calculations based on LFS data.

\section{Local unemployment and wages}

One of the commonly used methods of measuring labor market flexibility is to estimate so called wage curve: the responsiveness of wages to regional unemployment rates at job locations (see Blanchflower and Osvald (1994). This methodology involves calculating the relationship between wages and unemployment levels, referred to as elasticity. This calculation measures the responsiveness of wages due

\footnotetext{
${ }^{13}$ Only hired employees are considered in this analysis.
} 
to a 1 percent increase in unemployment. Thus wage elasticity of -.3 implies that an increase of 1 percent (not a percentage point!) in unemployment is associated with a .3 percent decrease in wages. The advantage of elasticity-based measures is that they are unit-free, and thus readily comparable across samples and countries.

While for most of the established market economies the wage elasticity with respect to local unemployment rates is around -0.1 after controlling for worker characteristics, evidence from transition countries is more diverse. Higher than flexibility than in Western countries was found in some former Communist countries, while in others no wage curve was discovered at all. OECD (2003a, Tables A3.1A3.2), using year 2000 LFS data, finds statistically significant wage curves in Estonia and Latvia but not in Lithuania; Hazans et al (2002) compare 1999 and 2000 results. The estimated elasticities in Estonia were -0.24 in 1999 and -0.15 in 2000, and in Latvia were -0.11 in 1999 and -0.05 in 2000 . Thus, during the 1999 crisis the impact of unemployment on wages was twice as strong as in 2000. Men's wages were much more sensitive to local unemployment rates than women's.

Results presented in Appendix Tables 24 and 25 confirm a very significant effect of local unemployment on wages across the 33 NUTS 4 regions ${ }^{14}$ of Latvia. We find an elasticity of wages with respect to unemployment of -0.19 on average. Again there are substantial differences between the sexes. For men it is -0.24 , while for women just -0.13 . Private sector wages are more responsive to local labor market conditions than those in the public sector, with respective elasticities of -0.26 and -0.15 respectively. Finally, earnings of employees with higher education are significantly less sensitive to local unemployment rates than are earnings of less educated individuals. Estimated elasticities are -0.08 with and -0.20 without higher education. These estimates are derived from models (not shown in the tables) with interaction terms.

Numerical values of the elasticity of wages with respect to unemployment are higher than found in the OECD (2003a) study for several reasons. One potential cause of difference is the methodology applied. ${ }^{15}$ Still, some of the difference is attributable to the fact that labor market flexibility has somewhat increased since 2000, the year of the OECD (2003a) data. These issues are discussed in more detail below.

Regional effects. Earnings functions may also shed light on the degree of geographical segmentation of labor markets due to barriers to mobility. The inclusion of regional variables representing the capital city, the capital district, port city, small city, and rural area in the earnings function generally have highly significant effects. These estimates are shown in Appendix Tables 24 and 25. In the year 2002, an employee working in a rural area earned 10 percent less than an otherwise similar employee in a small city. Employees working in Riga earned 37 percent more than those working in smaller towns (Appendix Table 24, column (2)). Working in Jurmala, Riga district, Ventspils or Liepaja also increases earnings significantly, although less than working in Riga. Employees in Daugavpils, however, earned 11 percent less than in small cities (other things equal). The wage differential associated with working in Riga is very big by international standards. In Estonia, Lithuania and Poland the wage premium associated with working in the capital city is just above 20 percent (see Table A3.1 in OECD (2003a); and Newell (2001)).

A substantial part of the effect of job location on wages can be explained by differences in unemployment rates. When local unemployment (measured by the 33 NUTS 4 regions) is controlled for, the wage advantage of Riga, Riga district and Ventspils is strongly reduced (compare columns (4) and (2) of

\footnotetext{
${ }^{14}$ Registered unemployment rates (at the end of previous year) were used because they are more reliable for these small regions; LFS-based rates, however, give similar results.

${ }^{15}$ Interval regression used here is more likely to give unbiased estimates than wage imputation used by OECD.
} 
Appendix Table 24). However, differentials associated with Jurmala, Liepaja and Daugavpils are almost unchanged from specifications which do not account for local unemployment, suggesting region-specific effects dominate those of local unemployment for people in these towns.

Some of the regional effects depend on gender or ethnicity. The advantage of working in Jurmala, Liepaja or Ventspils is much more pronounced for men than for women. The effects of working in Riga district and Liepaja on non-Latvians' earnings are two times larger than on Latvians' earnings, but it is the other way around in Jurmala. Finally, except for Ventspils and Daugavpils, all above-mentioned location effects on earnings are almost completely concentrated in the private sector.

The further from Riga, the lower are wages. Another way to look at regional wage effects is to link them with the distance between job location and Riga. It turns out that, Ventspils and Liepaja aside, every 10 kilometers of distance from Riga reduce wages by 1.8 percent for workers without higher education, and by 1.2 percent for employees with higher education. This model is estimated using LFS 2001 data, and is not shown. The main effect is significant at 0.001 level, interaction with higher education - at 0.05 level. All described regional effects remain almost unchanged when (the major group of) occupation is controlled for. In our terminology, these are pure "reward" rather than "access" effects.

Small firms pay less. Since 2002 the Latvian LFS has included a question on the number of employees in the local unit where the respondent actually works. This indicator, usually referred to as plant size, is obviously correlated with firm size. Small firms cannot have big plants. All else equal, an individual working in an establishment with 50 or more employees earns $15 \%$ more than an otherwise similar employee in a small unit with 1 to 10 workers. The 'small firm' effect is more pronounced in rural areas and among non-Latvians (see Appendix Table 25). As in other industrialized countries, the larger the firm, the higher are wages. The size of the effect is somewhat larger than in Lithuania and smaller than in Estonia. Still, the general structure is similar in all three countries, with larger differences between the public and private sectors in Estonia (see Appendix Table 31).

\section{EVOLUTION OF THE KEY INDICATORS, 1997-2002}

In conclusion, we examine the changes which occurred between 1997 and 2002 in some key indicators of Latvia's labor market: the impact of education, gender, ethnicity and region on labor force participation, unemployment risk and earnings. Both 1997 and 2002 were years of strong growth of Latvian economy, therefore the comparison is not likely to be distorted by cyclical factors.

Education effects increased. Appendix Tables 32-34 show that for men education effects on earnings, participation, and unemployment risk have in general become stronger. Wage differential associated with higher education (as compared to less than secondary) has increased from 61 percent to 69 percent; moreover, both marginal effects of higher vs. secondary and secondary vs. basic education have also widened $^{16 .}$ In 2002 probability to be unemployed for a man with (general or technical) secondary education or basic vocational education was by 7 to 8 percentage points lower than for otherwise similar man with basic education, while in 1997 the difference was just 2 percentage points (the change is even bigger in relative terms, because the unemployment rate dropped from 15 to 13 percent). This evidence for improved quality of vocational education is reinforced by the fact that effect of basic or postsecondary vocational qualification on men's probability to participate in the labor force has also increased (by 3 and

\footnotetext{
${ }^{16}$ Categorization of secondary education in LFS 2001-2002 is not exactly the same as in previous years, but this conclusion follows from models where all types of secondary education are merged (not shown). Notice also that 2002 differentials refer to net earnings, and they will further increase somewhat when translated to gross wage differentials.
} 
2 percentage points respectively). Notice, however, that basic vocational education still does not have significant effect on men's or women's earnings. For women, education had stronger effect on earnings and activity in 2002 than it 1997, but effect on unemployment risk was somewhat weaker.

Gender participation gap unchanged, wage gap widening. Other things equal, unemployment risk for females was not significantly different than for males both in 1997 and in 2002 (Appendix Table 34). By contrast, a female earned 17 percent less than otherwise similar ${ }^{17}$ man in 1997, and this gap has been extended to 25 percent in 2002 (Appendix Table 32). As shown in Table 7, this increase of gender wage differential actually took place between 2000 and 2002. Men thus have benefited more than women from the strong wage growth during this period. Ceteris paribus male - female differential in probability to participate in the labor force stayed almost unchanged: 9.5 percentage points in 1997, 10.0 percentage points in 2002 (logit models of participation for pooled men-women samples are not shown in this paper).

Persistent ethnic effects. In both years non-Latvians were less likely to participate in the labor force than otherwise similar Latvians, the difference stayed unchanged at 3 percentage points for men but increased from 5 to 7 percentage points for women (Appendix Table 33). For those non-Latvians in the labor force, chances to find themselves unemployed in 2002 were by 3 percentage points higher than for otherwise similar Latvians; the difference has slightly decreased since 1997 for men but increased for women (Appendix Table 34). Finally, net earnings of non-Latvian worker in 2002 were 13 percent below that of Latvian worker with the same education, age and gender, working in the same industry and region; in 1997 the ethnic pay gap (in gross earnings) was 10 percent for men and 6.5 percent for women. All above mentioned ethnic effects are statistically very significant. It is important to notice, however, that these results cannot be readily interpreted as an evidence for discrimination since they are based on data where information on respondent's Latvian language skills is missing. A further research is needed in this direction.

Young people are less active but more successful in labor market than 5 years ago. Predicted age activity profiles derived from models presented in Appendix Table 33 are shown in Appendix Figure 22. Predicted participation rates have decreased significantly for young men and women, as well as men aged 35-44; smaller decrease in activity is found for women aged 25-44. On the other hand, women aged 55-64 and men aged 64-74 have become more active, other things equal. Figure 25 displays evolution of the estimated age - unemployment risk profile. When all economically active population is considered, risk of unemployment has declined compared with 1997 for all age groups except 35-44 years old. If only people with work experience are included in the analysis, then a decline in the unemployment risk is found for 25-34 and 45-64 years old. An important finding is that when new entrants are excluded or controlled for, risk for the youth is not higher than for prime age workers.

The most significant changes have occurred in the age - earnings profiles. Here we focus on the "average" profiles (separate profiles for each education level for 2002 were shown in Figure 23). Models presented in Appendix Table 32 imply that estimated age of peak earnings decreased dramatically for both genders: from 40 to 30 years for men and from 44 to 28 years for women. The shape of men's profile has changed very little for ages until 40 years but afterwards declines much steeper in 2002 than 1997. Females' profile has become slightly steeper in the range from 40 to 65 year and much flatter in the range from 15 to 40 years. In other words, returns to experience declined for males older than 40 and females younger than 40 .

In sum, compared to 1997, youth has become less active in 2002, but active young people face lower unemployment risk than 5 years ago, and their position in earnings rankings has improved as well.

\footnotetext{
${ }^{17}$ Occupation is not controlled for.
} 
Figure 25. Estimated Age - Unemployment Risk Profiles. Latvia, 1997 and 2002
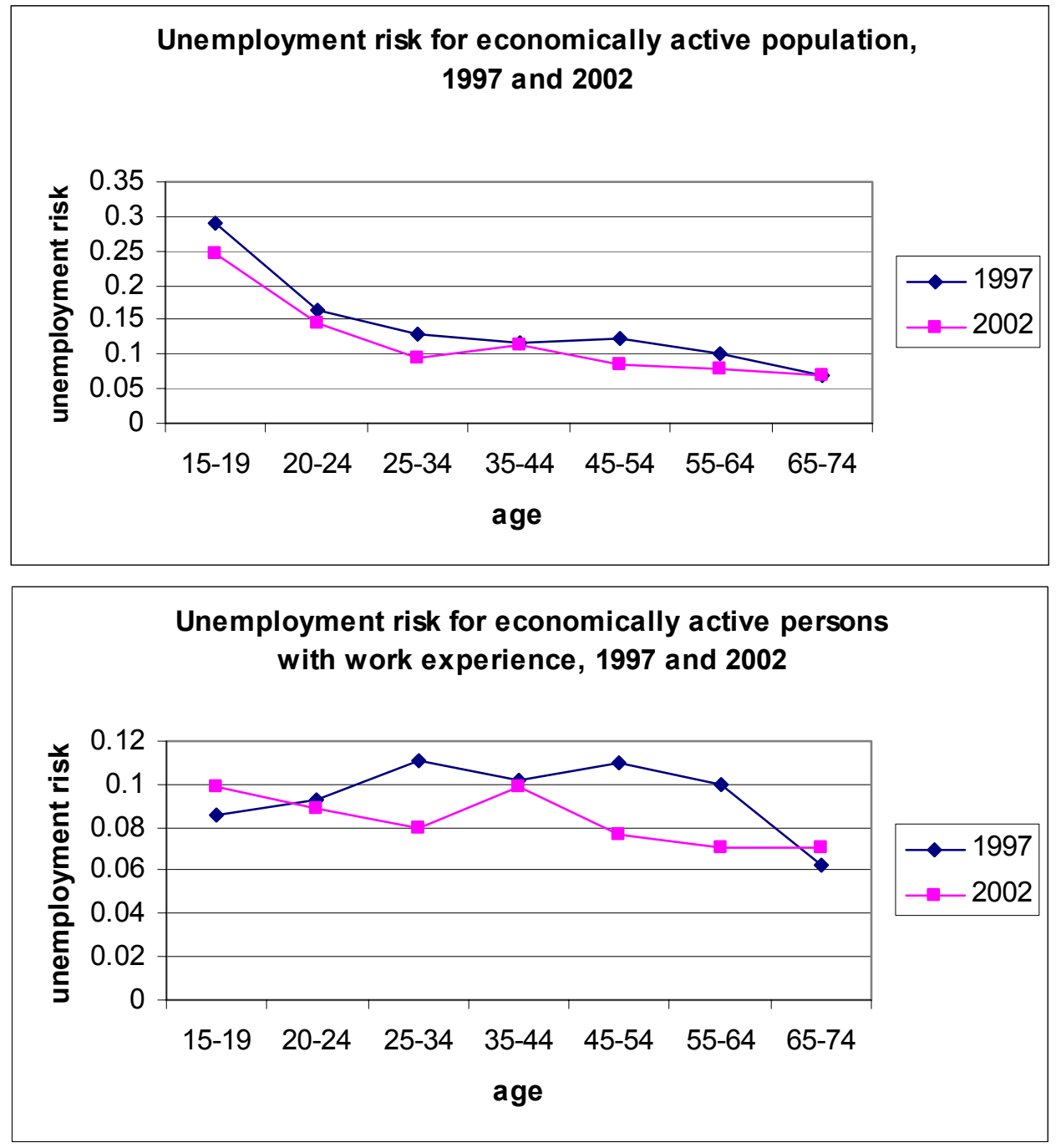

Notes: Upper panel is derived from logit models, controlling for education, gender, ethnicity and region. Lower panel is derived from models which control also for sector of economic activity and ownership (last job is used for unemployed).

Source: Calculation based on LFS data.

Regional disparities have increased. Table 11 summarizes information on regional effects from Appendix Tables 32-34. It shows clearly that the gap in labor market conditions between Riga region (excluding Jurmala) and the rest of the country, as well as the gap between Latgale, on one hand, and Riga, Vidzeme, and Zemgale, on the other, have increased during last 5 years (a finding which was not evident when registered unemployment rates and officially reported wages were considered in Section B). Unfavorable developments have been especially significant in terms of activity of both genders in Kurzeme and men's activity in Latgale. Disparities in unemployment and earnings have increased because in Riga and Riga district unemployment rates were falling and wages growing much faster than elsewhere. As far as the main cities are concerned, earnings rankings of Ventspils and Daugavpils have gone down substantially. 
Table 11. Ceteris Paribus Regional Differentials (vs. Riga and Riga district ${ }^{\text {a) }}$ ) in Activity, Unemployment Risk and Earnings, 1997 and 2002

\begin{tabular}{|c|c|c|c|c|c|c|c|c|c|c|}
\hline & \multicolumn{4}{|c|}{ Activity } & \multicolumn{4}{|c|}{ Unemployment risk } & \multicolumn{2}{|c|}{ Earnings } \\
\hline & \multicolumn{8}{|c|}{ percentage points } & \multirow{2}{*}{\multicolumn{2}{|c|}{$\begin{array}{c}\text { percent } \\
\text { both genders }\end{array}$}} \\
\hline & \multicolumn{2}{|c|}{ men } & \multicolumn{2}{|c|}{ women } & \multicolumn{2}{|c|}{ men } & \multicolumn{2}{|c|}{ women } & & \\
\hline & 1997 & 2002 & 1997 & 2002 & 1997 & 2002 & 1997 & 2002 & 1997 & 2002 \\
\hline Vidzeme & -1 & -2 & 2 & 1 & -1 & 2 & -2 & $3 * *$ & $-17 * * *$ & $-24 * * *$ \\
\hline Zemgale & -3 & -1 & -1 & -1 & 0 & $3 *$ & -1 & 1 & $-16^{* * *}$ & $-20 * * *$ \\
\hline Kurzeme & 0 & $-5 * * *$ & -2 & $-4 * * *$ & $-6 * * *$ & $4 *$ & $-5 * *$ & $3 *$ & $-11 * * *$ & $-21 * * *$ \\
\hline Latgale & $-8 * * *$ & $-11 * * *$ & $-3 * * *$ & $-3 * * *$ & 2 & $7 * * *$ & -2 & $4 * * *$ & $-22 * * *$ & $-34 * * *$ \\
\hline
\end{tabular}

Notes: ${ }^{\text {a }}$ Riga region includes also Jurmala city, but it is not included in the reference group for this table because it differs strongly from Riga and Riga district in terms of unemployment. Regional effects significant at $10 \%, 5 \%, 1 \%$ level are denoted by $*, * *, * * *$ respectively. Sources: Appendix Tables 32-34.

Additional evidence for increasing regional disparities is given by changes in elasticity of the wage curve (responsiveness of wages in main cities and districts to local registered unemployment rates). This indicator has changed from -0.07 in 1997 to -0.23 in 2002 for men, from -0.08 to -0.12 for women, and from -0.07 to -0.18 for both genders.

\section{CONCLUSION}

Stronger growth and progress in structural reforms in recent years have created a better environment for job creation in Latvia. The unemployment rate has declined from a peak of about 20 percent in the mid-1990s to 12 percent in 2002 and less than 11 percent in 2003. This trend was driven by employment growth, rather than the declines in labor force participation that characterized the initial phases of the transition to a market economy. Notwithstanding these advances, Latvia's labor market still suffers from serious problems that require further political initiatives in the years to come.

Unemployment rate remains above the average EU-15 level and ranks high among the new member states. Unemployment has a clear structural component: about 45 percent of unemployed had been without a job for more than 1 year in 2002 and 2003. While this proportion, lower than in Poland, Lithuania, Slovakia, or Italy, is similar to the average EU-15 figure, it represents a serious economic and social challenge when combined with high unemployment rate. Moreover, a significant and growing share of the long-term unemployed end up leaving the labor market instead of being reintegrated into employment, especially in rural areas. Male participation rate is now below the corresponding EU-15 average, signaling discouragement among some (older and unskilled) men laid off in the restructuring process.

There is also a clear geographical dimension to unemployment and underemployment. Higher unemployment in certain backward areas is mainly due to lower job creation and a mismatch of skills of the long-term unemployed rather than higher rates of job destruction. Lack of labor demand in backward areas as a key driver of regional disparities is also confirmed by the negative association between average wages and unemployment rates across regions.

Returns to education have increased rapidly during the transition but there is also evidence of a growing mismatch between labor demand and skills provided by formal education (e.g., technical secondary education). Workers with high levels of education have higher chances to maintain their jobs and to find new ones if unemployed, and this human capital effect is even stronger among the new entrants in the 
labor market for whom competition for jobs in the formal sector is very high. "New" education has higher market value, especially in the case of universities and general secondary schools.

The significant structural changes in the composition of the economy across and within sectors have also drastically changed the age profile of wages. Compared with the centrally planned period, returns to experience have declined and may be nonexistent for many adult workers without higher education. For these workers, maintaining a job or finding a new one in case of a layoff has become a major challenge.

The relative position of youths and women in the labor market, compared with prime-age men, is less unfavorable than in many other countries. But well-educated women tend to receive lower wages than men with similar characteristics, and gender wage gap has increased recently.

Unemployed representatives of ethnic minorities have lower chances to find a job within a year, other things equal, while the difference between genders is not significant. Neither ethnicity nor gender matter as long as transition from employment to unemployment is concerned.

Analysis of job search methods by the unemployed indicates that two target groups of state employment policy - the young unemployed and the long-term unemployed, appear to make relatively little use of the public employment service.

For Latvia, promoting human capital is a vital component of a successful long-term policy aimed at the 2010 Lisbon Strategy Targets for employment, competitiveness, and social inclusion, although major efforts are still required to improve the match between skills offered by the education system and those required in the market. Complementary policies should encourage labor force participation; improve skills for low wage unskilled workers; reduce the tax wedge on low-skill wages; and promote commuting as one of the most efficient (in the short and medium term) tools to reduce disparities and mismatch.

Substantial changes in labor market policies and institutions have been introduced in Latvia in recent years. Although these reforms have yielded good macroeconomic results and played an important role in stimulating job creation in services and export sectors, they have had limited success thus far in fighting unemployment. Using data from labor force surveys, this study has attempted a more precise understanding of the country's labor force and its dynamics. These analyses should provide useful insights to policymakers for improving the functioning of Latvia's labor market. This is particularly important given Latvia's medium-term plans to adopt the Euro and to join the EU Pact on Stability and Growth, which will eventually leave labor market as the only effective economic tool to adjust to shocks.

\section{REFERENCES}

Barrett, Alan, John FitzGerald and Brian Nolan (2000), Earnings Inequality, Returns to Education and Immigration into Ireland, IZA Discussion Paper No. 167.

Blanchflower, David G. and Andrew J. Oswald (1994). The wage curve. MIT press.

Brainerd, E. (2000), Women in Transition: Changes in Gender Wage Differentials in Eastern Europe and the Former Soviet Union, Industrial and Labour Relations Review, Vol.54, No.1, pp.138-162.

Brücker, Herbert and Parvati Trübswetter (2003), “Are East-West Migrants in Germany

Favourably Self-Selected?” Mimeo, Berlin: German Institute for Economic Research (DIW Berlin).

Central Staistical Bureau of Latvia (2003a), Latvia's Regions in Figures. Riga. 
Central Staistical Bureau of Latvia (2003b), Labour Force Surveys: main indicators in 1996-2001.

Central Staistical Bureau of Latvia (2004), Labour Force Surveys: main indicators in 2003.

Ehrenberg, Ronald G. and Robert S. Smith (2003). Modern Labor Economics, Theory and Public Policy. 8th ed., Addison Wesley.

Hazans, Mihails (2002), "Age-Earnings Profiles and Human Capital in Transition: Evidence from the Baltic States”. http://www.eurofaculty.lv/papers/DownloadsEconomics/mihails_hazans.pdf

Hazans, Mihails, John Earle, and Raul Eamets (2002), "Labour Markets in the Baltic States", Background paper for the OECD (2003) publication "Labour Market and Social Policies in the Baltic Countries".

Hazans, Mihails (2003a), "Commuting in the Baltic States: Patterns, Determinants, and Gains" ZEI (Center for European Integration Studies, Univ. of Bonn) Working Paper No. B02-2003

(available at www.zei.de)

Hazans, Mihails (2003b), "Determinants of inter-regional migration in the Baltic Countries," ZEI (Center for European Integration Studies, Univ. of Bonn) Working Paper No. B17-2003.

(available at www.zei.de)

Hazans, Mihails (2003c), "Potential emigration of Latvian labour force after joining the EU and its impact on Latvian labour market", http://www.gdnet.org/cf/search/display.cfm? search $=$ ALLKB\&act $=$ DOC\&docnum $=$ DOC14353

Hazans, Mihails (2003d), "Returns to Education in the Baltic Countries," paper presented to the conference „Human Development in EU Accession Countries, Riga, 1-2 June 2003.”

(http://www.biceps.org/documents/Hazans RETURNSTOEDUCATION.pdf).

Hazans, Mihails (2004a), "Does Commuting Reduce Wage Disparities?", Growth and Change, Volume 35 Number 3, Special Issue on Commuting, pp. 360-390.

Hazans, Mihails (2004b) "Looking for the Workforce: The Elderly, Discouraged Workers, Minorities and Students in the Labour Market", In: AccessLab, Report on Workpackage 4, Human Capital, Spatial Mobility, and Lock-In - The Experience of Candidate countries. http://accesslab.wifo.ac.at/

Hellerstein, Judith K., David Neumark, and Kenneth R. Troske (1999), "Wages, Productivity, and Worker Characteristics: Evidence from Plant-Level Production Functions and Wage Equations," Journal of Labor Economics, Vol. 17(3), July, 409-46.

Jurajda, Štepán (2000), “Gender Wage Gap and Segregation in Late Transition”, Davidson Institute Working Paper No. 306.

Kunze, Astrid (2000), "The Determination of Wages and the Gender Wage Gap: A Survey", IZA Discussion Paper No. 193.

Laxton, Valerie (2001) "Occupational Segregation and gender wage gap in Eastern Europe". Paper presented to workshop "Labour Markets, Work and Welfare during the Transition and Integration Processes, Riga, 23-30 March 2001”. 
Newell, Andrew (2001), "The Distribution of Wages in Transition Countries", IZA Discussion Paper No. 267.

Newell, Andrew and Barry Reilly (2001), The Gender Pay Gap in the Transition from Communism: Some Empirical Evidence, IZA Discussion Paper No. 268

Oaxaca, Ronald M. (1973), Male - Female Wage Differentials in Urban Labor Markets", International Economic Review, 14, pp. 693-709.

Oaxaca, Ronald M, and Michael R. Ransom (1994), "On Discrimination and the Decomposition of Wage Differentials", Journal of Econometrics, 61 (1), pp. 5-21.

OECD (2003a), Labour Market and Social Policies in the Baltic Countries. Paris

OECD (2003b) Determinants of Earnings in Estonia, Latvia and Lithuania

(http://www.oecd.org/dataoecd/18/10/2493411.pdf)

OECD (2003c) Unemployment Risk Factors in Estonia, Latvia and Lithuania (http://www.oecd.org/dataoecd/28/55/2493996.pdf)

Pailhé, Ariane (2000), Gender Discrimination in Central Europe during the Systematic Transition, Economics of Transition, Vol.8, No.2, pp. 505-535.

Rauhmane, Sabina, Ilze Palma and Ieva Sloka (2001), Intra-Industrial and Intra-Regional Wage Differentials in Latvia, http://www.eurofaculty.lv/papers/DownloadsEconomics/sabina_rauhmane.pdf

Rutkowski, Jan (2003), "Rapid Labor Reallocation with a Stagnant Unemployment Pool: The Puzzle of the Labor Market in Lithuania." World Bank Policy Research Working Paper No. 2946. Washington, D.C.

Stake, Dagnija, Minister of Welfare, and Anna Diamantopoulou, European Commissioner (February 6, 2003). Joint Assessment of Employment Policy Priorities in Latvia.

Trapeznikova, Ija, Olga Rastrigina, and Jelena Popova (2003), Part-time Employment and Underemployment in the Latvian Labour Market, Baltic Journal of Economics, Vol. 3, No 2, pp. 4258

World Bank, 2004. "Latvia: The Quest for Jobs and Growth". A World Bank Country Economic Memorandum.

Zvidriňš, P. (ed.) (1999), Prognosis of demographic development in Latvia: 1998-2025. Informative material, Riga: University of Latvia, 1999. 


\section{APPENDIX}

Appendix Figure 1. Old Age Dependency Ratio Projections, Latvia

\section{Dependency ratio}

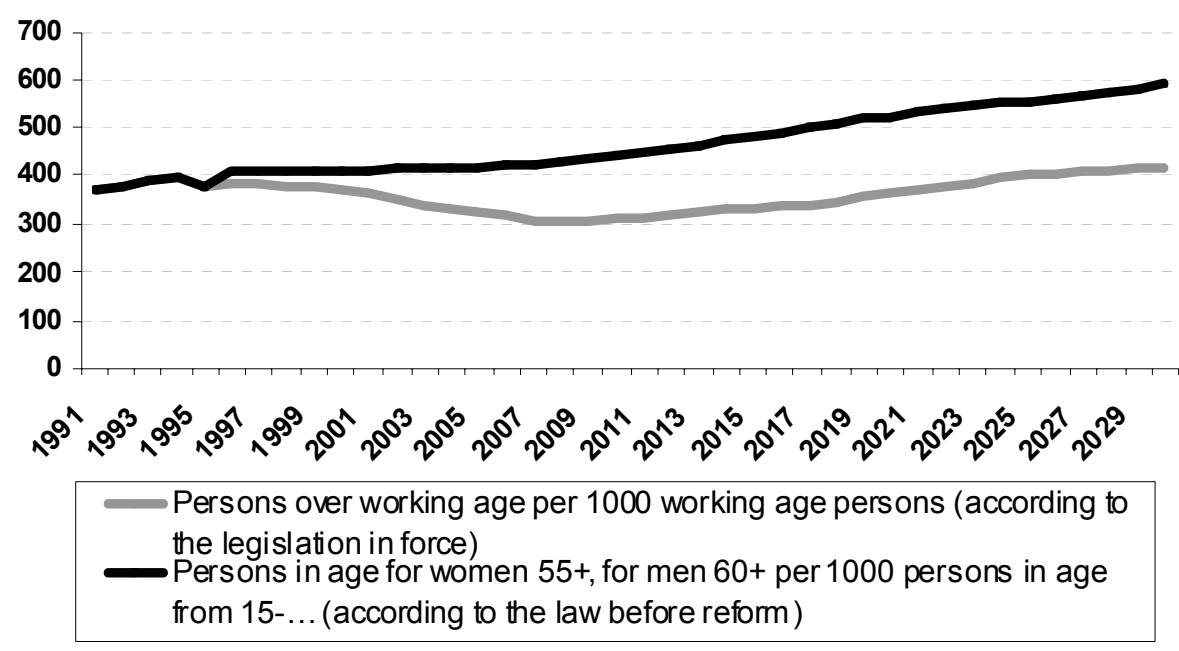

Source: Zvidriņš (1999).

Appendix Figure 2. UN - ILO Projection of Inverse Old Age Dependency Ratio (population aged 20-64 to population aged 65 and older):

Latvia, Lithuania and Western Europe, 1990-2040

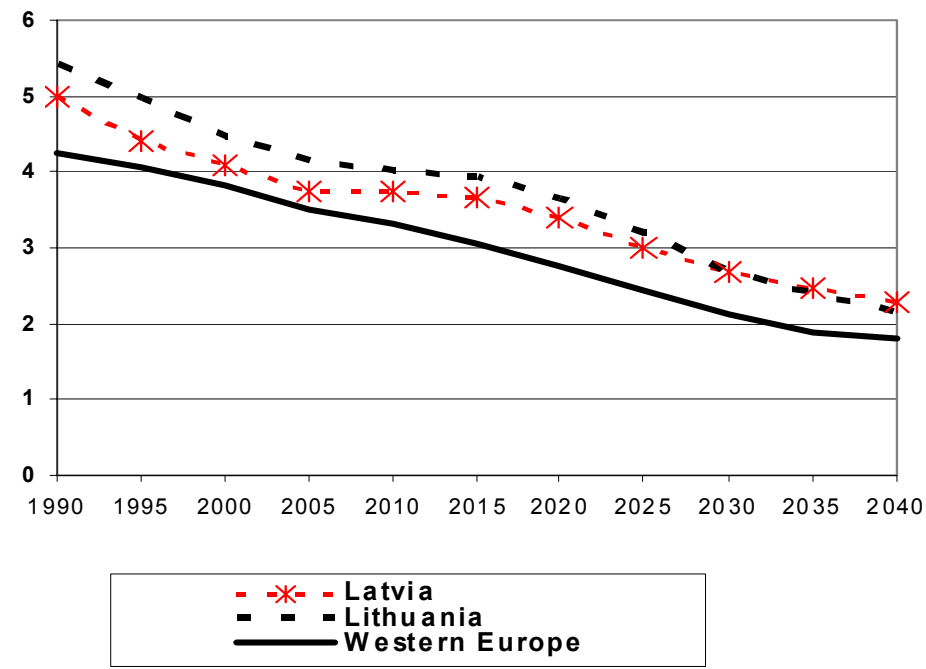

Source: adapted from OECD (2003a). 
Appendix Figure 3. Activity, Employment and Unemployment Rates by Gender and Age, 19972002

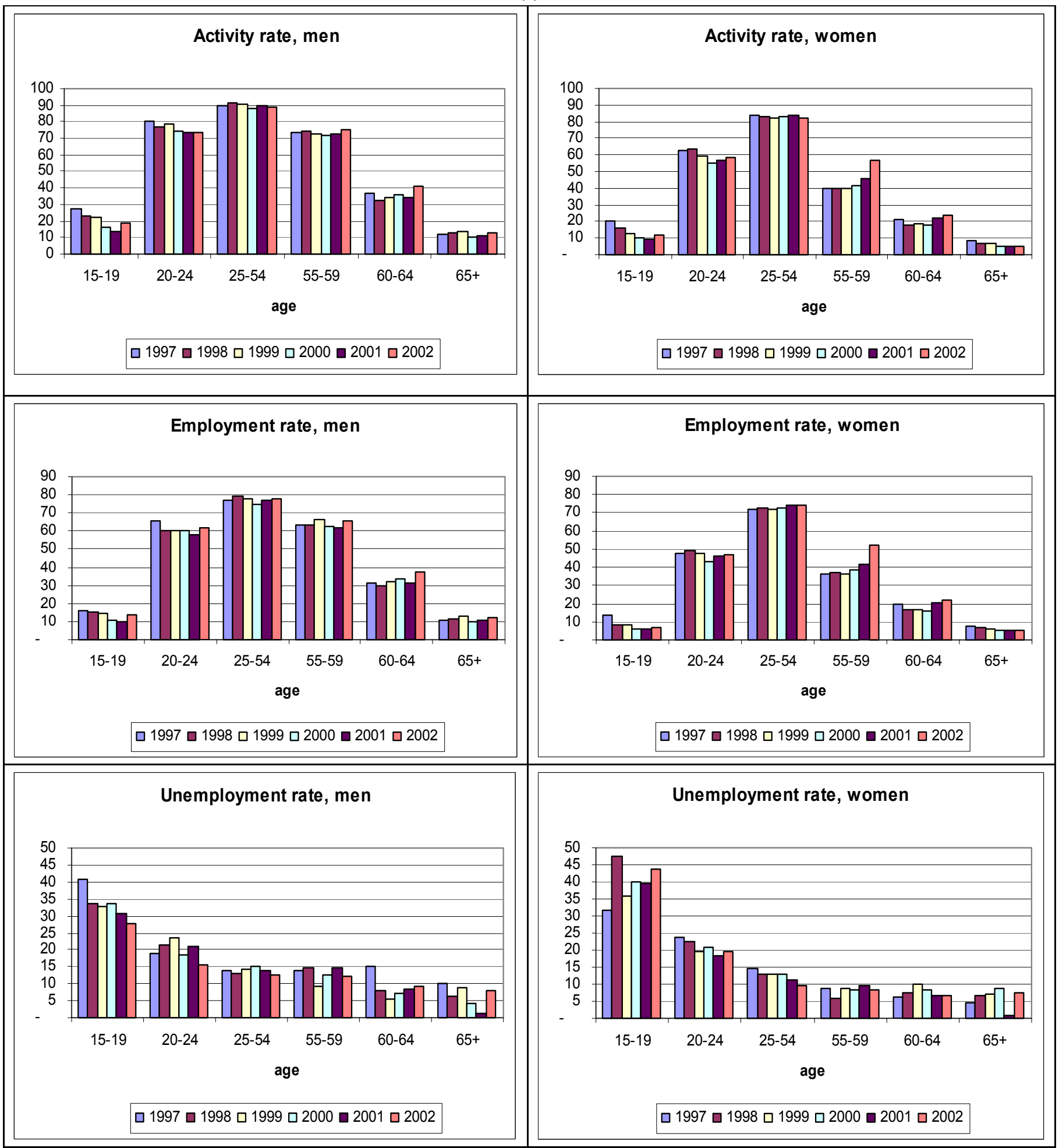

Source: Calculations based on LFS data (see Appendix Table 1). 
Appendix Figure 4. Self-Employment, Part-Time Employment, Underemployment, and Secondary Employment as a Percentage of Total Employment, 1997-2002

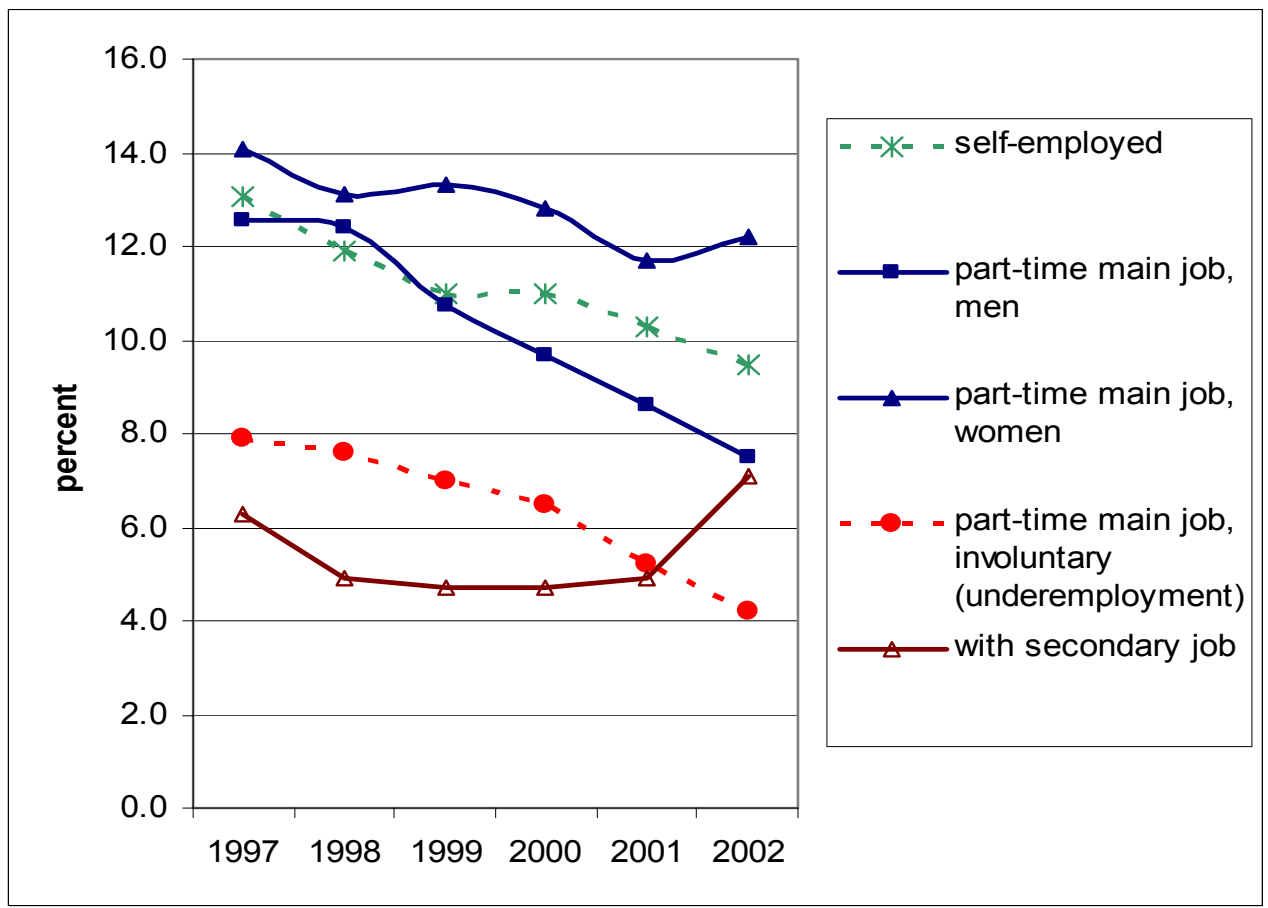

Source: Central Statistical Bureau of Latvia.

Appendix Figure 5. Ratio of Unemployment Rates by Education Level:

Upper Secondary vs Higher. CEC-10, 1999-2000; Latvia, 1999-2002

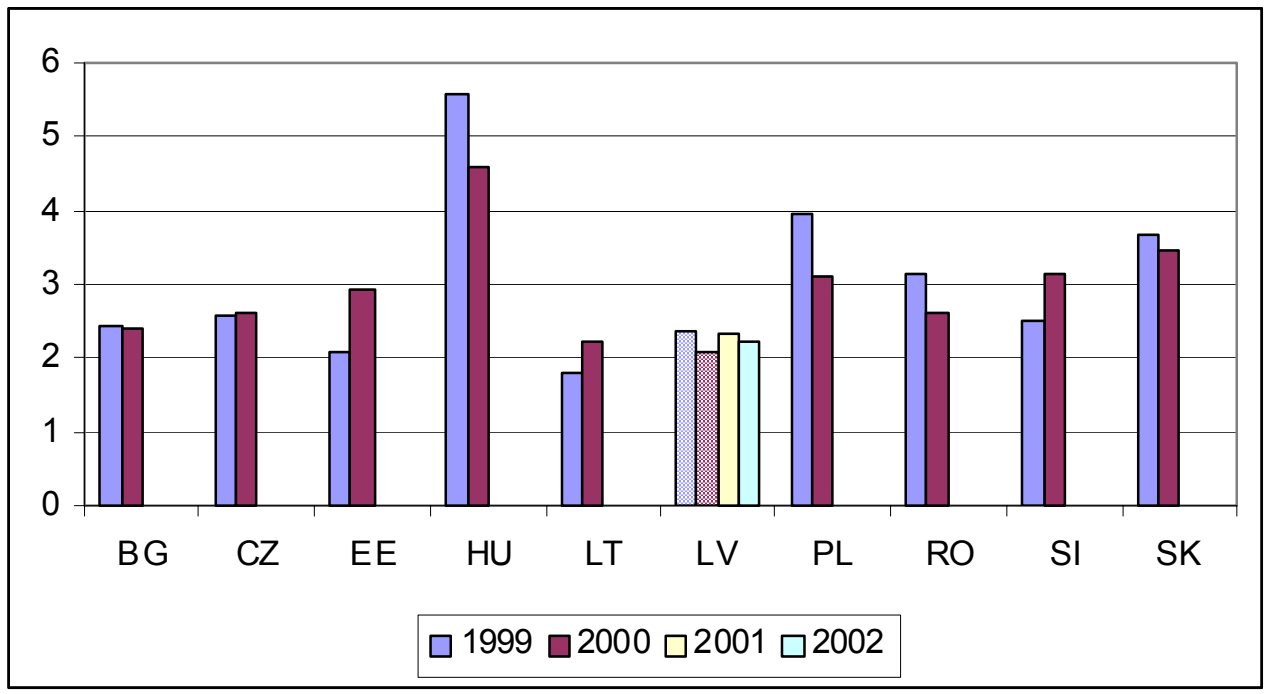

Source: "Employment and Labour .Market in Central European countries", 2001/3, and Calculation. 
Appendix Figure 6. Incidence of Long-Term (1 year and more) Unemployment in Central and Eastern European Countries (per cent of all unemployed persons), 2000 and 2002

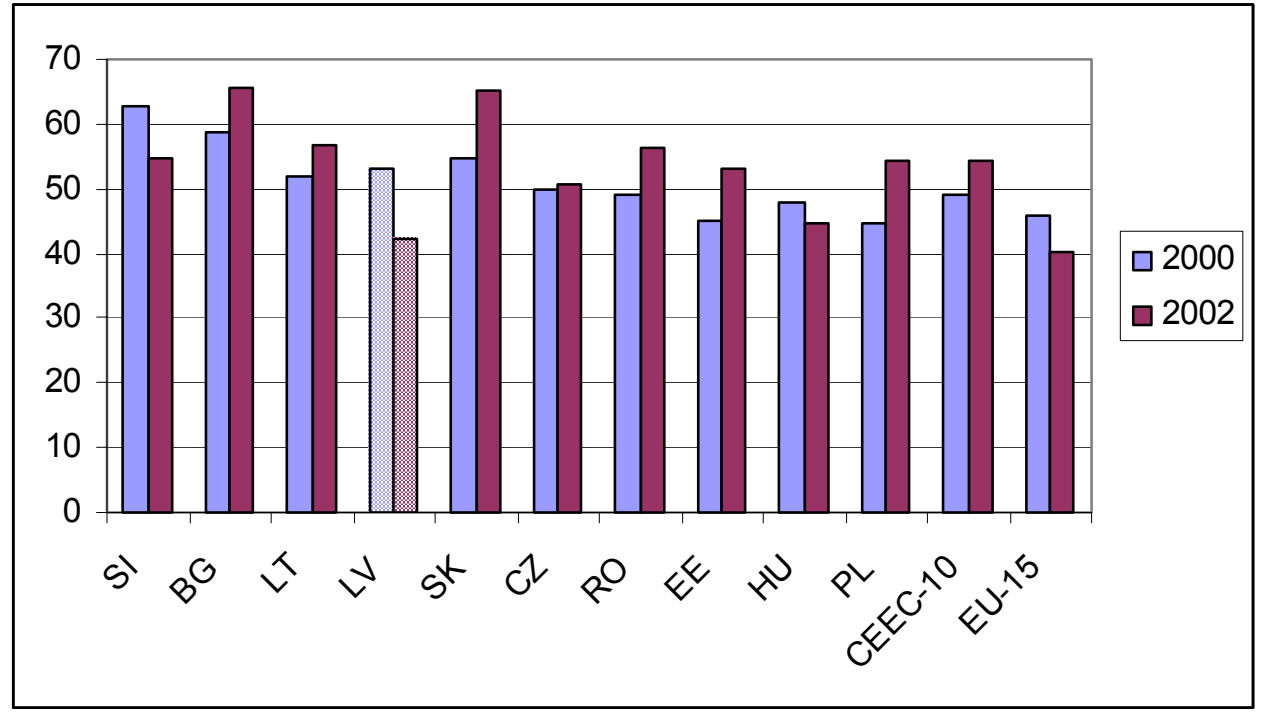

Source: Eurostat (Spring LFS data).

Appendix Figure 7. Average Gross Wages vs Registered Unemployment Rtes in Latvian Main Cities $^{\text {a }}$ and Districts, 2000

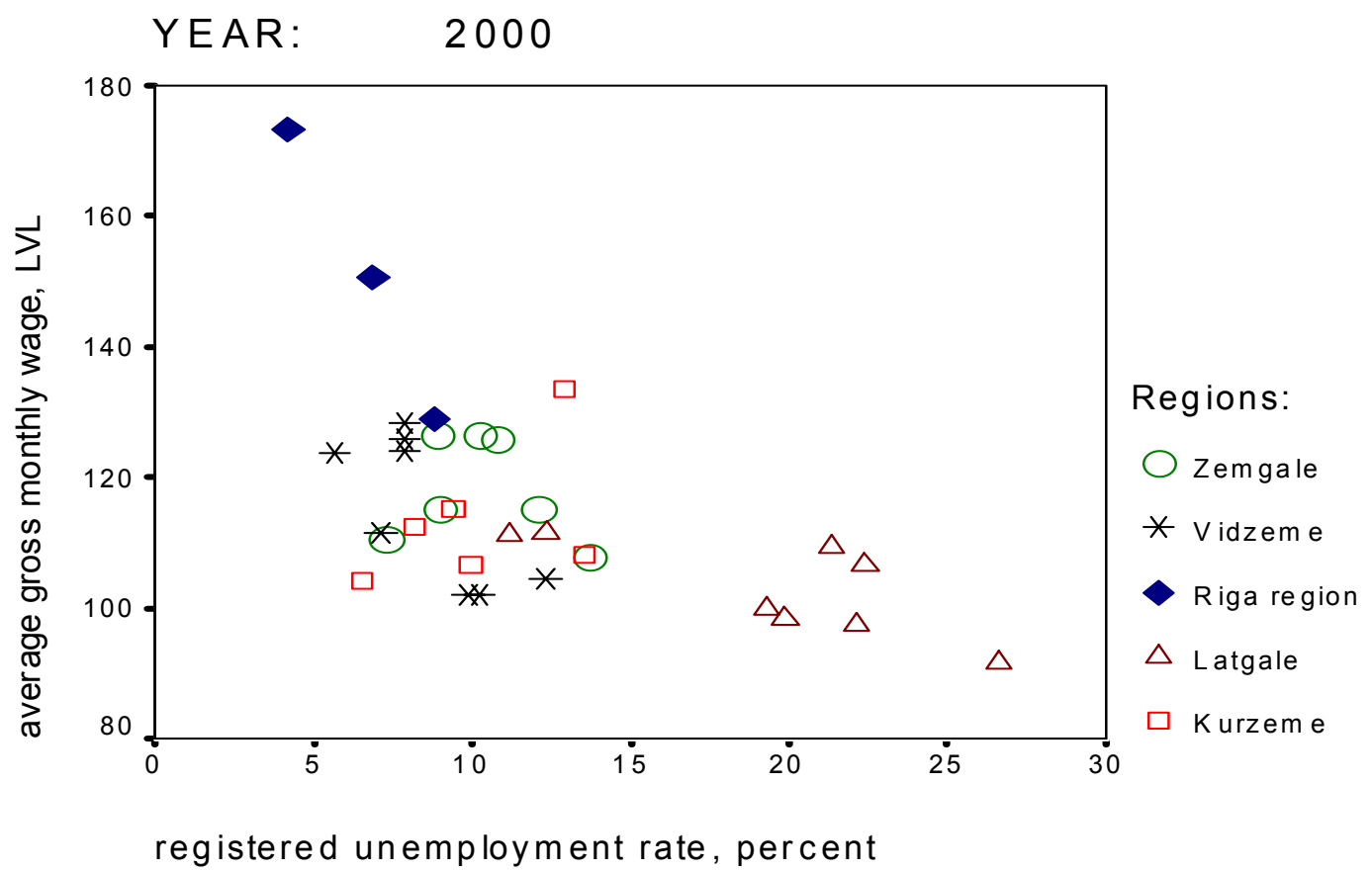

Notes: ${ }^{a}$ Ventspils (unemployment $7.1 \%$, wage 222 LVL) excluded. Source: Calculation based on official data. 
Appendix Figure 8. Registered Unemployment Rates and Gross Average Wages by Region, 19922002 (per cent of national average)
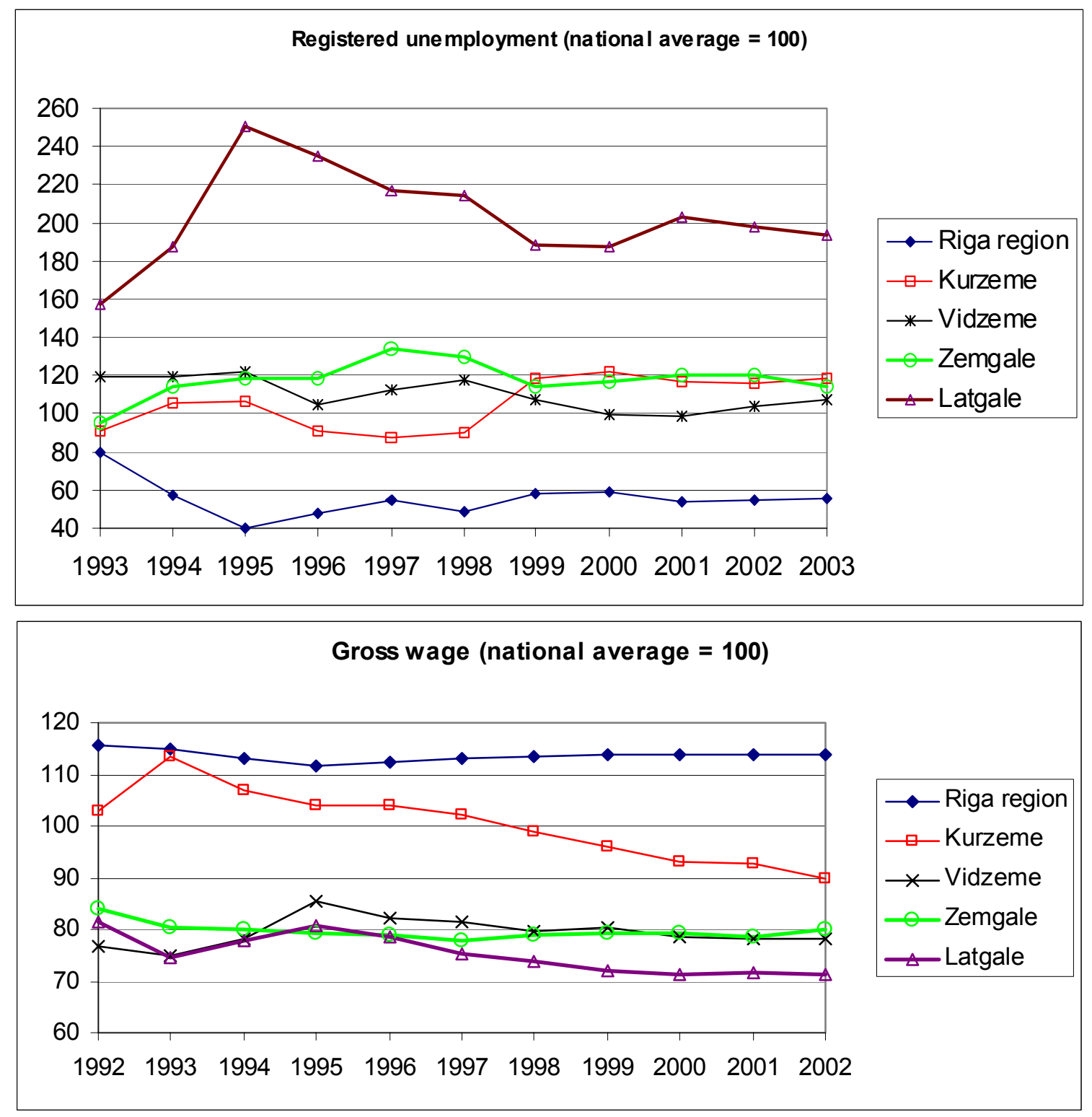

Notes: Registered unemployment rates at the beginning of the year; in 2003 calculation methodology of these rates was changed (persons above retirement age are excluded from labor force), but for comparability old methodology was used also for 2003 here.

Source: Calculations based on official data. 
Appendix Figure 9. Regional Disparities in Unemployment and Wages, 1992-2002

33 NUTS-IV regions, Weighted
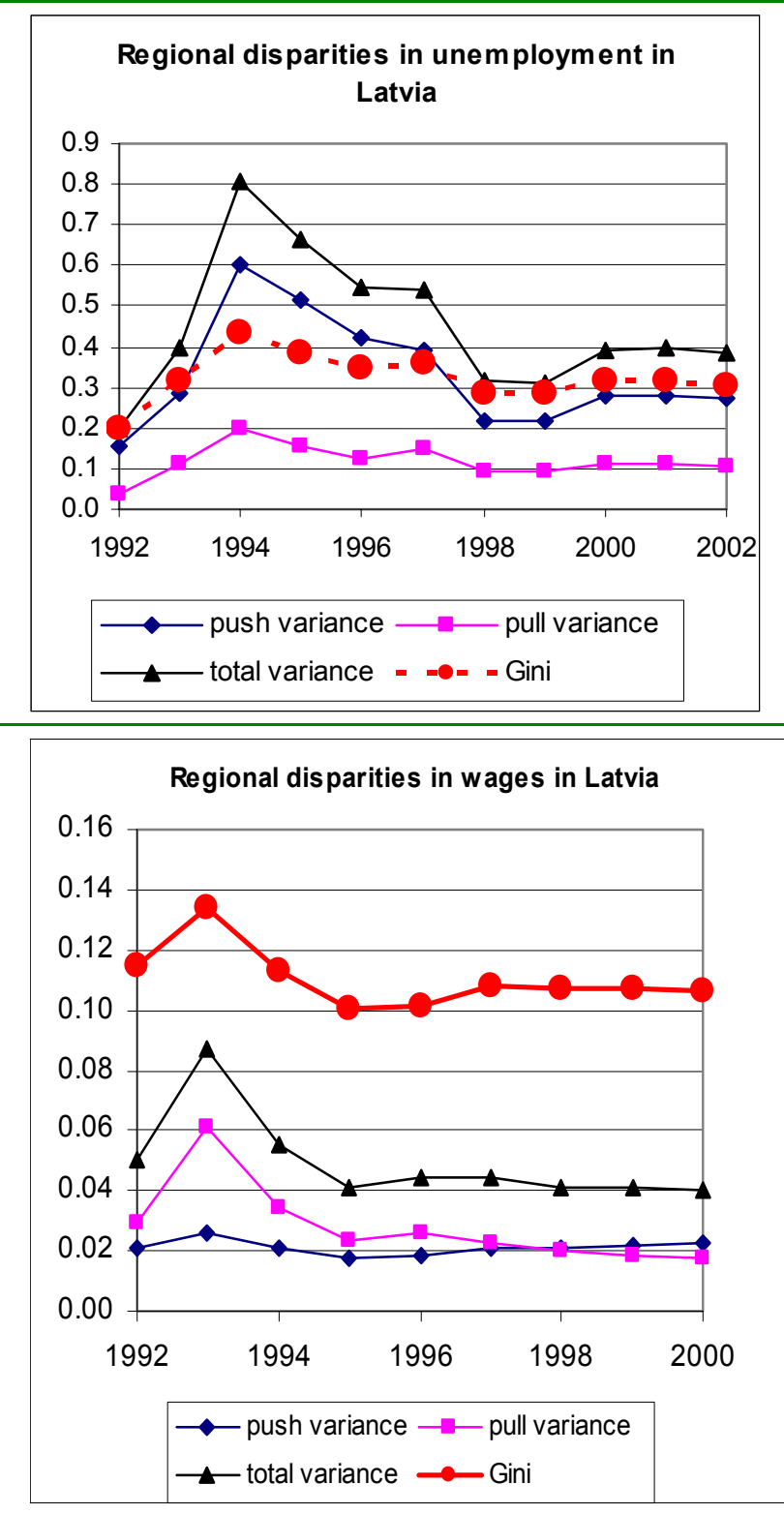

33 NUTS-IV regions, Non-weighted
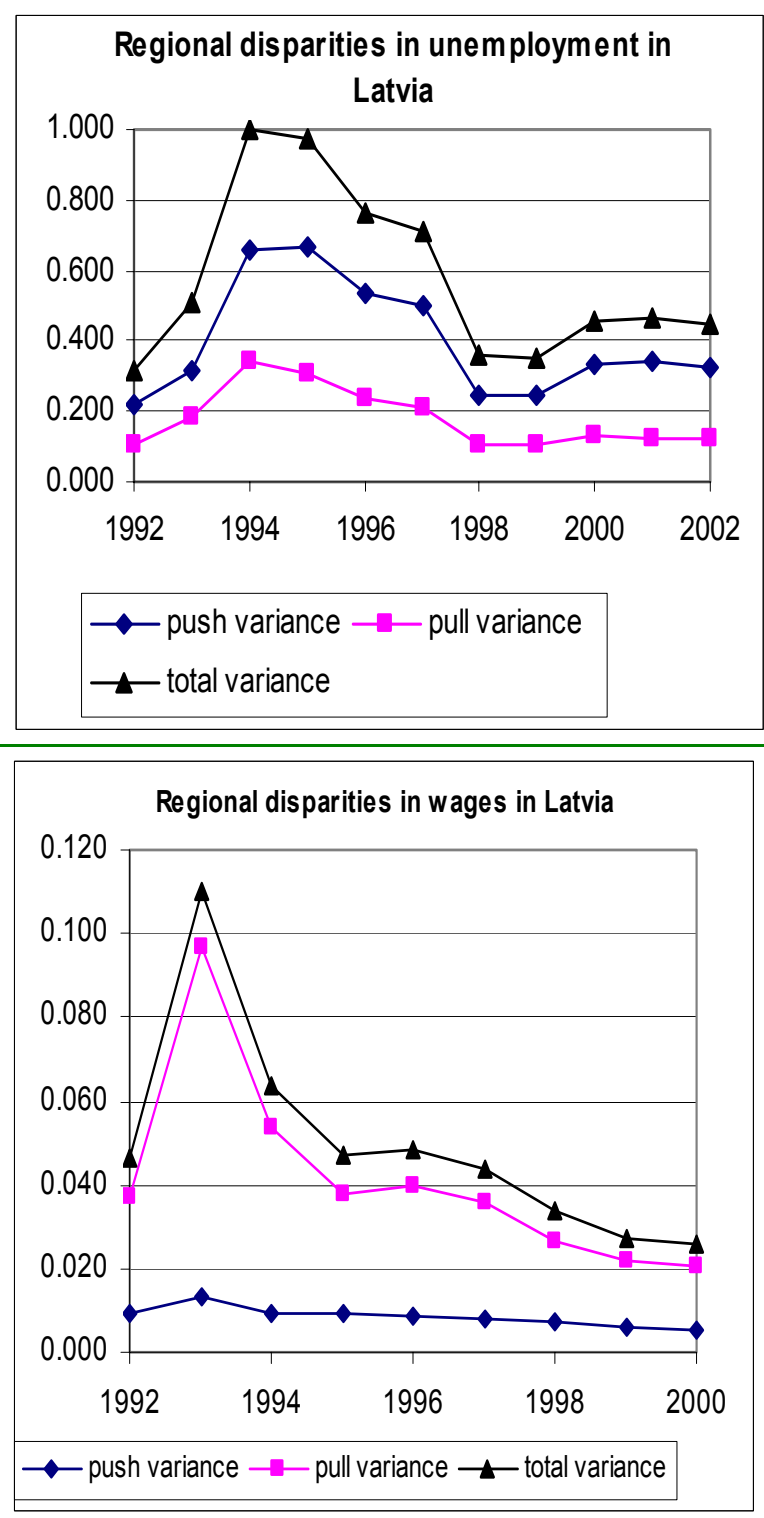

Notes: Variance in all cases is normalized by squared national average (i.e. total weighted variance is squared coefficient of variation). The Gini coefficient is calculated by the same formula for unemployment and wages and ignores inequality within regions of interest. In the case of wages it can also be interpreted as contribution of variation in regional average wages in total Gini for the labor income.

Source: Hazans (2003b). 
Appendix Figure 10. Outflows from Agriculture, Industry, and Services by Destination, $1997-2002$
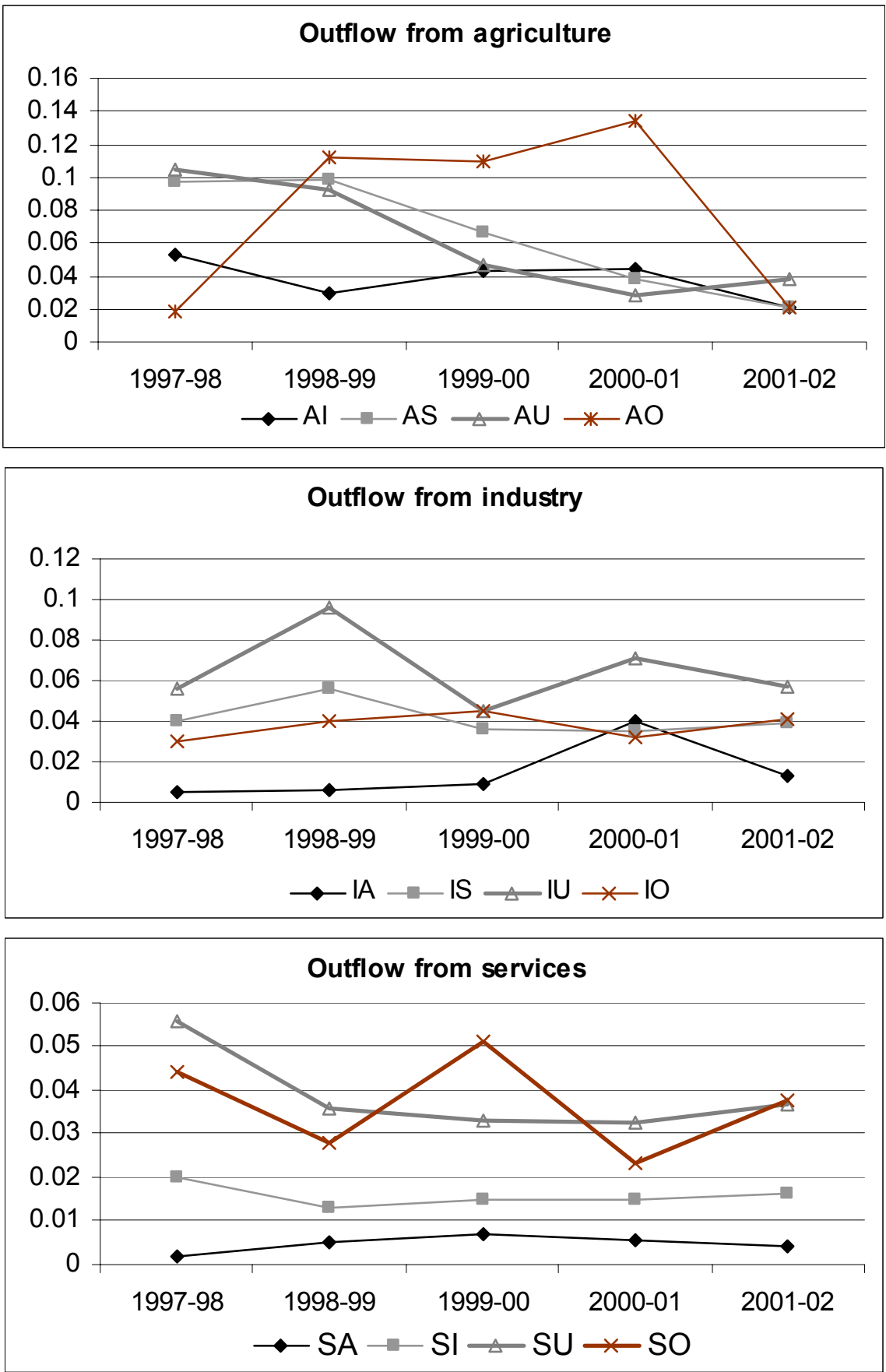

Source: Calculation based on LFS data (see Appendix Table 15). 
Appendix Figure 11. One-Year Probability of Finding a Job (upper panel) and Exit to Inactivity (lower panel) by Age Group and Region

(controlling for level and field of education, gender, and ethnicity
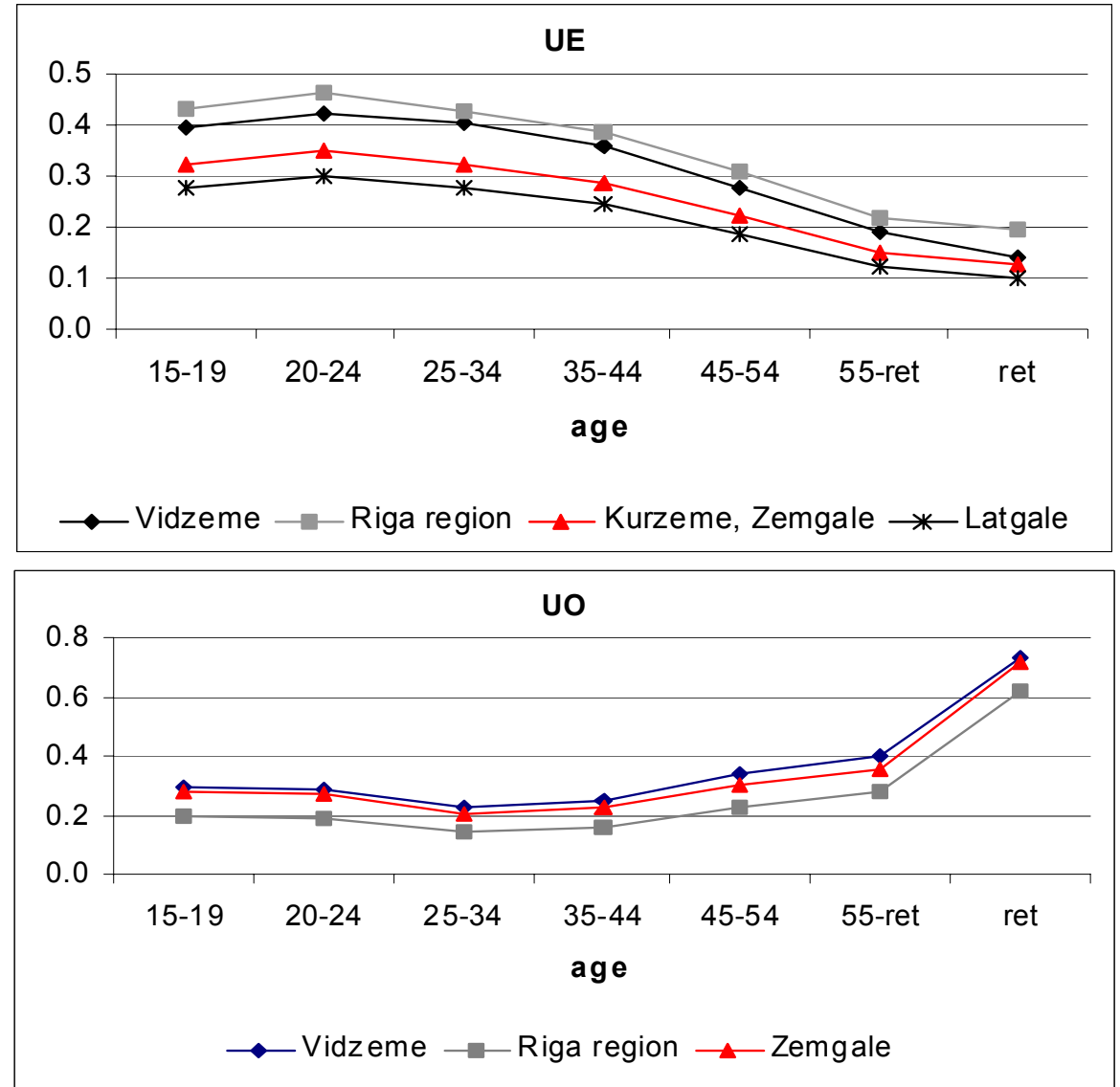

Note: Probabilities of leaving labor force for Kurzeme and Latgale (nor shown) are similar to Zemgale. "Ret" stands for retirement age. Source: Calculations based on LFS 2002.

\section{Appendix Figure 12. One-Year Probability of Finding a Job and Exit to Inactivity by Age Group and Urban or Rural Residence}

(controlling for level and field of education, gender, and ethnicity)

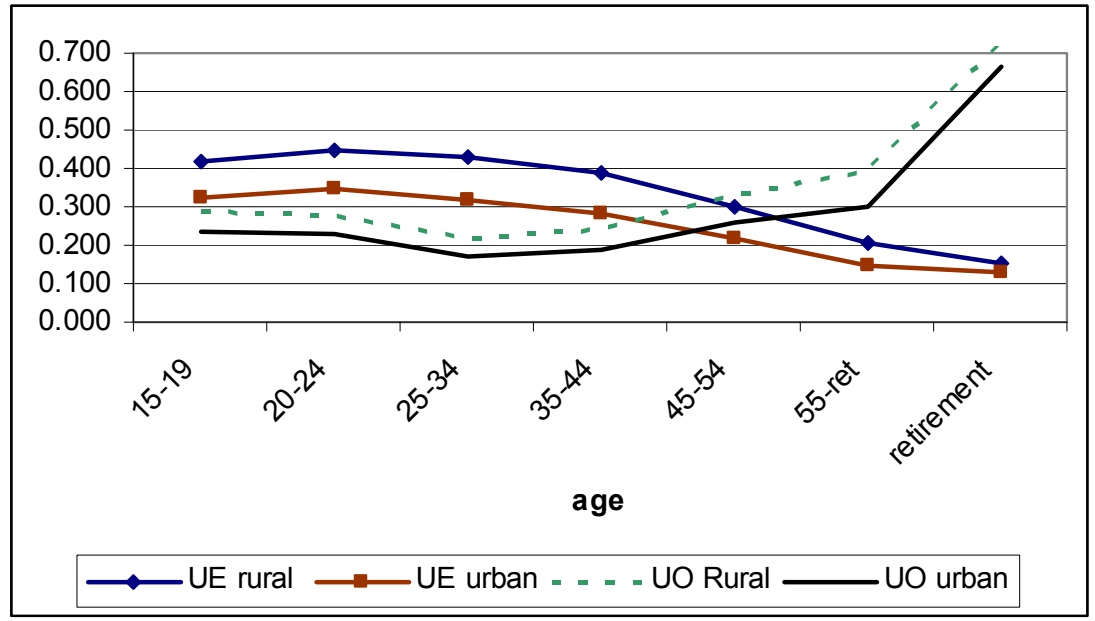

Notes: UE - probability to move from Unemployment to Employment;

$\mathrm{UO}$ - probability to move from unemployment to Out of the labor force. Source: Calculations based on LFS 2002. 


\section{Appendix Figure 13. Predicted Probability of Moving from Employment to Out of the Labor}

Force (EO) between 2001 and 2002, by Age, Gender, and Ethnicity
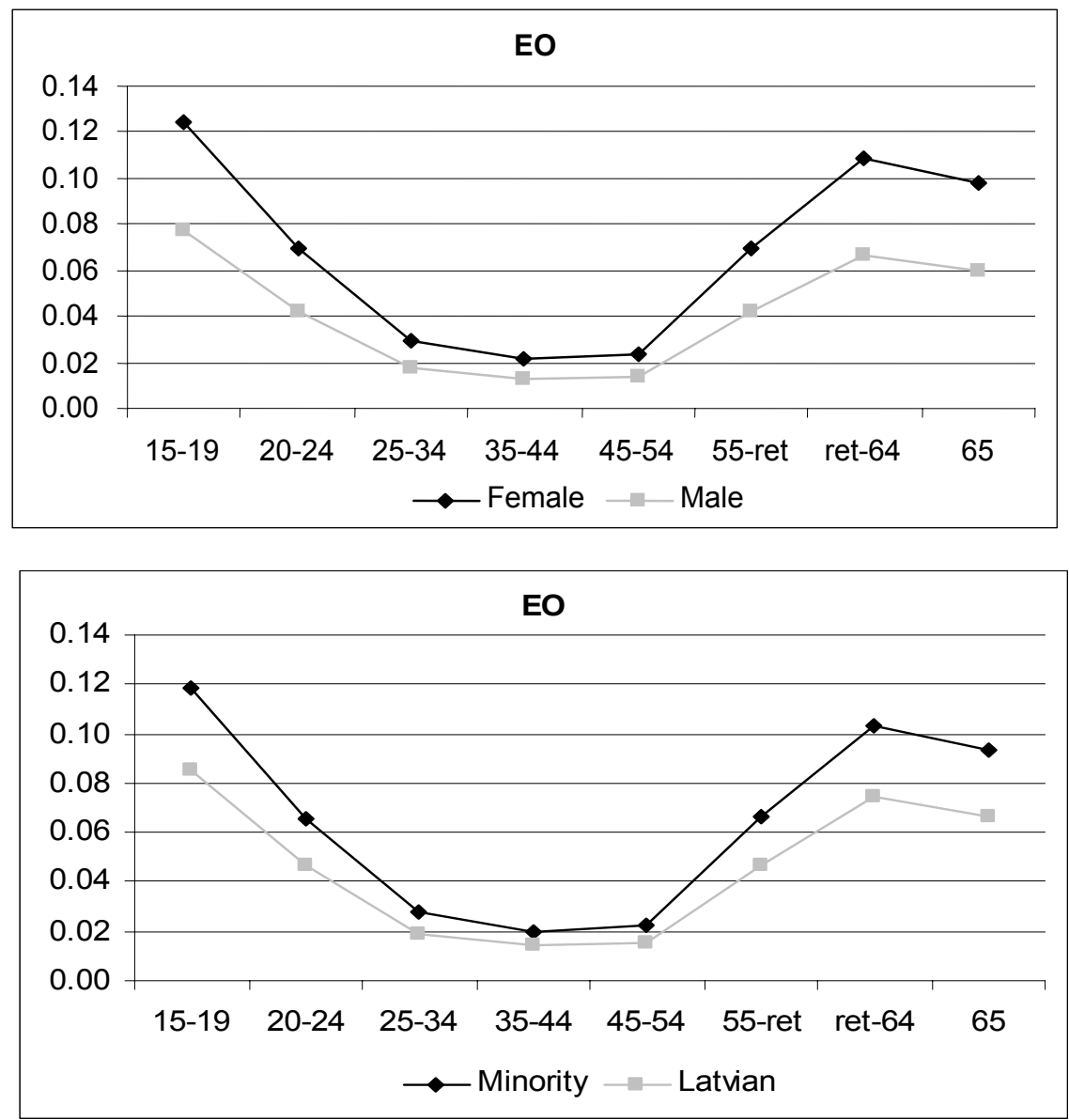

Notes: Education, employment status, occupation, economic activity and residence are controlled (see Appendix Table 19). "Ret" stands for retirement age. Source: Calculations based on LFS 2002.

Appendix Figure 14. Predicted Probability of Moving from Employment to Unemployment (EU) and from Employment to Out of the Labor Force (EO) between 2001 and 2002, by Age and Region of Residence.
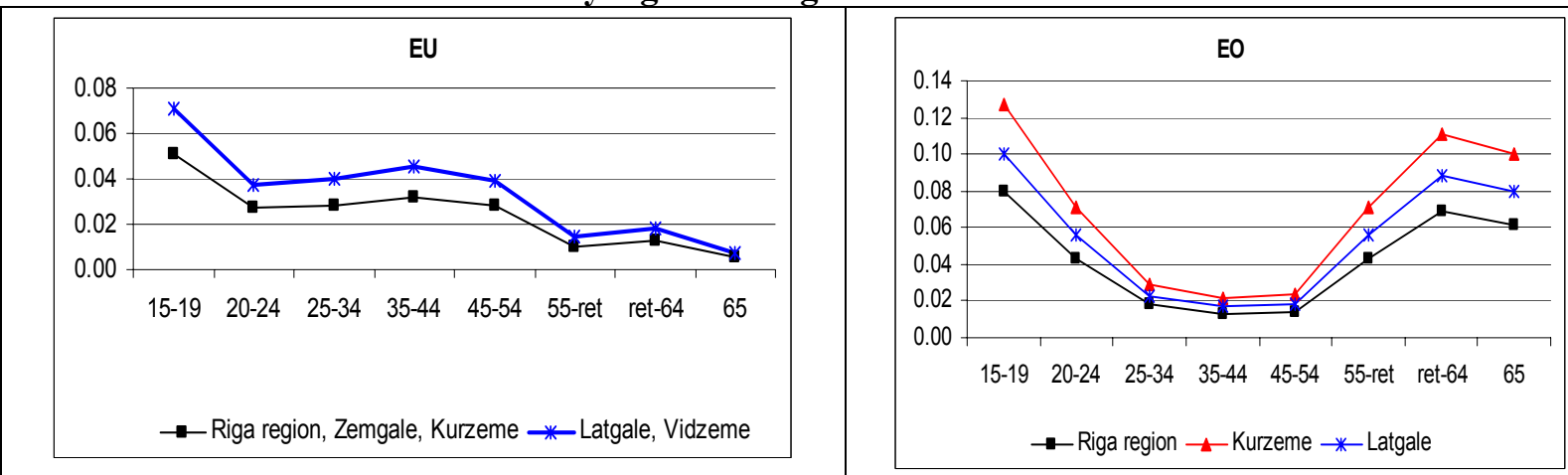

Notes: Education, gender, ethnicity, employment status, occupation, economic activity are controlled (see Appendix Table 19). Probabilities EU for Vidzeme are virtually identical with the ones for Latgale, while for Zemgale and Kurzeme they are not significantly different from Riga region. Probabilities EO for Vidzeme and Zemgale coincide with each other; for age between 25 and retirement they are practically equal to Kurzeme's probabilities, but for the youth and elderly are lower by roughly 0.01 . "Ret" stands for retirement age. Source: Calculations based on LFS 2002. 
Appendix Figure 15. Predicted Probability of Moving from Employment to Unemployment (E-U) between 2001 and 2002 by Urban or Rural Residence and Age.

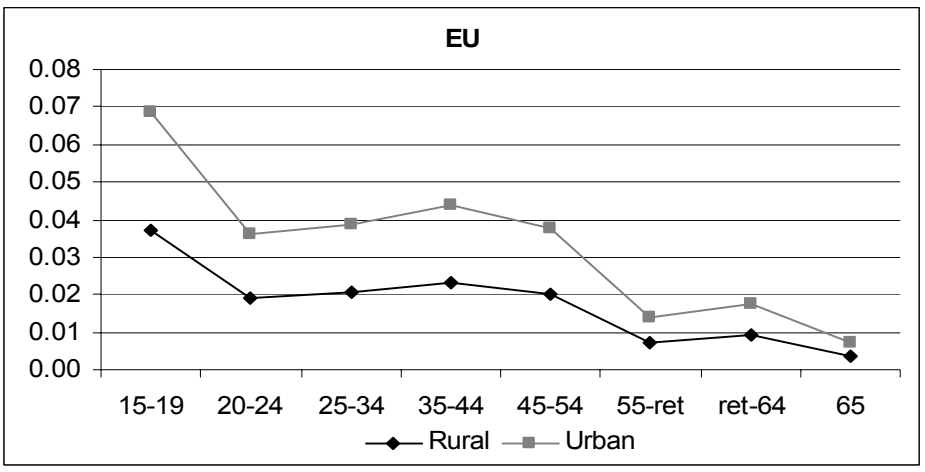

Notes: Education, gender, ethnicity, employment status, occupation, economic activity, and region of residence are controlled (see Appendix Table 19). "Ret" stands for retirement age.

Source: Calculations based on LFS 2002.

Appendix Figure 16. Predicted Probability of Moving from Employment to Unemployment (EU) and from Employment to Out of the Labor Force (EO) between 2001 and 2002, by Age and Occupation.

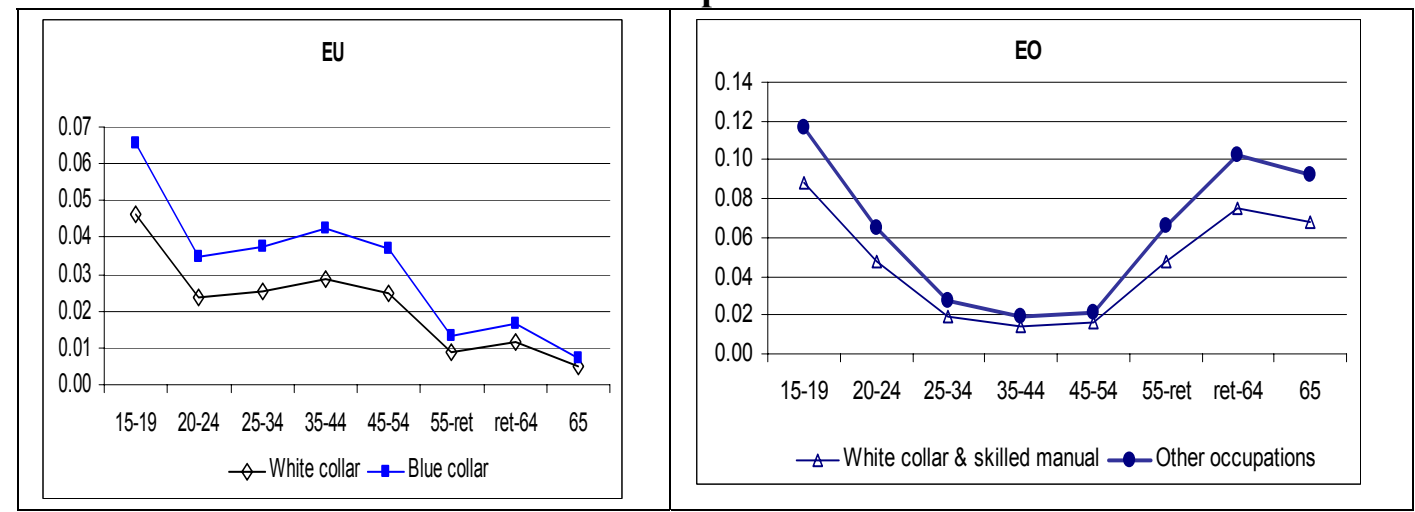

Notes: Education, gender, ethnicity, employment status, occupation, economic activity, and residence are controlled (see Appendix Table 19). "Ret" stands for retirement age.

Source: Calculations based on LFS 2002. 


\section{Appendix Figure 17. Predicted Probability of Moving from Employment to Unemployment (EU) and from Employment to Out of the Labor Force (EO) between 2001 and 2002 by Age and Sector of Employment in 2001.}

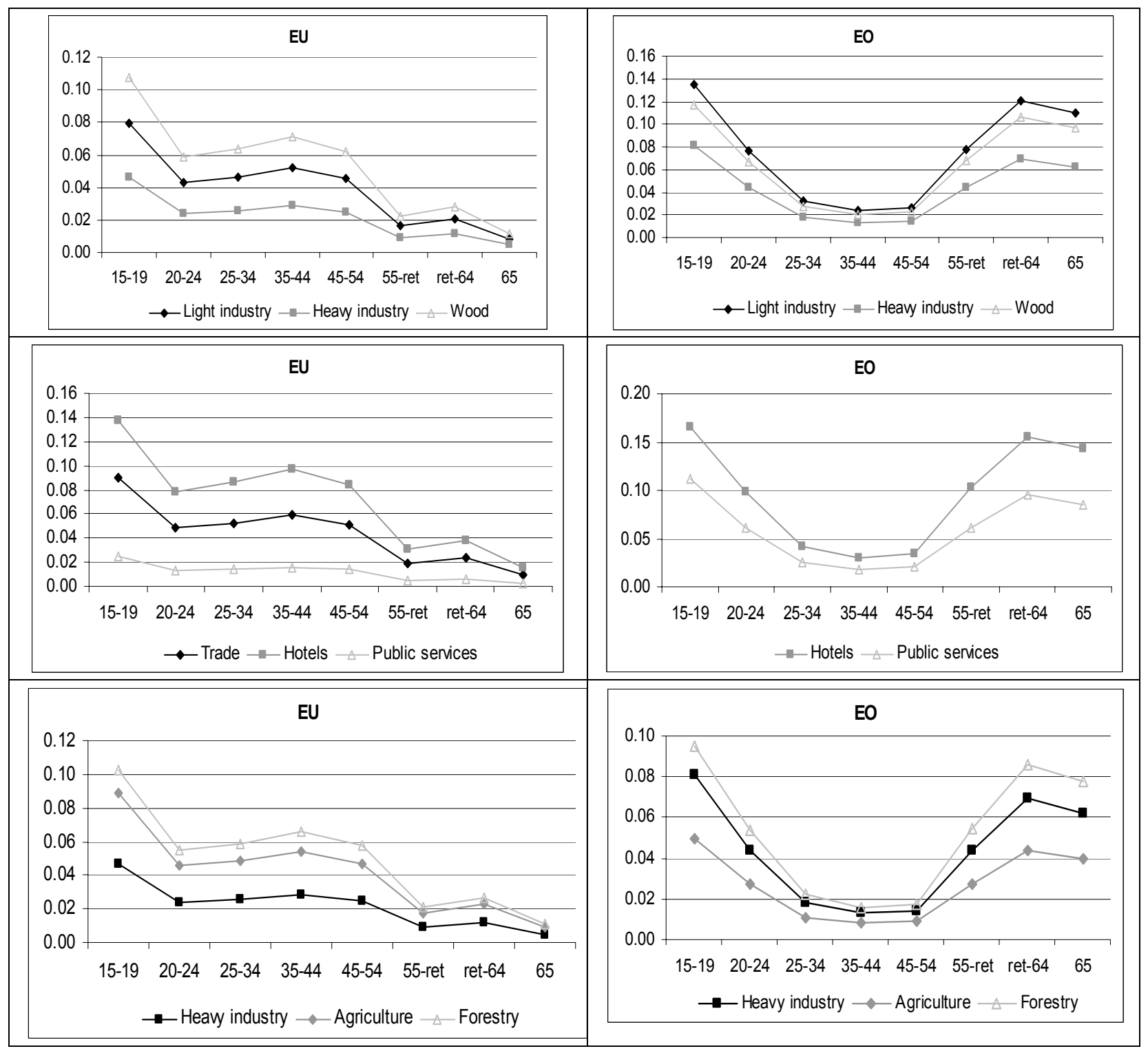

Notes: Education, gender, ethnicity, employment status, occupation, and residence are controlled (see Appendix Table 19).

Heavy industry includes also energy sector. Wood stands for manufacturing of wood products. Public services include public administration, education and health care. EO probabilities for Trade are the same as for Public services except for retirement age, when they are higher by 0.01 . "Ret" stands for retirement age.

Source: Calculations based on LFS 2002. 
Appendix Figure 18. Returns to Education by Gender (no occupation controls). The Baltic States (2000), the Czech R., Hungary and Poland (1996).

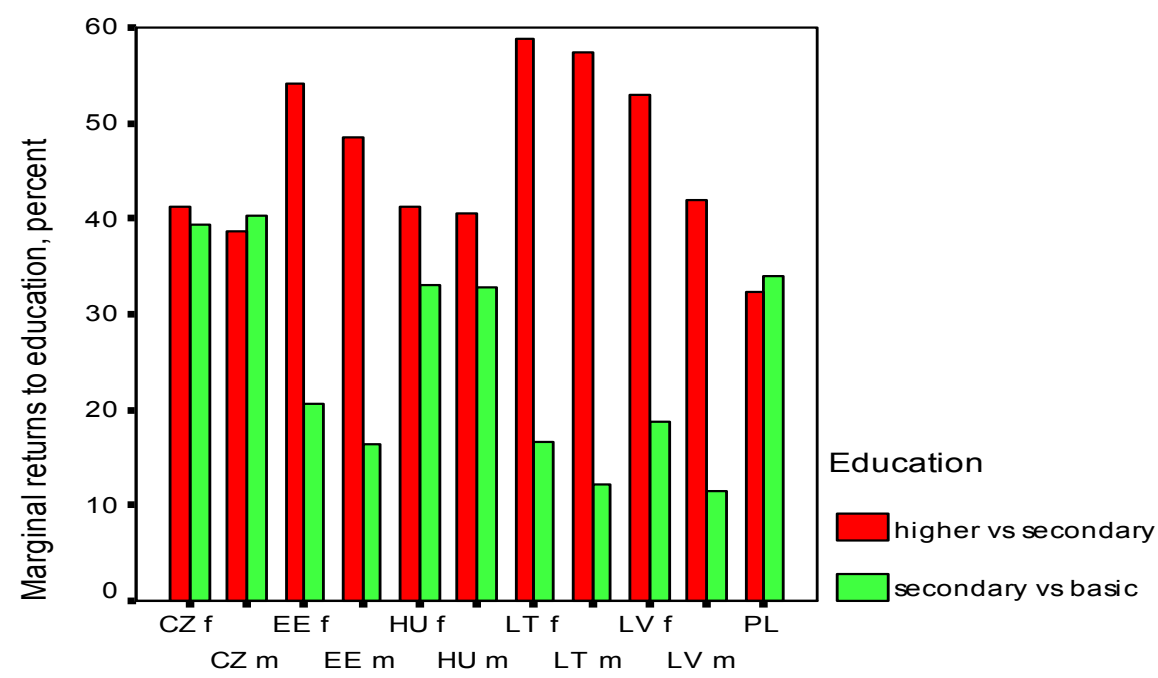

country, subpopulation

Notes: Abbreviations: $\mathrm{f}$ - females, m- males. Hungary: only non-budget sector employees. Source: OECD (2003a) and Hazans (2003d).

Appendix Figure 19. Estimated returns to education (controlling for occupation). The Baltic States (2000), Poland (1998), Czech Republic, Slovakia, Hungary (1992),

Canada, Netherlands, and US (1986 -1991)

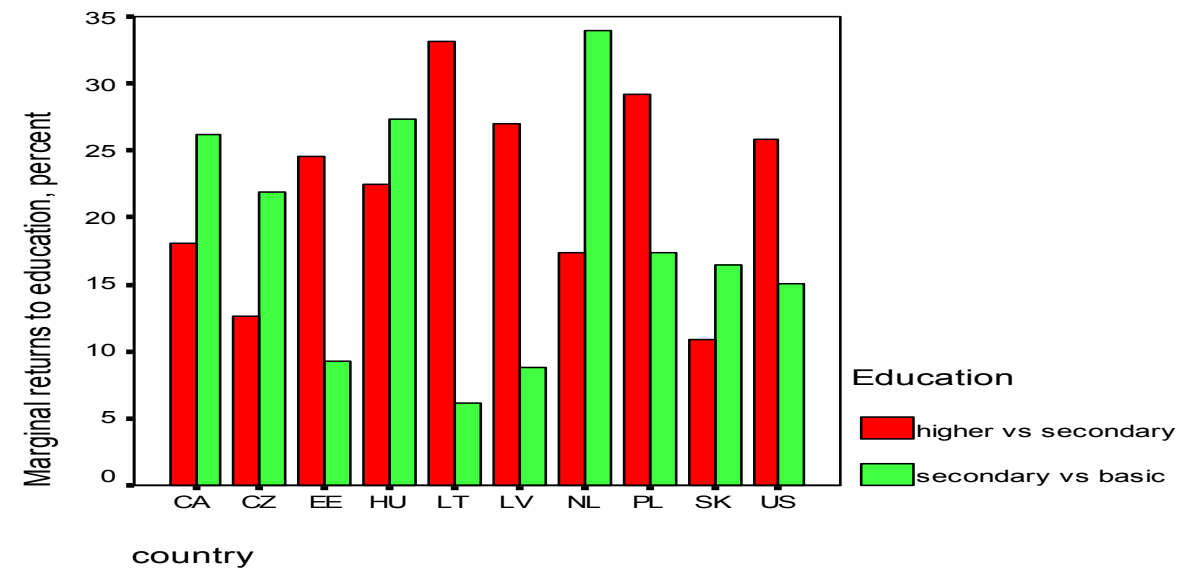

Source: OECD (2003a) and Hazans (2003d). 


\section{Appendix Figure 20. Actual Age-Earnings Profiles in 2000}

(observed after-tax earnings of full-time employees)

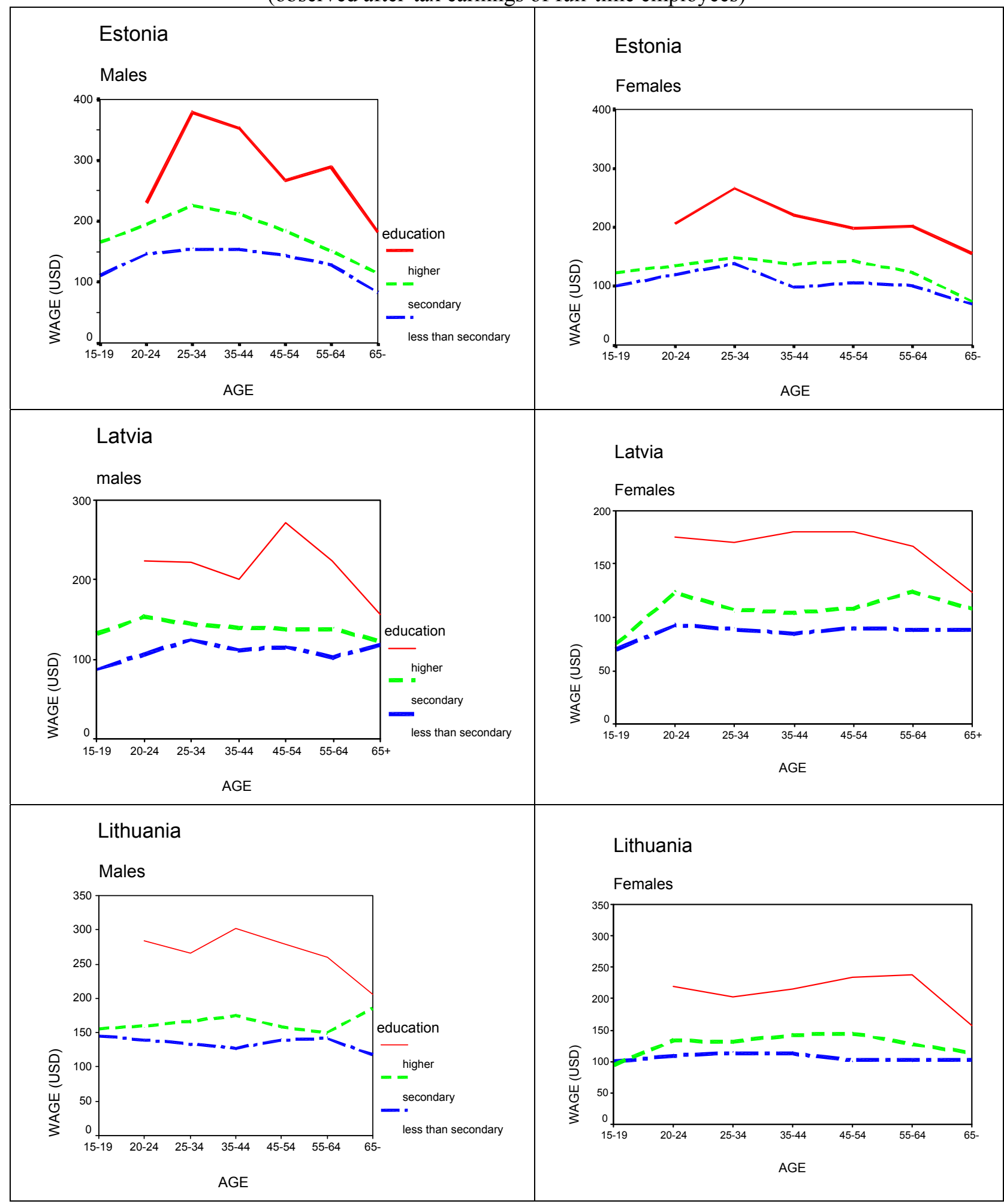

Source: OECD (2003a). 


\section{Appendix Figure 21. Female-male wage ratio vs average wage \\ in Latvian main cities and districts, 1999.}

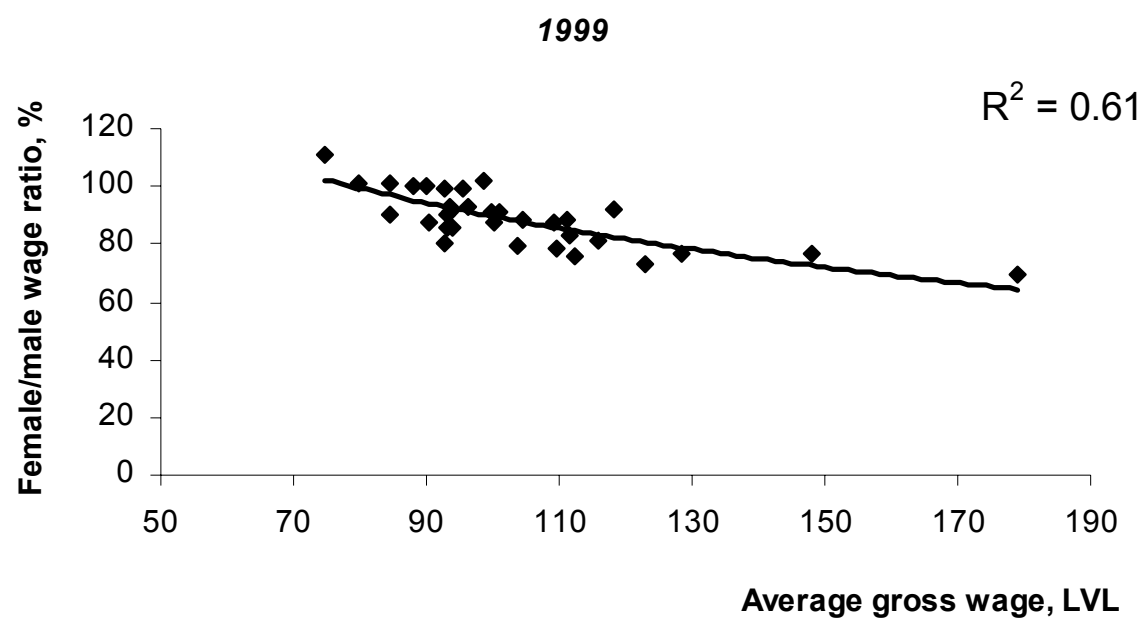

Notes: Each point represents one of the 26 districts and 7 main cities of Latvia. Fitted curve and $\mathrm{R}^{2}$ refer to estimated relationship wage ratio $=290-43.5 \ln ($ average wage $)$.

Source: Rauhmane et al (2001). 
Appendix Figure 22. Predicted Age - Activity Profiles, 1997 and 2002.
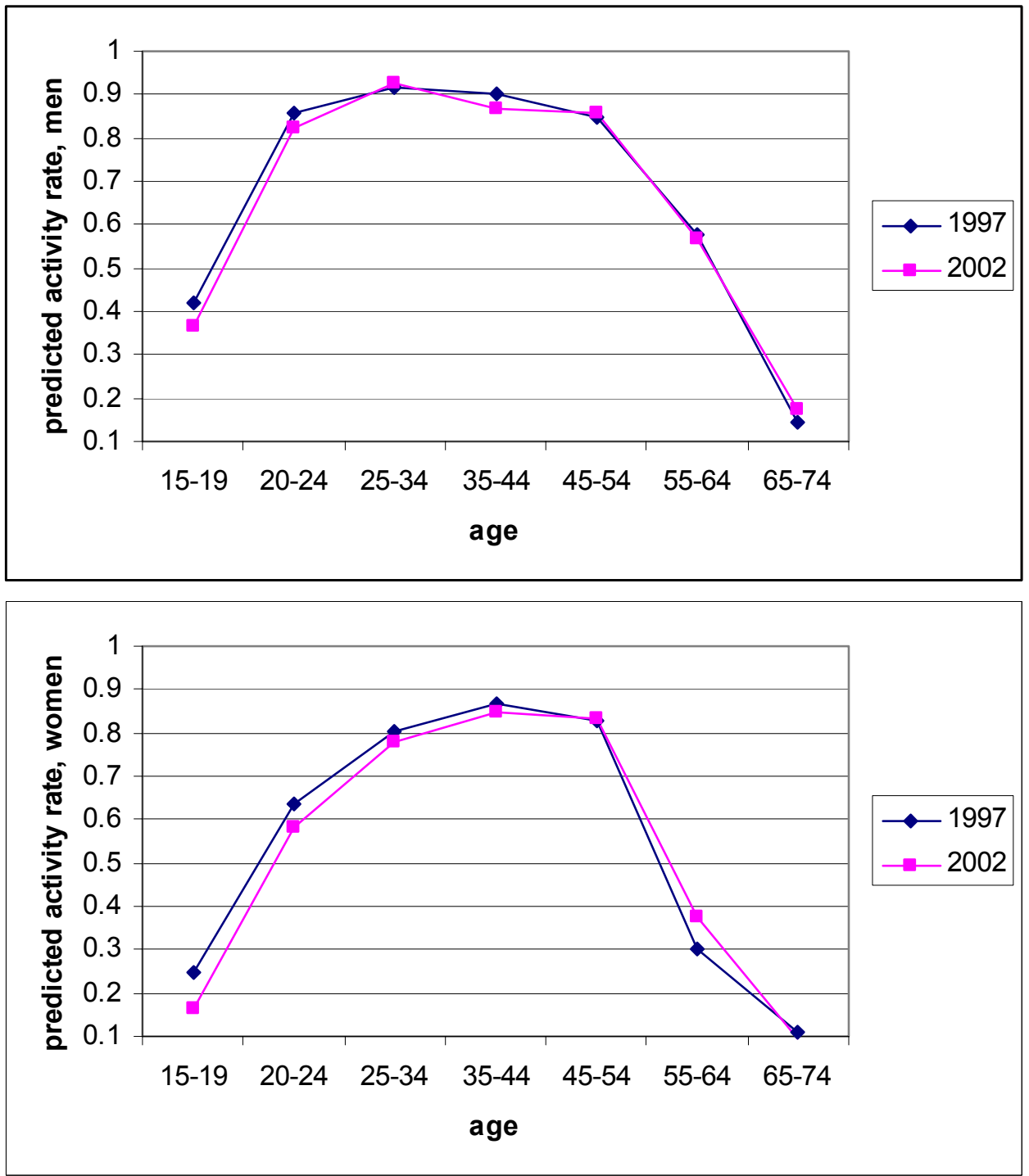

Source: Calculations based on LFS 1997 and 2002. 
Appendix Table 1. Activity, Employment and Unemployment Rates by Gender and Age. Latvia, 1997-2002

\begin{tabular}{|c|c|c|c|c|c|c|c|c|c|c|c|c|c|c|c|c|c|c|}
\hline \multirow{2}{*}{$\begin{array}{l}\text { Gender and } \\
\text { age }\end{array}$} & \multicolumn{6}{|c|}{ Labor force participation } & \multicolumn{6}{|c|}{ Employment/population ratio } & \multicolumn{6}{|c|}{$\begin{array}{l}\text { Percent } \\
\quad \text { Unemployment rate }\end{array}$} \\
\hline & 1997 & 1998 & 1999 & 2000 & 2001 & 2002 & 1997 & 1998 & 1999 & 2000 & 2001 & 2002 & 1997 & 1998 & 1999 & 2000 & 2001 & 2002 \\
\hline Men 15-64 & 76.4 & 76.4 & 75.3 & 72.5 & 72.8 & 73.9 & 64.6 & 65.2 & 63.9 & 61.2 & 62.1 & 64.3 & 15.5 & 14.6 & 15.2 & 15.6 & 14.7 & 13.1 \\
\hline $15-19$ & 27.0 & 23.5 & 21.9 & 16.4 & 14.1 & 18.8 & 16.0 & 15.5 & 14.7 & 10.9 & 9.8 & 13.6 & 40.6 & 33.7 & 32.9 & 33.5 & 30.6 & 27.8 \\
\hline $20-24$ & 80.6 & 77.3 & 78.4 & 74.1 & 73.3 & 73.2 & 65.3 & 60.6 & 59.9 & 60.3 & 58.1 & 61.8 & 19.0 & 21.6 & 23.6 & 18.6 & 20.8 & 15.6 \\
\hline $25-54$ & 89.7 & 91.4 & 90.3 & 88.0 & 89.4 & 89.2 & 77.3 & 79.5 & 77.5 & 74.5 & 77.2 & 78.2 & 13.8 & 13.0 & 14.2 & 15.3 & 13.7 & 12.4 \\
\hline $55-59$ & 73.2 & 74.4 & 72.8 & 71.7 & 72.5 & 75.1 & 63.2 & 63.5 & 66.1 & 62.7 & 61.8 & 65.9 & 13.7 & 14.7 & 9.2 & 12.4 & 14.8 & 12.3 \\
\hline $60-64$ & 36.8 & 32.5 & 34.2 & 35.9 & 34.1 & 41.3 & 31.2 & 29.9 & 32.4 & 33.3 & 31.2 & 37.5 & 15.2 & 8.0 & 5.5 & 7.2 & 8.3 & 9.2 \\
\hline $65+$ & 11.7 & 12.5 & 14.1 & 10.6 & 10.7 & 13.0 & 10.5 & 11.8 & 12.9 & 10.2 & 10.6 & 12.0 & 10.2 & 6.2 & 8.7 & 4.1 & 1.2 & 8.0 \\
\hline Women $15-64$ & 64.9 & 63.8 & 62.5 & 62.3 & 63.3 & 64.1 & 55.0 & 54.8 & 54.0 & 53.8 & 55.8 & 57.0 & 15.3 & 14.0 & 13.7 & 13.6 & 11.9 & 11.0 \\
\hline $15-19$ & 20.1 & 15.8 & 12.8 & 9.8 & 9.6 & 11.5 & 13.7 & 8.3 & 8.3 & 5.9 & 5.8 & 6.5 & 31.5 & 47.6 & 35.7 & 39.8 & 39.4 & 43.6 \\
\hline $20-24$ & 62.9 & 63.7 & 59.4 & 55.0 & 56.7 & 58.8 & 48.0 & 49.4 & 47.8 & 43.4 & 46.3 & 47.2 & 23.8 & 22.4 & 19.4 & 21.0 & 18.4 & 19.8 \\
\hline $25-54$ & 83.7 & 83.2 & 82.5 & 83.4 & 83.5 & 82.4 & 71.5 & 72.4 & 71.7 & 72.7 & 74.3 & 74.4 & 14.6 & 12.9 & 13.0 & 12.9 & 11.1 & 9.7 \\
\hline $55-59$ & 39.8 & 39.5 & 39.7 & 41.7 & 46.1 & 56.9 & 36.4 & 37.2 & 36.2 & 38.2 & 41.7 & 52.1 & 8.6 & 6.0 & 8.7 & 8.4 & 9.7 & 8.5 \\
\hline $60-64$ & 20.8 & 17.6 & 18.5 & 17.6 & 22.0 & 23.8 & 19.5 & 16.3 & 16.7 & 16.1 & 20.5 & 22.2 & 6.1 & 7.3 & 9.8 & 8.2 & 6.5 & 6.6 \\
\hline $65+$ & 8.3 & 7.1 & 6.8 & 5.5 & 5.1 & 5.4 & 7.9 & 6.6 & 6.3 & 5.0 & 5.1 & 5.0 & 4.4 & 6.8 & 7.2 & 8.7 & 1.0 & 7.4 \\
\hline Both $\mathrm{c}$ & & & & & & & & & & & & & & & & & & \\
\hline $15-64$ & 70.4 & 69.8 & 68.6 & 67.2 & 67.9 & 68.8 & 59.6 & 59.8 & 58.7 & 57.3 & 58.8 & 60.5 & 15.4 & 14.3 & 14.5 & 14.6 & 13.3 & 12.1 \\
\hline $15+$ & 59.7 & 58.9 & 57.9 & 56.3 & 56.6 & 57.5 & 50.6 & 50.5 & 49.6 & 48.2 & 49.2 & 50.6 & 15.1 & 14.1 & 14.3 & 14.4 & 13.1 & 12.0 \\
\hline
\end{tabular}

Source: Central Statistical Bureau of Latvia; for age group 65+ (respectively, 15+) in year 2002 - World Bank staff estimates based on employment and unemployment indicators for age group 65-74 (respectively, 15-74) and demographic data. 
Appendix Table 2. Employment status by residence, 1997-2002

\begin{tabular}{|c|c|c|c|c|c|c|c|c|c|c|c|c|c|c|c|c|c|c|}
\hline & & & & & & & & & & & & & & & & & \multicolumn{2}{|c|}{ Percent } \\
\hline & \multicolumn{6}{|c|}{ Whole country } & \multicolumn{6}{|c|}{ Urban areas } & \multicolumn{6}{|c|}{ Rural areas } \\
\hline & 1997 & 1998 & 1999 & 2000 & 2001 & 2002 & 1997 & 1998 & 1999 & 2000 & 2001 & 2002 & 1997 & 1998 & 1999 & 2000 & 2001 & 2002 \\
\hline $\begin{array}{l}\text { Total } \\
\text { employed }\end{array}$ & 100 & 100 & 100 & 100 & 100 & 100 & 67.5 & 68.2 & 69.1 & 70.7 & 69.3 & 69.5 & 32.5 & 31.8 & 30.9 & 29.3 & 30.7 & 30.5 \\
\hline Employees & 80.5 & 82.6 & 83.7 & 85.0 & 84.9 & 86.2 & 93.8 & 94.2 & 91.3 & 93.2 & 93.1 & 92.7 & 52.9 & 58.4 & 59.8 & 61.8 & 66.1 & 71.5 \\
\hline $\begin{array}{l}\text { Employers } \\
\text { Own- }\end{array}$ & 3.2 & 3.2 & 3.7 & 4.2 & 4.2 & 3.2 & 3.3 & 3.0 & 4.8 & 4.0 & 4.4 & 3.5 & 2.6 & 3.6 & 5.1 & 2.4 & 4.5 & 2.7 \\
\hline $\begin{array}{l}\text { account } \\
\text { workers }\end{array}$ & 9.9 & 8.7 & 7.3 & 6.8 & 6.1 & 6.2 & 2.2 & 2.4 & 3.1 & 2.4 & 2.2 & 3.2 & 25.6 & 21.5 & 19.0 & 18.9 & 14.1 & 13.0 \\
\hline $\begin{array}{l}\text { Total } \\
\text { self- } \\
\text { employed } \\
\text { Unpaid }\end{array}$ & 13.1 & 11.9 & 11.0 & 11.0 & 10.3 & 9.5 & 5.5 & 5.4 & 7.9 & 6.4 & 6.5 & 6.7 & 28.2 & 25.1 & 24.1 & 21.3 & 18.6 & 15.7 \\
\hline $\begin{array}{l}\text { family } \\
\text { workers }\end{array}$ & 6.3 & 5.4 & 5.1 & 3.9 & 4.6 & 4.3 & 0.6 & 0.2 & 0.5 & 0.3 & 0.2 & 0.6 & 18.7 & 16.3 & 15.3 & 16.9 & 14.7 & 12.8 \\
\hline Unspecified & 0.1 & 0.1 & 0.2 & 0.1 & 0.2 & 0.0 & 0.1 & 0.2 & 0.3 & 0.1 & 0.1 & 0.0 & 0.2 & 0.2 & 0.3 & 0.3 & 0.5 & 0.0 \\
\hline
\end{tabular}

Appendix Table 3. Secondary employment, part-time employment and underemployment, 1997-2002

\begin{tabular}{|c|c|c|c|c|c|c|c|c|c|}
\hline \multicolumn{10}{|c|}{ (per cent of total employment) } \\
\hline & \multicolumn{3}{|c|}{$\begin{array}{l}\text { Secondary } \\
\text { employment }\end{array}$} & \multicolumn{3}{|c|}{$\begin{array}{l}\text { Part-time } \\
\text { employment }\end{array}$} & \multicolumn{3}{|c|}{$\begin{array}{c}\text { Underemployment } \\
\text { (involuntary part-time } \\
\text { employment) }\end{array}$} \\
\hline & total & men & women & total & men & women & total & men & women \\
\hline 1997 & 6.3 & 6.5 & 6.2 & 13.3 & 12.5 & 14.1 & 7.9 & 8.9 & 6.9 \\
\hline 1998 & 4.9 & 5.1 & 4.7 & 12.7 & 12.4 & 13.1 & 7.6 & 8.5 & 6.7 \\
\hline 1999 & 4.7 & 4.6 & 4.8 & 12.0 & 10.7 & 13.3 & 7.0 & 7.6 & 6.3 \\
\hline 2000 & 4.7 & 4.1 & 5.2 & 11.2 & 9.7 & 12.8 & 6.5 & 7.2 & 5.8 \\
\hline 2001 & 4.9 & 4.5 & 5.4 & 10.1 & 8.6 & 11.7 & 5.2 & 5.1 & 5.3 \\
\hline 2002 & 7.1 & 6.4 & 7.9 & 9.9 & 7.5 & 12.2 & 4.4 & 4.1 & 3.6 \\
\hline
\end{tabular}


Appendix Table 4. Distribution of labor force and unemployment rates by education, residence, ethnicity and command of Latvian language

\begin{tabular}{|c|c|c|c|c|c|c|}
\hline & \multicolumn{3}{|c|}{ Labor Force Distribution } & \multicolumn{3}{|c|}{ Unemployment rates } \\
\hline & Total & Males & Females & Total & Males & Females \\
\hline \multicolumn{7}{|l|}{ Education } \\
\hline Higher & 19.4 & 15.6 & 23.4 & 5.7 & 6.3 & 5.4 \\
\hline Upper secondary $^{a}$ & 61.3 & 61.4 & 61.3 & 13.2 & 13.7 & 12.7 \\
\hline Below upper secondary ${ }^{\mathrm{b}}$ & 19.2 & 23.0 & 15.3 & 21.3 & 23.2 & 18.3 \\
\hline \multicolumn{7}{|l|}{ Residence } \\
\hline Urban & 70.4 & 68.7 & 72.2 & 14.6 & 16.3 & 13.0 \\
\hline of which Riga & 33.7 & 33.0 & 34.3 & 11.1 & 12.3 & 10.0 \\
\hline $\begin{array}{l}\text { Ethnicity and } \\
\text { language skills }\end{array}$ & 29.6 & 31.3 & 27.8 & 10.2 & 11.2 & 8.9 \\
\hline Latvians & 57.7 & 57.5 & 57.9 & 9.7 & 10.5 & 8.9 \\
\hline Non-Latvians & 42.3 & 42.5 & 42.1 & 18.2 & 20.4 & 15.8 \\
\hline With Latvian Language skills ${ }^{c}$ & & & & 12.7 & & \\
\hline Latvians & & & & 11.4 & & \\
\hline Non-Latvians & & & & 15.0 & & \\
\hline Without Latvian language skills ${ }^{c}$ & & & & 20.8 & & \\
\hline
\end{tabular}

Notes: ${ }^{\mathrm{a}}$ Including general secondary, technical secondary, postsecondary vocational.

${ }^{\mathrm{b}}$ Including basic or incomplete basic education, as well as basic with vocational. ${ }^{\mathrm{c}}$ Population Census 2000 results, age group 15-64.

Appendix Table 5. Unemployed persons by education level and duration of unemployment, Latvia, 2002.

(per cent of unemployed persons with given education level)

\begin{tabular}{|c|c|c|c|c|c|c|}
\hline \multirow[b]{2}{*}{$\begin{array}{l}\text { Duration of } \\
\text { unemployment }\end{array}$} & \multicolumn{5}{|c|}{ Education level } & \multirow[b]{2}{*}{ Total } \\
\hline & Higher & $\begin{array}{l}\text { Post- } \\
\text { secondary } \\
\text { vocational }\end{array}$ & $\begin{array}{l}\text { General secondary } \\
\text { or post-secondary } \\
\text { vocational after basic }\end{array}$ & $\begin{array}{l}\text { Technical } \\
\text { secondary }\end{array}$ & $\begin{array}{l}\text { Basic } \\
\text { or less }\end{array}$ & \\
\hline $\begin{array}{l}\text { Less than } \\
3 \text { months }\end{array}$ & 26.0 & 23.5 & 19.2 & 18.8 & 15.8 & 19.6 \\
\hline 3 - 5 months & 19.8 & 14.3 & 17.1 & 18.7 & 13.2 & 16.2 \\
\hline $6-11$ months & 15.6 & 23.3 & 18.3 & 20.8 & 17.8 & 19.2 \\
\hline $12-23$ months & 18.8 & 11.5 & 15.8 & 9.3 & 13.7 & 13.5 \\
\hline $\begin{array}{l}24 \text { months } \\
\text { and more }\end{array}$ & 19.8 & 27.4 & 29.7 & 32.4 & 39.5 & 31.5 \\
\hline Total & 100.0 & 100.0 & 100.0 & 100.0 & 100.0 & 100.0 \\
\hline
\end{tabular}



Appendix Table 6. Incidence of long-term unemployment in the Baltic countries, 1997-2002

Percentage of all unemployed persons

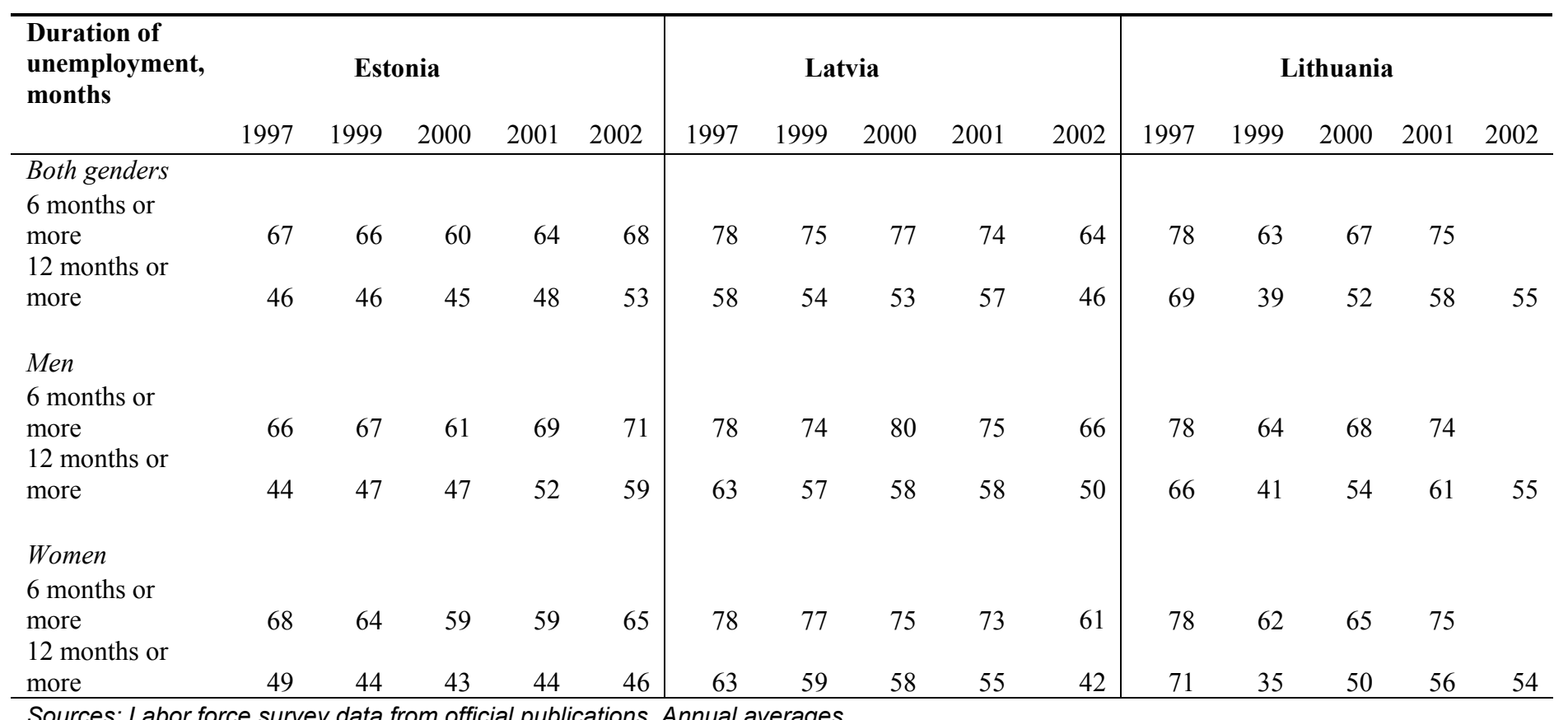



Appendix Table 7. Jobseekers looking for a job as employees by age and preferred type of job (fulltime or part-time) in 2002.

\begin{tabular}{|c|c|c|c|c|c|c|c|}
\hline Age & $15-19$ & $20-24$ & $25-54$ & $55-59$ & $60-64$ & $65+$ & Total \\
\hline Preferred job & \multicolumn{7}{|c|}{ Per cent of all jobseekers } \\
\hline Fulltime & 43 & 54 & 63 & 57 & 29 & 31 & 59 \\
\hline Part-time & 28 & 15 & 4 & 6 & 15 & 20 & 7 \\
\hline Not specified & 30 & 31 & 33 & 37 & 57 & 49 & 34 \\
\hline \multirow[t]{2}{*}{ Number obs. } & 134 & 270 & 1430 & 121 & 43 & 22 & 2020 \\
\hline & \multicolumn{7}{|c|}{ Per cent of unemployed jobseekers } \\
\hline Fulltime & 40 & 51 & 60 & 52 & 23 & 33 & 55 \\
\hline Part-time & 26 & 18 & 4 & 3 & 14 & 21 & 8 \\
\hline Not specified & 34 & 31 & 37 & 45 & 62 & 45 & 37 \\
\hline Number obs. & 99 & 182 & 930 & 88 & 36 & 20 & 1355 \\
\hline
\end{tabular}

Source: Calculation based on LFS 2002

Appendix Table 8. Access to Paid Jobs and Impact of Commuting in Urban and Rural Labor Markets. The Baltic countries, 2000.

\begin{tabular}{|c|c|c|c|c|c|c|c|c|c|}
\hline & \multicolumn{3}{|c|}{ Estonia } & \multicolumn{3}{|c|}{ Latvia } & \multicolumn{3}{|c|}{ Lithuania } \\
\hline & Tallinn & $\begin{array}{l}\text { Other } \\
\text { Urban }\end{array}$ & Rural & Riga & $\begin{array}{l}\text { Other } \\
\text { Urban }\end{array}$ & Rural & Vilnius & $\begin{array}{l}\text { Other } \\
\text { Urban }\end{array}$ & Rural \\
\hline $\begin{array}{l}\text { Access to Jobs } \\
\text { Net Inflow: }\end{array}$ & 90.8 & 83.2 & 57.1 & 92.8 & 72.3 & 49.4 & 93.9 & 81.5 & 30.5 \\
\hline All employed & 11.0 & 4.4 & -18.1 & 12.8 & -5.0 & -9.3 & 14.8 & 5.9 & -15.8 \\
\hline $\begin{array}{r}\text { Full-time } \\
\text { employees }\end{array}$ & 14.4 & 5.8 & -24.2 & 14.5 & -5.8 & -16.6 & 16.3 & 8.6 & -35.2 \\
\hline $\begin{array}{c}\text { Share of } \\
\text { commuters }\end{array}$ & 15.1 & 25.5 & 23.6 & 16.7 & 16.3 & 32.0 & 15.6 & 20.6 & 46.6 \\
\hline Unemployment & 12.8 & 15.1 & 13.7 & 14.1 & 17.5 & 11.0 & 13.9 & 17.7 & 10.8 \\
\hline
\end{tabular}

Notes: ${ }^{a}$ All employees working in the area, $\%$ of resident labor force. ${ }^{b}$ Commuting inflow less outflow, $\%$ of resident labor force ${ }^{\mathrm{C}}$ Commuting inflow less outflow, $\%$ of resident full-time employees.

${ }^{\mathrm{d}}$ Commuters (full-time employees) working in the area, $\%$ of all full-time employees working in the area.

Source: Hazans (2003a).

Appendix Table 9. Activity, employment, and unemployment rates by region, 2002

\begin{tabular}{llllllllll}
\hline & \multicolumn{3}{c}{ Activity } & \multicolumn{4}{c}{ Employment } & \multicolumn{3}{c}{ Unemployment } \\
& all & men & women & all & men & women & all & men & women \\
Riga region & 64.7 & 72.1 & 58.6 & 57.4 & 63.6 & 52.3 & 11.3 & 11.7 & 10.9 \\
Vidzeme & 62.5 & 68.1 & 57.4 & 56.1 & 61.0 & 51.5 & 10.3 & 10.4 & 10.2 \\
Zemgale & 60.9 & 69.0 & 53.8 & 54.8 & 60.8 & 49.4 & 10.0 & 11.8 & 8.1 \\
Kurzeme & 60.6 & 68.1 & 53.8 & 52.9 & 58.6 & 47.9 & 12.6 & 13.9 & 11.1 \\
Latgale & 55.5 & 59.5 & 51.8 & 46.0 & 47.9 & 44.3 & 17.0 & 19.5 & 14.5 \\
\hline Total & 61.8 & 68.4 & 56.0 & 54.4 & 59.6 & 49.9 & 12.0 & 12.9 & 10.9 \\
\hline \multicolumn{4}{c}{ Source: Calculation based on LFS 2002 }
\end{tabular}


Appendix Table 10. Full-time employees ${ }^{\text {a }}$ by residence and workplace. Latvia and Lithuania, 2000

\begin{tabular}{|c|c|c|c|c|c|c|c|c|}
\hline \multirow[b]{4}{*}{ Job location } & \multicolumn{8}{|c|}{ Percent within given residence } \\
\hline & \multicolumn{4}{|c|}{ Latvia } & \multicolumn{4}{|c|}{ Lithuania } \\
\hline & \multicolumn{4}{|c|}{ Residence } & \multicolumn{4}{|c|}{ Residence } \\
\hline & Riga & $\underset{1}{U} \operatorname{Urban}_{\mathrm{b}}$ & $\begin{array}{l}\text { Urban } \\
2^{f}\end{array}$ & Rural & Vilnius & $\underset{b}{U r b a n} 1$ & $\begin{array}{l}\text { Urban } \\
2^{f}\end{array}$ & Rural \\
\hline Capital city & 95.4 & 44.5 & 9.5 & 13.7 & 98.2 & 23.5 & 0.9 & 8.6 \\
\hline Urban $1^{\mathrm{b}}$ & 0.8 & 46.1 & $(0.1)^{d}$ & 0.7 & 0.0 & 64.3 & 0.0 & 1.7 \\
\hline 'Special' cities ${ }^{\mathrm{e}}$ & 0.0 & 0.0 & 0.2 & 0.4 & $(0.5)^{d}$ & 1.2 & 2.1 & 7.2 \\
\hline Urban $2^{f}$ & 1.3 & $(0.9)^{d}$ & 82.8 & 19.1 & $(0.7)^{d}$ & 6.1 & 90.2 & 30.3 \\
\hline Rural & 2.5 & 8.5 & 7.4 & 66.0 & $(0.6)^{d}$ & 2.7 & 6.8 & 52.2 \\
\hline Total & 100.0 & 100.0 & 100.0 & 100.0 & 100.0 & 100.0 & 100.0 & 100.0 \\
\hline $\begin{array}{l}\text { Different from } \\
\text { residence }\end{array}$ & 4.6 & 54.7 & 19.0 & 43.3 & 1.8 & 66.2 & 14.4 & 66.5 \\
\hline
\end{tabular}

Notes: ${ }^{\mathrm{a}}$ Employees working or living abroad excluded. ${ }^{\mathrm{b}}$ Urban areas surrounding capital city, i.e. belonging to Riga district (Latvia) and Vilnius county (Lithuania). ${ }^{\mathrm{d}}$ Based on less than 10 observations. ${ }^{\mathrm{e}}$ Port of Ventspils (Latvia); Kaunas and port of Klaipeda (Lithuania).

${ }^{\mathrm{f}}$ All urban areas excluding: capital city, Urban 1 and 'special' cities.

Source: Hazans (2003a; 2004a).

Appendix Table 11. Share of discouraged workers among population aged 15-74 by region, 2002.

\begin{tabular}{|c|c|c|c|c|c|c|}
\hline $\begin{array}{c}\text { Definiton of } \\
\text { discouragement }\end{array}$ & $\begin{array}{l}\text { Riga } \\
\text { region }\end{array}$ & Vidzeme & Kurzeme & Zemgale & Latgale & Total \\
\hline Lost hope to find a job & 0.9 & 1.0 & 1.4 & 1.4 & 2.5 & 1.3 \\
\hline $\begin{array}{l}\text { Lost hope to find a job } \\
\text { but available for work }\end{array}$ & 0.7 & 0.9 & 1.3 & 1.3 & 1.7 & 1.1 \\
\hline $\begin{array}{l}\text { Lost hope to find a job or } \\
\text { do not believe in finding a job } \\
\text { Lost hope to find a job or }\end{array}$ & 1.4 & 2.3 & 2.6 & 3.6 & 5.5 & 2.7 \\
\hline $\begin{array}{c}\text { do not believe in finding a job, } \\
\text { but available for work }\end{array}$ & 1.2 & 2.0 & 2.5 & 3.2 & 4.2 & 2.3 \\
\hline $\begin{array}{l}\text { Inactive persons not looking } \\
\text { for a job (for whatever reason), } \\
\text { but available for work }\end{array}$ & 8.1 & 5.9 & 6.8 & 8.4 & 9.3 & 7.8 \\
\hline
\end{tabular}

Source: Calculations based on LFS 2002

Appendix Table 12. Disparities in gross average wages in Latvia, 1992-2000

( 7 main cities and 26 districts, per cent of national average)

\begin{tabular}{cccccc}
\hline \multicolumn{5}{c}{ Standard deviation/average } \\
\hline Year & weighted & non-weighted & $\begin{array}{c}\text { Poorest } \\
\text { district }\end{array}$ & Ventspils & Riga \\
1992 & 21.9 & 22.3 & 60.4 & 182.7 & 118.5 \\
1993 & 33.7 & 29.5 & 57.4 & 254.8 & 117.4 \\
1994 & 25.6 & 23.5 & 59.5 & 208.7 & 114.8 \\
1995 & 22.0 & 20.0 & 61.3 & 185.5 & 113.3 \\
1996 & 22.3 & 21.1 & 61.6 & 189.8 & 114.1 \\
1997 & 21.2 & 21.0 & 61.9 & 179.7 & 114.7 \\
1998 & 18.6 & 20.3 & 60.0 & 162.0 & 115.5 \\
1999 & 16.8 & 20.2 & 59.9 & 153.3 & 116.0 \\
2000 & 16.4 & 20.1 & 61.3 & 148.3 & 115.8 \\
\hline
\end{tabular}

Source: Hazans (2003b). 
Appendix Table 13. Disparities in registered unemployment rates in Latvia, 1992-2002 (7 main cities and 26 districts)

\begin{tabular}{|c|c|c|c|c|c|c|}
\hline \multirow[b]{3}{*}{ Year } & \multicolumn{4}{|c|}{ Standard deviation } & \multirow{2}{*}{\multicolumn{2}{|c|}{$\begin{array}{l}\text { Unemploymen } \\
\text { rates by } \\
\text { main cities ano } \\
\text { districts }\end{array}$}} \\
\hline & \multicolumn{2}{|c|}{$\begin{array}{l}\text { (as percent of national } \\
\text { average unemployment } \\
\text { rate) }\end{array}$} & \multicolumn{2}{|c|}{ percentage points } & & \\
\hline & weighted & $\begin{array}{c}\text { non- } \\
\text { weighted }\end{array}$ & weighted & $\begin{array}{c}\text { non- } \\
\text { weighted }\end{array}$ & $\min$ & $\max$ \\
\hline 1992 & 44.4 & 56.5 & 0.9 & 1.2 & 0.7 & 6.5 \\
\hline 1993 & 63.2 & 71.1 & 3.7 & 4.1 & 3.0 & 18.8 \\
\hline 1994 & 89.7 & 100.1 & 5.8 & 6.5 & 2.1 & 25.3 \\
\hline 1995 & 81.6 & 98.6 & 5.3 & 6.4 & 2.0 & 26.0 \\
\hline 1996 & 73.7 & 87.6 & 5.3 & 6.3 & 2.9 & 27.8 \\
\hline 1997 & 73.4 & 84.2 & 5.1 & 5.9 & 3.0 & 27.9 \\
\hline 1998 & 56.2 & 59.7 & 5.2 & 5.5 & 4.8 & 28.2 \\
\hline 1999 & 55.7 & 59.1 & 5.1 & 5.4 & 4.8 & 27.2 \\
\hline 2000 & 62.6 & 67.8 & 4.9 & 5.3 & 3.7 & 25.6 \\
\hline 2001 & 63.0 & 68.1 & 4.9 & 5.2 & 3.6 & 26.5 \\
\hline 2002 & 61.9 & 66.8 & 4.7 & 5.1 & 3.7 & 26.2 \\
\hline
\end{tabular}

Notes: Registered unemployment rates at the end of the year; year 2002 rates used here are slightly different from the most recently published official data because calculation methodology of these rates was changed in 2003 (persons above retirement age are excluded from labor force), but for comparability old methodology was used also for 2002 here.

Source: Hazans (2003b). 


\section{Appendix Table 14. Annual flows between Employment, Unemployment and Out of the labor force. Latvia, 1997-2002.}

\begin{tabular}{lcccc}
\multicolumn{1}{l}{ May 1997-May 1998} \\
\hline $\mathrm{E}$ & 0.904 & 0.058 & 0.039 & 0.507 \\
$\mathrm{U}$ & 0.272 & 0.586 & 0.142 & 0.096 \\
$\mathrm{O}$ & 0.050 & 0.038 & 0.913 & 0.398 \\
\hline 1998 & 0.506 & 0.087 & 0.407 & \\
\hline
\end{tabular}

May 1998-May 1999

\begin{tabular}{lllll}
\hline & $\mathrm{E}$ & $\mathrm{U}$ & $\mathrm{O}$ & 1998 \\
\hline $\mathrm{E}$ & 0.911 & 0.055 & 0.034 & 0.506 \\
$\mathrm{U}$ & 0.265 & 0.544 & 0.191 & 0.087 \\
$\mathrm{O}$ & 0.044 & 0.029 & 0.927 & 0.407 \\
\hline 1999 & 0.502 & 0.082 & 0.416 & \\
\hline
\end{tabular}

May 1999-May 2000

\begin{tabular}{lcccc}
\hline & $\mathrm{E}$ & $\mathrm{U}$ & $\mathrm{O}$ & 1999 \\
\hline $\mathrm{E}$ & 0.901 & 0.039 & 0.061 & 0.502 \\
$\mathrm{U}$ & 0.304 & 0.483 & 0.213 & 0.082 \\
$\mathrm{O}$ & 0.061 & 0.017 & 0.922 & 0.416 \\
\hline 2000 & 0.486 & 0.081 & 0.433 & \\
\hline
\end{tabular}

May 2000-May 2001

\begin{tabular}{lcccc}
\hline & $\mathrm{E}$ & $\mathrm{U}$ & $\mathrm{O}$ & 2000 \\
\hline $\mathrm{E}$ & 0.916 & 0.042 & 0.042 & 0.486 \\
$\mathrm{U}$ & 0.349 & 0.490 & 0.161 & 0.081 \\
$\mathrm{O}$ & 0.067 & 0.028 & 0.904 & 0.433 \\
\hline $2001,15+$ & 0.492 & 0.076 & 0.432 & \\
\hline $2001,15-74$ & 0.530 & 0.081 & 0.389 & \\
\hline
\end{tabular}

2001-2002 (annual average)

\begin{tabular}{lcccc}
\hline & $\mathrm{E}$ & $\mathrm{U}$ & $\mathrm{O}$ & $2001,15+$ \\
\hline $\mathrm{E}$ & 0.921 & 0.042 & 0.037 & 0.492 \\
$\mathrm{U}$ & 0.310 & 0.447 & 0.243 & 0.076 \\
$\mathrm{O}$ & 0.073 & 0.035 & 0.892 & 0.432 \\
\hline $2002,15+$ & 0.506 & 0.073 & 0.422 & \\
\hline $2002,15-74$ & 0.544 & 0.074 & 0.382 & \\
\hline
\end{tabular}

Notes: $\mathrm{E}$ is employment, $\mathrm{U}$ is unemployment, and $\mathrm{O}$ is out of the labor force. Population aged 15 and older is included. For flows between 2001-2002 only employed and unemployed aged 15-74 in 2002 were used, but since this group contributed $99.7 \%$ of employment and $100 \%$ of unemployment in 2001, results are comparable. The source of the transition matrix is calculations based on the corresponding rounds of the Latvian LFS, and the source of the shares of the three states (E, U, O) in 1997-2002 is the LFS. For 2001-2002 stock estimates are given both for 15+ and 15-74 age groups to facilitate comparison between years and with official statistics for 2002. Since the transition matrix was generated using sub-samples, one cannot use it to obtain e. g. 1998 shares from 1997 shares; the difference is, however negligible. For 2000 - 2001 alternative estimates for flows from E based on retrospective information given in 2001 are $0.937,0.039$ and 0.024 (such estimates were not possible from flows from $U$ and $O$ ). Sources: OECD (2003a) for 1997-2000, Calculations based on LFS for 2000-2002. 


\section{Appendix Table 15. Annual flows between Agriculture, Industry, Services, Unemployment and Out of the labor force.}

\section{May 1997-May 1998}

\begin{tabular}{llllllr}
\hline & $\mathrm{A}$ & $\mathrm{I}$ & $\mathrm{S}$ & $\mathrm{U}$ & $\mathrm{O}$ & 1997 \\
\hline $\mathrm{A}$ & 0.726 & 0.053 & 0.097 & 0.105 & 0.019 & 0.110 \\
$\mathrm{I}$ & 0.005 & 0.868 & 0.040 & 0.056 & 0.030 & 0.128 \\
$\mathrm{~S}$ & 0.002 & 0.020 & 0.878 & 0.056 & 0.044 & 0.270 \\
$\mathrm{U}$ & 0.004 & 0.078 & 0.190 & 0.586 & 0.142 & 0.096 \\
$\mathrm{O}$ & 0.001 & 0.007 & 0.041 & 0.038 & 0.913 & 0.398 \\
\hline $\mathrm{I}$ & 0.095 & 0.137 & 0.274 & 0.087 & 0.407 & \\
\hline
\end{tabular}

May 1998-May 1999

\begin{tabular}{|c|c|c|c|c|c|c|}
\hline & A & $\bar{I}$ & $\overline{\mathrm{S}}$ & $\bar{U}$ & $\mathrm{O}$ & 1998 \\
\hline $\bar{A}$ & 0.668 & 0.029 & 0.099 & 0.092 & 0.112 & 0.095 \\
\hline I & 0.006 & 0.802 & 0.056 & 0.096 & 0.040 & 0.137 \\
\hline $\mathrm{S}$ & 0.005 & 0.013 & 0.919 & 0.036 & 0.028 & 0.274 \\
\hline $\mathrm{U}$ & 0.016 & 0.074 & 0.175 & 0.544 & 0.191 & 0.087 \\
\hline $\mathrm{O}$ & 0.005 & 0.010 & 0.028 & 0.029 & 0.927 & 0.407 \\
\hline 1999 & 0.086 & 0.130 & 0.286 & 0.082 & 0.416 & \\
\hline
\end{tabular}

May 1999-May 2000

\begin{tabular}{|c|c|c|c|c|c|c|}
\hline & A & $\bar{I}$ & $\bar{S}$ & $\overline{\mathrm{U}}$ & $\mathrm{O}$ & 1999 \\
\hline $\mathrm{A}$ & 0.734 & 0.043 & 0.067 & 0.047 & 0.110 & 0.086 \\
\hline I & 0.009 & 0.866 & 0.036 & 0.045 & 0.045 & 0.130 \\
\hline $\mathrm{S}$ & 0.007 & 0.015 & 0.893 & 0.033 & 0.051 & 0.286 \\
\hline $\mathrm{U}$ & 0.047 & 0.105 & 0.152 & 0.483 & 0.213 & 0.082 \\
\hline $\mathrm{O}$ & 0.012 & 0.016 & 0.033 & 0.017 & 0.922 & 0.416 \\
\hline 2000 & 0.070 & 0.130 & 0.286 & 0.081 & 0.433 & \\
\hline
\end{tabular}

May 2000-May 2001

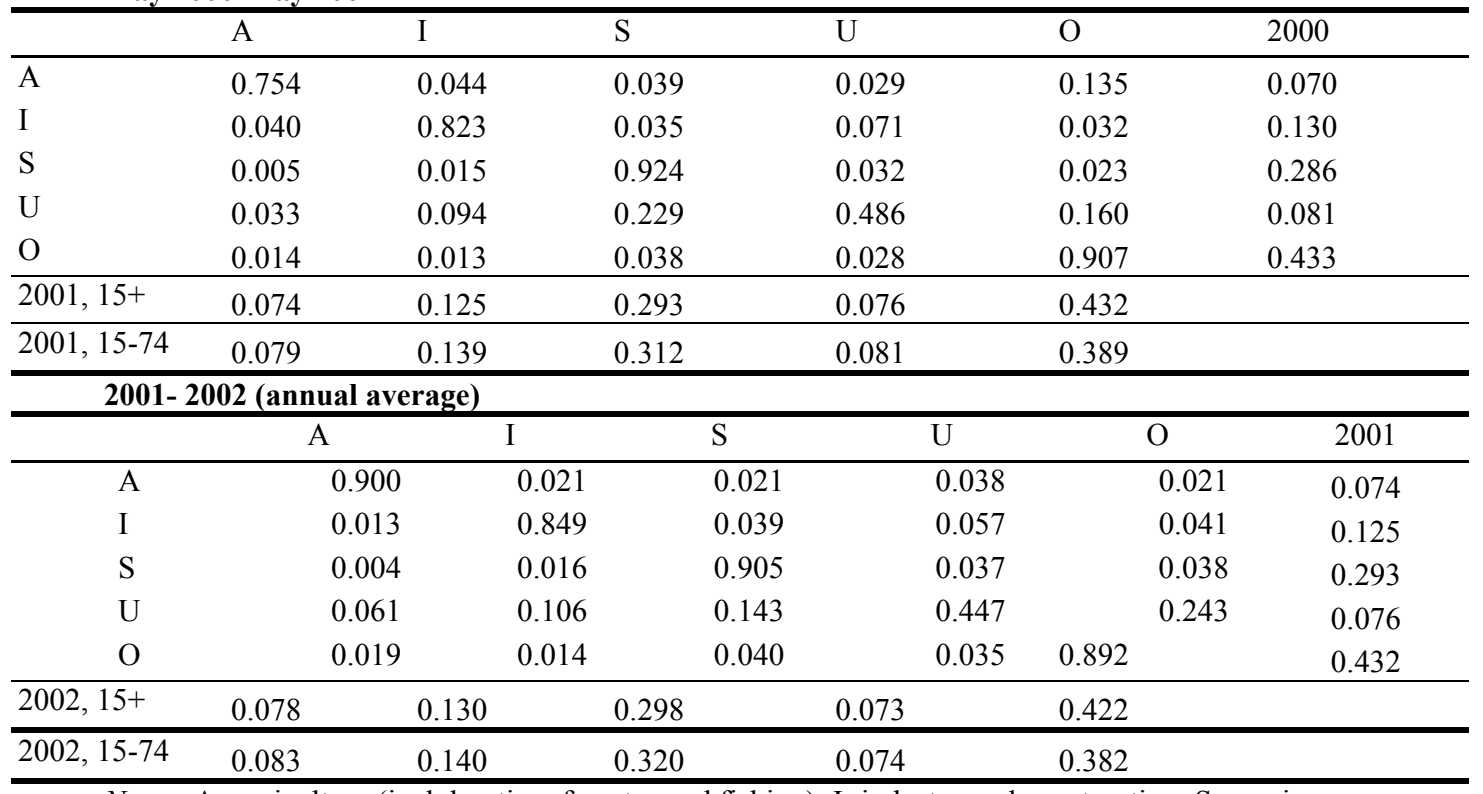

Notes: $\mathrm{A}=$ agriculture (incl. hunting, forestry and fishing); $\mathrm{I}=$ industry and construction; $\mathrm{S}=$ services;

$\mathrm{U}=$ unemployment; $\mathrm{O}=$ out of the labor force. See Notes to Appendix Table 14 for calculation details.

Sources: OECD (2003a) for 1997-2000, Calculations based on LFS for 2001-2002. 
Appendix Table 16. Ten-year flows between sectors and labour market states

\begin{tabular}{|c|c|c|c|c|c|c|c|c|}
\hline \multicolumn{9}{|c|}{ Activitv in 2000 (in \%) } \\
\hline \multirow{8}{*}{ 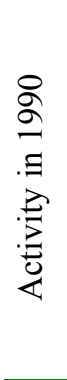 } & & $\begin{array}{l}\text { Agricul- } \\
\text { ture }\end{array}$ & Industry & $\begin{array}{l}\text { Private } \\
\text { Services }\end{array}$ & $\begin{array}{c}\text { Public } \\
\text { Services }\end{array}$ & Unemployed & $\begin{array}{l}\text { Out of the } \\
\text { labor force }\end{array}$ & Total \\
\hline & Agriculture & 13.8 & 5.2 & 8.0 & 10.9 & 21.8 & 40.2 & 18.2 \\
\hline & Industry & 0.5 & 21.1 & 15.7 & 5.9 & 20.5 & 36.2 & 19.4 \\
\hline & Private Services & 1.2 & 4.8 & 40.0 & 6.1 & 11.5 & 36.4 & 17.3 \\
\hline & Public Services & 1.2 & 1.8 & 12.1 & 43.0 & 11.5 & 30.3 & 17.3 \\
\hline & Too young & 5.9 & 14.5 & 24.3 & 15.1 & 13.8 & 26.3 & 15.9 \\
\hline & Not employed & 1.8 & 7.1 & 8.0 & 4.4 & 4.4 & 74.3 & 11.8 \\
\hline & Total & 4.2 & 9.3 & 18.3 & 14.6 & 14.7 & 38.9 & 100.0 \\
\hline
\end{tabular}

Note: Agriculture includes hunting, forestry and fishing. Industry includes construction. Private services: transports and communications; commerce; financial and real estate and other services, work for households. Public services: public administration, education, science, culture, social and health care, defense and police. Calculations based on the New Baltic Barometer, which collected data in the Spring 2000. Source: OECD (2003a).

Appendix Table 17. Determinants of success in job search by unemployed, $2001-2002$ (survey multinomial logistic regression ${ }^{\mathrm{a}}$ )

\begin{tabular}{|c|c|c|c|c|c|c|}
\hline & \multicolumn{3}{|c|}{ Exit to employment $(\mathrm{P}=0.310)$} & \multicolumn{3}{|c|}{ Exit to inactivity $(\mathrm{P}=0.243)$} \\
\hline & Coef. & t-value ${ }^{b}$ & $\begin{array}{l}\text { Marginal } \\
\text { effects }\end{array}$ & Coef. & t-value ${ }^{b}$ & $\begin{array}{l}\text { Marginal } \\
\text { effects }^{c}\end{array}$ \\
\hline \multicolumn{7}{|l|}{ Education level (vs basic), 2001} \\
\hline higher & $0.71 * *$ & 2.41 & 0.198 & -0.463 & -1.22 & -0.119 \\
\hline postsecondary vocational & $0.687 * * *$ & 2.95 & 0.167 & -0.144 & -0.51 & -0.076 \\
\hline general secondary & 0.173 & 0.85 & 0.056 & -0.268 & -1.15 & -0.059 \\
\hline secondary after vocational & $-0.775 * *$ & -2.25 & -0.108 & -0.698 & -2.02 & -0.073 \\
\hline technical secondary (vocational) & 0.247 & 0.97 & 0.068 & -0.194 & -0.65 & -0.051 \\
\hline \multicolumn{7}{|l|}{ Field of education (vs other) } \\
\hline $\begin{array}{l}\text { engineering, technology, } \\
\text { architecture, IT, mathematics }\end{array}$ & $0.439 * *$ & 2.22 & 0.089 & 0.093 & 0.36 & -0.017 \\
\hline transport and communications & $0.731^{*}$ & 1.91 & 0.172 & -0.018 & -0.04 & -0.061 \\
\hline Female & 0.009 & 0.06 & 0.000 & 0.025 & 0.15 & 0.004 \\
\hline Non-Latvian & $-0.387 * *$ & -2.41 & -0.079 & -0.035 & -0.2 & 0.022 \\
\hline \multicolumn{7}{|l|}{ Age (vs 35-44) } \\
\hline $15-19$ & 0.323 & 1.04 & 0.036 & 0.408 & 1.29 & 0.052 \\
\hline $20-24$ & $0.448 *$ & 1.86 & 0.062 & 0.429 & 1.51 & 0.044 \\
\hline $25-34$ & 0.165 & 0.88 & 0.039 & -0.052 & -0.21 & -0.021 \\
\hline $45-54$ & -0.239 & -1.3 & -0.072 & 0.326 & 1.49 & 0.080 \\
\hline 55 to retirement age & $-0.678 * *$ & -1.96 & -0.150 & 0.441 & 1.33 & 0.138 \\
\hline retirement age and older & 0.204 & 0.25 & -0.180 & $2.228 * * *$ & 3.53 & 0.488 \\
\hline \multicolumn{7}{|l|}{$\begin{array}{l}\text { Residence } \\
\text { (vs Riga region and urban) }\end{array}$} \\
\hline Vidzeme & 0.072 & 0.31 & -0.030 & $0.564 *$ & 1.93 & 0.107 \\
\hline Kurzeme & $-0.415^{*}$ & -1.88 & -0.090 & 0.126 & 0.44 & 0.053 \\
\hline Zemgale & $-0.425^{*}$ & -1.68 & -0.099 & 0.241 & 0.77 & 0.077 \\
\hline Latgale & $-0.613 * * *$ & -2.96 & -0.133 & 0.189 & 0.76 & 0.078 \\
\hline Rural & $0.673 * * *$ & 3.95 & 0.098 & $0.599 * * *$ & 2.65 & 0.058 \\
\hline Constant & $-0.498 * * *$ & 2.00 & & $-1.038 * * *$ & -3.13 & \\
\hline
\end{tabular}

Appendix Table 18. Job finding rate of jobseekers with vocational training by residence, 2001-2002. Percent

\begin{tabular}{cccc}
\hline & $\begin{array}{c}\text { Technical secondary } \\
\text { education (ISCED 3C) }\end{array}$ & $\begin{array}{c}\text { ISCED 3C followed by 1 year of general } \\
\text { secondary education (ISCED 4A) }\end{array}$ & ISCED 3C and ISCED 4A together \\
\hline Jurmala, Liepaja, Rezekne & 21 & 0 & 11 \\
Other territory & 62 & 56 & 46 \\
\hline Total in the country & 59 & 43 & 55 \\
\hline
\end{tabular}

Source of Tables 17-18: Calculations based on LFS 2002. 
Appendix Table 19. Determinants of transition from employment to unemployment or inactivity, $2001-2002$

(constrained survey multinomial logistic regression ${ }^{\mathrm{a}}$ )

\begin{tabular}{|c|c|c|c|c|c|c|}
\hline & \multicolumn{3}{|c|}{$\begin{array}{l}\text { Exit to unemployment } \\
(\mathrm{P}=0.042)\end{array}$} & \multicolumn{3}{|c|}{$\begin{array}{c}\text { Exit to inactivity } \\
(\mathrm{P}=0.037)\end{array}$} \\
\hline & Coef. & t-value ${ }^{b}$ & $\begin{array}{l}\text { Marginal } \\
\text { effects }^{c}\end{array}$ & Coef. & t-value ${ }^{b}$ & $\begin{array}{l}\text { Marginal } \\
\text { effects }\end{array}$ \\
\hline \multicolumn{7}{|l|}{ Education level (vs basic), 2001} \\
\hline higher & $-0.631 * *$ & -2.41 & -0.015 & $-0.669 * *$ & -2.36 & -0.013 \\
\hline unfinished higher (2002 graduates) & 0.646 & 0.97 & 0.026 & -0.738 & -0.74 & -0.013 \\
\hline \multicolumn{7}{|c|}{ postsecondary vocational and general } \\
\hline secondary & -0.225 & -1.27 & -0.006 & -0.165 & -0.95 & -0.004 \\
\hline secondary after vocational & 0.245 & 0.79 & 0.008 & $-0.761 *$ & -1.72 & -0.013 \\
\hline technical secondary (vocational) & -0.198 & -0.93 & -0.005 & $-0.613 * *$ & -2.49 & -0.012 \\
\hline Female & -0.022 & -0.16 & -0.001 & $0.532 * * *$ & 3.52 & 0.013 \\
\hline Non-Latvian & dropped & & & $0.362 * *$ & 2.5 & 0.009 \\
\hline Age (vs 35-44): & $0.574 *$ & 1.94 & 0.015 & $1.914 * * *$ & 6.56 & 0.116 \\
\hline $20-24$ & -0.153 & -0.72 & -0.005 & $1.238 * * *$ & 5.24 & 0.051 \\
\hline $25-34$ & -0.117 & -0.8 & -0.003 & 0.321 & 1.51 & 0.009 \\
\hline $45-54$ & -0.15 & -0.93 & -0.004 & 0.094 & 0.46 & 0.002 \\
\hline 55 - retirement age & $-1.143 * * *$ & -3.45 & -0.022 & $1.22 * * *$ & 4.58 & 0.052 \\
\hline retirement age to 64 & $-0.87^{*}$ & -1.76 & -0.019 & $1.709 * * *$ & 5.89 & 0.095 \\
\hline $65-73$ & $-1.771^{*}$ & -1.75 & -0.026 & $1.586^{* * *}$ & 4.53 & 0.086 \\
\hline \multicolumn{7}{|l|}{ Employment in 2001} \\
\hline self-employed (vs employees) & $-1.372 * * *$ & -4.19 & -0.025 & $-0.797 * *$ & -2.36 & -0.014 \\
\hline public sector (vs private sector) & 0.136 & 0.73 & 0.004 & 0.226 & 1.04 & 0.005 \\
\hline working invalid (vs other employed) & -1.059 & -1.03 & -0.019 & 0.393 & 0.66 & 0.012 \\
\hline \multicolumn{7}{|l|}{$\begin{array}{l}\text { Occupation (vs semi-skilled and unskilled } \\
\text { manual, market sales } \\
\text { and shop workers) }\end{array}$} \\
\hline white collar & $-0.411 * *$ & -2.54 & -0.011 & $-0.339 *$ & -1.99 & -0.008 \\
\hline skilled manual (incl. agricultural) & dropped & & & $-0.33^{*}$ & -1.78 & -0.007 \\
\hline \multicolumn{7}{|l|}{$\begin{array}{r}\text { Economic activity in } \mathbf{2 0 0 1} \\
\text { (vs heavy industry, publishing and printing, } \\
\text { and energy) }\end{array}$} \\
\hline agriculture & $0.61 *$ & 1.69 & 0.023 & -0.481 & -1.09 & -0.010 \\
\hline forestry and fishing & $0.826^{* *}$ & 2.48 & 0.034 & 0.242 & 0.55 & 0.005 \\
\hline light industry & $0.587 *$ & 1.82 & 0.020 & $0.616^{* *}$ & 2.29 & 0.019 \\
\hline wood products & $0.912 * * *$ & 3.14 & 0.038 & 0.485 & 1.36 & 0.013 \\
\hline construction & 0.458 & 1.59 & 0.015 & $0.653 *$ & 1.84 & 0.020 \\
\hline trade & $0.703 * * *$ & 2.63 & 0.025 & 0.417 & 1.62 & 0.011 \\
\hline hotels and restaurants & $1.261 * * *$ & 3.55 & 0.062 & $0.938 * * *$ & 2.66 & 0.032 \\
\hline transport & -0.312 & -0.81 & -0.008 & & & 0.000 \\
\hline logistics and communications & $0.651^{*}$ & 1.66 & 0.025 & & & -0.001 \\
\hline financial intermediation & $0.863^{*}$ & 1.74 & 0.038 & -1.064 & -1.03 & -0.017 \\
\hline business activities & -0.411 & -0.92 & -0.010 & -0.972 & -1.55 & -0.016 \\
\hline public services & $-0.647 * *$ & -2.11 & -0.016 & 0.341 & 1.26 & 0.010 \\
\hline other community services & 0.176 & 0.54 & 0.005 & $0.737 * * *$ & 2.66 & 0.024 \\
\hline \multicolumn{7}{|l|}{ Residence (vs Riga region and urban) } \\
\hline Vidzeme & $0.343^{*}$ & 1.94 & 0.011 & $0.453 * *$ & 2.13 & 0.012 \\
\hline Kurzeme & 0.104 & 0.56 & 0.003 & $0.522 * *$ & 2.34 & 0.015 \\
\hline Zemgale & 0.086 & 0.4 & 0.002 & $0.432 * *$ & 2.04 & 0.012 \\
\hline Latgale & $0.35 * *$ & 2.02 & 0.011 & 0.275 & 1.24 & 0.007 \\
\hline rural & $-0.65 * * *$ & -3.86 & -0.017 & -0.061 & -0.34 & -0.001 \\
\hline Constant & $-2.873 * * *$ & -8.88 & & $-4.412 * * *$ & -12.68 & \\
\hline
\end{tabular}

Notes: ${ }^{a}$ Sample size 9659 . When usual (rather than survey) mlogit is applied, pseudo R2 $=0.091, \log \mathrm{L}=-2899$. ${ }^{\mathrm{b}} \mathrm{Based}$ on robust standard errors. ${ }^{\mathrm{c}}$ Change in predicted probability of respective outcome for a given category compared to reference category, while variables not belonging to given block, are held at their mean values. Source: Calculations based on LFS 2002. 
Appendix Table 20. Districts with highest/lowest estimated (ceteris paribus) probability of exit from unemployment to emloyment in $2001-2002$

(suggesting high/low rate of job creation)

\begin{tabular}{|c|c|}
\hline $\begin{array}{l}\text { High probability } \\
\text { to find a job }\end{array}$ & $\begin{array}{l}\text { Low probability } \\
\text { to find a job }\end{array}$ \\
\hline $\begin{array}{c}\text { Cēsu rajons, } \\
\text { Talsu rajons, } \\
\text { Limbažu rajons, } \\
\text { Ludzas rajons, } \\
\text { Bauskas rajons, } \\
\text { Jēkabpils rajons, } \\
\text { Krāslavas rajons, } \\
\text { Valmieras rajons, } \\
\text { Rīgas rajons, } \\
\text { Rīga city }\end{array}$ & $\begin{array}{l}\text { Daugavpils rajons, } \\
\text { Daugavpils city, } \\
\text { Jelgavas rajons, } \\
\text { Jūrmala. } \\
\text { Madonas rajons, } \\
\text { Liepājas rajons, } \\
\text { Ventspils rajons, } \\
\text { Ventspils city, } \\
\text { Ogres rajons, } \\
\text { Gulbenes rajons }\end{array}$ \\
\hline
\end{tabular}

Appendix Table 21. Districts with highest estimated (ceteris paribus) probability of exit from employment in $2001-2002$ (suggesting high rate of job destruction)

\begin{tabular}{ccc}
\hline $\begin{array}{c}\text { High probability to } \\
\text { become unemployed }\end{array}$ & $\begin{array}{c}\text { High probability } \\
\text { to leave labor force }\end{array}$ & $\begin{array}{c}\text { Overall high probability to } \\
\text { exit from employment }\end{array}$ \\
\hline Cesu rajons, & Valkas rajons, & Daugavpils rajons, \\
Preilu rajons, & Bauskas rajons, & Ludzas rajons, \\
Talsu rajons & Madonas rajons, & Saldus rajons, \\
& Daugavpils rajons, & Talsu rajons, \\
& Ludzas rajons, & Madonas rajons, \\
& Cēsu rajons, & Cēsu rajons, \\
& Saldus rajons, & Preilu rajons, \\
& Preilu rajons, & Bauskas rajons, \\
& Jelgava city & Jelgava city \\
\hline
\end{tabular}

Source: Calculations based on LFS 2002. 


\section{Appendix Table 22. Determinants of search methods by unemployed: logit estimates (continued on the next page)}

\begin{tabular}{|c|c|c|c|c|c|c|c|c|c|c|}
\hline \multirow{3}{*}{ Variables } & \multirow{2}{*}{\multicolumn{2}{|c|}{ Mean values }} & \multicolumn{4}{|c|}{ year 2001} & \multicolumn{4}{|c|}{ year 2002} \\
\hline & & & \multicolumn{2}{|c|}{$\begin{array}{l}\text { Active search }{ }^{\mathrm{a}} \\
(\text { mean } \mathrm{P}=0.425)\end{array}$} & \multicolumn{2}{|c|}{$\begin{array}{c}\text { SES }^{\mathrm{b}} \\
(\text { mean } \mathrm{P}=0.291)\end{array}$} & \multicolumn{2}{|c|}{$\begin{array}{l}\text { Active search }{ }^{\mathrm{a}} \\
(\text { mean } \mathrm{P}=0.587)\end{array}$} & \multicolumn{2}{|c|}{$\begin{array}{c}\text { SES }^{\mathrm{b}} \\
(\text { mean } \mathrm{P}=0.358)\end{array}$} \\
\hline & 2001 & 2002 & $\mathrm{dP} / \mathrm{dx}{ }^{\mathrm{c}}$ & $z$-value ${ }^{d}$ & $\mathrm{dP} / \mathrm{dx}{ }^{\mathrm{c}}$ & z-value ${ }^{\mathrm{d}}$ & $\mathrm{dP} / \mathrm{dx}{ }^{\mathrm{c}}$ & $z$-value ${ }^{d}$ & $\mathrm{dP} / \mathrm{dx}^{\mathrm{c}}$ & $z$-value ${ }^{d}$ \\
\hline higher educ. & 0.084 & 0.093 & -0.042 & -0.50 & -0.020 & -0.23 & 0.138 & $3.54 * * *$ & -0.071 & -1.33 \\
\hline secondary educ. & 0.402 & 0.496 & 0.081 & $2.34 * *$ & -0.053 & $-1.77 *$ & 0.035 & 1.15 & -0.054 & -1.53 \\
\hline female & 0.434 & 0.448 & -0.050 & $-1.78^{*}$ & 0.084 & $2.7 * * *$ & -0.076 & $-2.49^{* *}$ & 0.106 & $3.56^{* * *}$ \\
\hline non-Latvian & 0.579 & 0.520 & 0.068 & $1.74 *$ & -0.075 & $-2.25 * *$ & 0.003 & 0.09 & -0.004 & -0.12 \\
\hline age $15-19$ & 0.054 & 0.066 & -0.063 & -0.81 & -0.102 & $-2.44 * *$ & -0.063 & -1.16 & -0.333 & $-5.48 * * *$ \\
\hline age $20-24$ & 0.151 & 0.140 & 0.060 & 0.81 & -0.153 & -0.36 & 0.012 & 0.26 & -0.177 & $-4.37 * * *$ \\
\hline age $25-34$ & 0.218 & 0.225 & -0.005 & -0.10 & -0.022 & 1.63 & 0.023 & 0.65 & -0.043 & -1.08 \\
\hline age $45-54$ & 0.237 & 0.198 & -0.023 & -0.48 & 0.067 & $4.5^{* * *}$ & -0.015 & -0.40 & 0.034 & 0.93 \\
\hline age55-retirement & 0.072 & 0.057 & -0.010 & -0.12 & 0.140 & 0 & -0.068 & -1.12 & -0.018 & -0.37 \\
\hline $\begin{array}{l}\text { retirement age } \\
\text { unemployed }>=12\end{array}$ & 0.025 & 0.048 & -0.091 & -0.76 & 0.000 & $-1.81^{*}$ & 0.016 & 0.29 & -0.302 & $-3.59 * * *$ \\
\hline months & 0.595 & 0.451 & -0.007 & -0.20 & -0.205 & $-3.88 * * *$ & 0.043 & 1.38 & -0.084 & $-2.69 * * *$ \\
\hline \multicolumn{11}{|l|}{ Last job: } \\
\hline employer & 0.010 & 0.011 & 0.428 & $2.64^{* * *}$ & & & 0.091 & 0.67 & -0.185 & $-2.42 * *$ \\
\hline agriculture & 0.037 & 0.070 & -0.058 & -0.66 & -0.094 & -1.25 & 0.022 & 0.35 & -0.047 & -0.88 \\
\hline public utilities & 0.011 & 0.016 & 0.222 & $1.99 * *$ & -0.109 & -0.99 & 0.023 & 0.20 & 0.091 & 0.68 \\
\hline auto sale & 0.015 & 0.014 & 0.390 & $2.43 * *$ & -0.076 & -0.7 & 0.114 & 1.20 & -0.063 & -0.65 \\
\hline wholesale & 0.019 & 0.014 & -0.103 & -1.20 & 0.033 & 0.37 & -0.227 & -1.37 & 0.111 & 1.01 \\
\hline retail & 0.090 & 0.097 & 0.055 & 1.02 & -0.019 & -0.42 & -0.052 & -1.01 & 0.069 & 1.04 \\
\hline hotels, restaurants & 0.019 & 0.031 & -0.013 & -0.09 & -0.083 & -0.79 & -0.083 & -1.06 & -0.140 & $-2.24 * *$ \\
\hline $\begin{array}{l}\text { transport } \\
\text { finance \& }\end{array}$ & 0.028 & 0.063 & 0.121 & $1.73 *$ & 0.078 & 1.59 & -0.107 & $-1.79 *$ & 0.104 & 1.55 \\
\hline business activities & 0.016 & 0.020 & 0.156 & 1.08 & -0.085 & -0.65 & -0.185 & $-1.67 *$ & 0.078 & 0.78 \\
\hline public services & 0.078 & 0.095 & -0.048 & -0.77 & -0.029 & -0.50 & 0.007 & 0.13 & -0.036 & -0.75 \\
\hline no experience & 0.435 & 0.221 & 0.018 & 0.42 & -0.070 & $-2.25^{* *}$ & -0.015 & -0.52 & -0.124 & $-3.42 * * *$ \\
\hline
\end{tabular}

Notes: ${ }^{\mathrm{a}}$ Active search methods: checking with employers directly; placing ads in press; trying to create own business. ${ }^{\mathrm{b}}$ State Employment Service. Respondents could indicate more than one method used. Methods not shown in the table: private employment services, reading ads,

checking with friends and relatives. ${ }^{c}$ Marginal effect: average difference in predicted probability between given category and reference category,

other things equal. ${ }^{d}$ Refers to respective beta coefficients; based on robust standard errors adjusted for clustering on disticts.

${ }^{\mathrm{e}}$ Includes post-secondary vocational, general and technical secondary education.

$*, * *, * * *$ - coefficient of respective variable different from zero at $10 \%, 5 \%, 1 \%$ significance level.

Source: Calculations based on LFS 2002. 


\section{Appendix Table 22. Determinants of search methods by unemployed: logit estimates}

\section{(continued from previous page)}

\begin{tabular}{|c|c|c|c|c|c|c|c|c|c|c|}
\hline \multirow{3}{*}{$\begin{array}{l}\text { Variables } \\
\text { Residence: }\end{array}$} & \multicolumn{6}{|c|}{ year 2001} & \multicolumn{4}{|c|}{ year 2002} \\
\hline & \multicolumn{2}{|c|}{ Mean values } & \multicolumn{2}{|c|}{$\begin{array}{l}\text { Active search } \\
(\text { mean } \mathrm{P}=0.425)\end{array}$} & \multicolumn{2}{|c|}{$\begin{array}{c}\mathrm{SES}^{\mathrm{b}} \\
\text { (mean } \mathrm{P}=0.291)\end{array}$} & \multicolumn{2}{|c|}{$\begin{array}{l}\text { Active search } \\
(\text { mean } \mathrm{P}=0.587)\end{array}$} & \multicolumn{2}{|c|}{$\begin{array}{c}\mathrm{SES}^{\mathrm{b}} \\
\text { (mean } \mathrm{P}=0.358 \text { ) }\end{array}$} \\
\hline & 2001 & 2002 & $\mathrm{dP} / \mathrm{dx}^{\mathrm{c}}$ & $z$-value ${ }^{d}$ & $\mathrm{dP} / \mathrm{dx}^{\mathrm{c}}$ & z-value ${ }^{d}$ & $\mathrm{dP} / \mathrm{dx}{ }^{\mathrm{c}}$ & $z$-value ${ }^{d}$ & $\mathrm{dP} / \mathrm{dx}{ }^{\mathrm{c}}$ & $z$-value ${ }^{d}$ \\
\hline rural & 0.228 & 0.223 & -0.080 & $-1.83^{*}$ & -0.111 & $-2.81 * * *$ & 0.223 & -0.068 & -1.45 & -0.035 \\
\hline \multicolumn{11}{|l|}{$\begin{array}{l}\text { DistrIcts (vs Riga } \\
\quad \text { region }{ }^{\mathrm{f}} \text { ) }\end{array}$} \\
\hline Daugavpils ${ }^{\mathrm{g}}$ & 0.103 & 0.081 & -0.009 & -0.15 & 0.141 & $2.23 * *$ & 0.081 & 0.077 & 1.07 & 0.184 \\
\hline Jelgavas $^{\mathrm{g}}$ & 0.031 & 0.050 & -0.242 & -1.01 & 0.353 & $5.49 * * *$ & 0.050 & 0.132 & 1.17 & 0.205 \\
\hline Liepājas $^{\mathrm{g}}$ & 0.083 & 0.051 & -0.054 & $-2.81 * * *$ & 0.269 & $7.24 * * *$ & 0.051 & 0.033 & 0.44 & -0.027 \\
\hline Rēzeknes $^{\mathrm{g}}$ & 0.053 & 0.065 & -0.170 & $-3.00 * * *$ & 0.283 & $6.47 * * *$ & 0.065 & -0.180 & $-2.14 * *$ & 0.200 \\
\hline Ventspils $^{\mathrm{g}}$ & 0.036 & 0.027 & -0.098 & -1.09 & 0.251 & $4.33 * * *$ & 0.027 & 0.395 & $6.33 * * *$ & 0.155 \\
\hline Aizkraukles & 0.028 & 0.011 & 0.178 & 1.41 & -0.005 & -0.08 & 0.011 & 0.313 & $2.93 * * *$ & -0.216 \\
\hline Alūksnes & 0.011 & 0.000 & 0.165 & 1.01 & 0.323 & $2.07 * *$ & n.a. & n.a. & n.a. & n.a. \\
\hline Balvu & 0.008 & 0.022 & 0.098 & 1.01 & 0.470 & $5.36^{* * *}$ & 0.022 & 0.007 & 0.07 & 0.212 \\
\hline Bauskas & 0.010 & 0.018 & -0.117 & -0.99 & -0.032 & -0.60 & 0.018 & 0.408 & $3.48 * * *$ & 0.020 \\
\hline Cēsu & 0.014 & 0.016 & 0.335 & $2.05^{* *}$ & 0.103 & 0.95 & 0.016 & -0.067 & -0.37 & 0.291 \\
\hline Dobeles & 0.013 & 0.012 & -0.111 & -0.84 & 0.344 & $3.64 * * *$ & 0.012 & 0.084 & 0.63 & 0.066 \\
\hline Gulbenes & 0.013 & 0.025 & 0.413 & $5.69 * * *$ & 0.157 & $2.85 * * *$ & 0.025 & 0.424 & $4.69 * * *$ & 0.030 \\
\hline Jēkabpils & 0.019 & 0.007 & 0.112 & 1.29 & 0.163 & $3.48 * * *$ & 0.007 & 0.352 & $1.94 *$ & -0.100 \\
\hline Krāslavas & 0.015 & 0.027 & -0.405 & $-2.7 * * *$ & 0.739 & $7.16^{* * *}$ & 0.027 & 0.462 & $3.40 * * *$ & 0.305 \\
\hline Kuldīgas & 0.008 & 0.013 & -0.030 & -0.19 & 0.539 & $3.21 * * *$ & 0.013 & 0.299 & $2.54 * * *$ & 0.229 \\
\hline Limbažu & 0.016 & 0.010 & -0.146 & -1.26 & -0.007 & -0.08 & 0.010 & 0.258 & $2.55 * * *$ & -0.128 \\
\hline Ludzas & 0.018 & 0.010 & 0.122 & 1.17 & 0.554 & $8.92 * * *$ & 0.010 & 0.221 & 1.52 & -0.058 \\
\hline Madonas & 0.019 & 0.012 & 0.115 & $1.78^{*}$ & 0.301 & $4.39 * * *$ & 0.012 & 0.354 & $2.27 * *$ & 0.191 \\
\hline Ogres & 0.028 & 0.020 & 0.251 & $5.58 * * *$ & -0.092 & -0.80 & 0.020 & 0.158 & 1.60 & 0.006 \\
\hline Preiļu & 0.021 & 0.024 & -0.045 & -0.87 & 0.214 & $4.49 * * *$ & 0.024 & 0.227 & 1.46 & 0.019 \\
\hline Saldus & 0.017 & 0.018 & -0.054 & -0.47 & 0.012 & 0.17 & 0.018 & 0.263 & $2.33 * *$ & 0.002 \\
\hline Talsu & 0.014 & 0.023 & 0.254 & $1.79 *$ & 0.070 & 0.66 & 0.023 & 0.182 & 1.29 & 0.108 \\
\hline Tukuma & 0.010 & 0.019 & 0.330 & $2.34 * *$ & 0.023 & 0.40 & 0.019 & 0.188 & 1.44 & -0.153 \\
\hline Valkas & 0.019 & 0.015 & 0.095 & 1.01 & 0.036 & 0.72 & 0.015 & 0.322 & $1.98 * *$ & 0.003 \\
\hline Valmieras & 0.020 & 0.027 & 0.175 & $2.82 * * *$ & -0.057 & -1.46 & 0.027 & 0.117 & 1.03 & 0.041 \\
\hline Observations & 1118 & 1419 & & & 11 & 18 & 14 & & & \\
\hline Pseudo R2 & & & & & 0.1 & 83 & 0.1 & & & \\
\hline $\log L$ & & & & & -55 & 0.7 & -86 & & & \\
\hline
\end{tabular}


Appendix Table 23. Districts of Latvia by search methods of unemployed and unemployment rate. 2001 (May) and 2002 (annual average).

A. High unemployment districts ${ }^{\text {a }}$.

\begin{tabular}{|c|c|c|l|}
\hline \multirow{2}{*}{$\begin{array}{c}\text { Likelihood of using } \\
\text { active methods } \\
\text { (ceteris paribus) } \\
\downarrow\end{array}$} & \multicolumn{2}{|c|}{ Likelihood of using State Employment Service by unemployed } \\
(ceteris paribus)
\end{tabular}

B. Medium and low unemployment districts.

\begin{tabular}{|c|c|c|c|}
\hline & \multicolumn{2}{|c|}{ Likelihood of using State Employment Service by unemployed } \\
(ceteris paribus)
\end{tabular}

Notes. ${ }^{a}$ Sampling procedure of LFS 2002 does not allow reliable estimates of unemployment rates by NUTS4 regions (districts), therefore registered unemployment rates were used. All districts categorized as high unemployment ones have had registered unemployment $10 \%$ or higher (and also higher than average ILO unemployment in 2001).

* Districts which are on the margin of high unemployment. Source: Calculation based on LFS. 
Appendix Table 24. Estimated ceteris paribus wage differentials associated with education, gender, ethnicity, marital status, job tenure, contract type, local unemployment rate, and job location, when occupation is not controlled for. Latvia, 2002.

Percent

\begin{tabular}{|c|c|c|c|c|c|c|c|c|c|c|c|c|}
\hline & & & & & Gender & & Ethnicity & & Ownershi & sector & Job locat & \\
\hline & (1) & (2) & (3) & (4) & (5) & (6) & (7) & (8) & (9) & (10) & $(11)$ & (12) \\
\hline Employees & all & fulltime & fulltime & fulltime & male & female & Latvian & $\begin{array}{l}\text { non- } \\
\text { Latvian }\end{array}$ & public & private & urban & rural \\
\hline Education (vs basic or less) & & & & & & & & & & & & \\
\hline higher & 82 & 77 & 79 & 77 & 66 & 90 & 86 & 64 & 101 & 62 & 77 & 88 \\
\hline postsecondary vocational & 25 & 23 & 24 & 23 & 22 & 28 & 25 & 19 & 31 & 19 & 24 & 24 \\
\hline secondary & 18 & 16 & 17 & 17 & 16 & 19 & 20 & 10 & 21 & 15 & 18 & 12 \\
\hline secondary after vocational & 12 & 13 & 13 & 13 & 12 & 17 & 2 & 29 & 18 & 12 & 18 & 5 \\
\hline secondary vocational & 13 & 10 & 11 & 11 & 10 & 12 & 9 & 11 & 13 & 10 & 12 & 4 \\
\hline Female & -24 & -25 & -24 & -25 & & & -25 & -24 & -23 & -26 & -25 & -23 \\
\hline non-Latvian & -13 & -14 & -13 & -13 & -13 & -13 & & & -11 & -13 & -13 & -12 \\
\hline Single & -8 & -8 & -9 & -8 & -14 & -4 & -7 & -10 & -5 & -11 & -8 & -8 \\
\hline Job tenure & 1.3 & 1.2 & 1.2 & 1.2 & 1.3 & 1.2 & 0.9 & 1.7 & 0.7 & 1.6 & 1.2 & 1.0 \\
\hline Tenure less than 1 year & -7 & -7 & -7 & -7 & -6 & -6 & -7 & -6 & -10 & -6 & -7 & -5 \\
\hline Temporary or seasonal job & -13 & -12 & -12 & -12 & -12 & -10 & -14 & -8 & -10 & -13 & -12 & -12 \\
\hline $\begin{array}{l}\text { Unemployment rate at job } \\
\text { location, percent }{ }^{\mathrm{a}}\end{array}$ & -2.2 & & -2.3 & -2.5 & -3.2 & -1.8 & -2.4 & -2.7 & -1.9 & -3.5 & -2.4 & -2.6 \\
\hline $\begin{array}{l}\text { Wage curve elasticity } \\
\text { Job location (vs other cities) }\end{array}$ & -0.17 & & -0.18 & -0.19 & -0.24 & -0.13 & -0.18 & -0.21 & -0.15 & -0.26 & -0.18 & -0.19 \\
\hline Riga & 13 & 37 & 14 & 14 & 15 & 12 & 14 & 13 & 5 & 15 & 14 & \\
\hline Riga district & 19 & 27 & 19 & 19 & 18 & 17 & 15 & 27 & 1 & 25 & 18 & 20 \\
\hline Jurmala & 18 & 22 & 19 & 21 & 33 & 10 & 28 & 11 & 7 & 34 & 21 & \\
\hline Ventspils & 13 & 22 & 13 & 12 & 16 & 8 & 12 & 9 & 14 & 11 & 12 & \\
\hline Liepaja & 6 & 8 & 9 & 10 & 15 & 5 & 8 & 17 & -2 & 21 & 11 & \\
\hline Daugavpils & -13 & -11 & -13 & -13 & -13 & -12 & -15 & -12 & -15 & -13 & -12 & \\
\hline Rural & -10 & -10 & -9 & -9 & -7 & -11 & -7 & -12 & -11 & -7 & -18 & \\
\hline Hours worked per week & 0.5 & & 0.9 & & & & & & & & & \\
\hline Parttime employee & -18 & & & & & & & & & & & \\
\hline
\end{tabular}

Notes: Other controles: age and its square; sector of economic activity (25 dummies). ${ }^{a}$ Derived from wage curve elasticity. Source: Calculation based on LFS 2002. 
Appendix Table 25. Estimated ceteris paribus wage differentials associated with education, gender, ethnicity, marital status, job tenure, contract type, local unemployment rate, job location, and plant size, when occupation is controlled for. Latvia, 2002.

Percent

Education (vs basic or less)

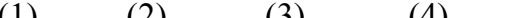

all

(6)

Ethnicity

(7)

female

Latvian

non-

(9) (10)

(10)

Job location

(11) (12)

Latvian

rural

postsecondary vocational general secondary secondary after vocational secondary vocational

Female

non-Latvian

Single

Job tenure

Tenure less than 1 year

Temporary or seasonal job

Unemployment rate at job

location, percent ${ }^{\mathrm{a}}$

Wage curve elasticity

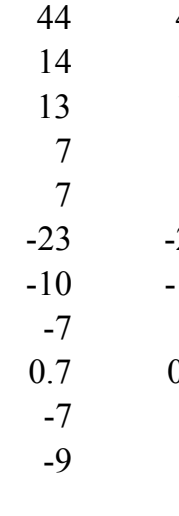

42
13
12
10
6
-24
-11
-7
0.6
-6
-8

42
14
12
8
6
-23
-10
-7
0.7
-6
-7
-2.4

$\begin{array}{rr}41 & 34 \\ 13 & 14 \\ 12 & 12 \\ 8 & 7 \\ 5 & 7\end{array}$

46
13

$\begin{array}{ll}43 & 38 \\ 12 & 14\end{array}$

47

37

$\begin{array}{ll}42 & 45\end{array}$

$\begin{array}{lll}11 & 14 & 14\end{array}$

9

14
-1

8

24

$-10 \quad-11$

$-1$

23

14

12

14

Job location (vs other cities)

$-0.18$

$-0.19$

$$
\begin{array}{r}
-2.6 \\
-0.20
\end{array}
$$$$
-12
$$$$
2
$$$$
-25
$$$$
\begin{array}{r}
7 \\
-21
\end{array}
$$$$
10
$$$$
4
$$$$
\begin{array}{r}
4 \\
-23
\end{array}
$$$$
\begin{array}{r}
-23 \\
-6
\end{array}
$$$$
\begin{aligned}
& -6 \\
& -4
\end{aligned}
$$$$
\begin{array}{ll}
0.7 & 0.8
\end{array}
$$$$
\begin{aligned}
& -9 \\
& -3
\end{aligned}
$$$$
-6
$$$$
-8
$$$$
0.7
$$$$
0.4
$$$$
\begin{array}{r}
-8 \\
1.1
\end{array}
$$$$
\begin{array}{r}
-4 \\
0.1
\end{array}
$$$$
-10
$$$$
12
$$$$
13
$$

Plant size 11-19 employees

Plant size 20-49 employees

Plant size 50 and more

$\begin{array}{rr}9 & 33 \\ 18 & 26 \\ 19 & 22 \\ 18 & 27 \\ 6 & 8 \\ -12 & -11 \\ -7 & -7 \\ 8 & 6 \\ 13 & 12 \\ 16 & 15\end{array}$

$\begin{array}{rrr}11 & 10 & 9 \\ 18 & 18 & 16 \\ 20 & 21 & 38 \\ 18 & 17 & 19 \\ 9 & 11 & 14 \\ -12 & -12 & -10 \\ -6 & -6 & -4 \\ 7 & 7 & 7 \\ 12 & 12 & 11 \\ 15 & 15 & 14\end{array}$

$\begin{array}{rrr}11 & 12 & 9 \\ 17 & 14 & 26 \\ 8 & 29 & 12 \\ 13 & 14 & 19 \\ 6 & 9 & 17 \\ -12 & -14 & -11 \\ -8 & -5 & -9 \\ 7 & 6 & 9 \\ 13 & 8 & 17 \\ 15 & 12 & 18\end{array}$

3
7
3
17
-3
-14
-9
13
16
16

11
11
23
36
16
22
-12
4
4
16

Parttime employee

0.7

Notes. Other controls: age and its square; sector of economic activity ( 25 dummies); occupation (nine major ISCO groups, with the first group subdivided in three categories - see Appendix Table 27). ${ }^{\text {a }}$ Derived from wage curve elasticity. Source: Calculation based on LFS 2002. 


\section{Appendix Table 26. Estimated ceteris paribus Wage Differentials (percent) Associated with Education, Gender, Ethnicity, Marital Status and Place of Residence: LFS 2002 vs. NORBALT 1999.}

\begin{tabular}{|c|c|c|c|c|c|c|c|c|}
\hline & \multicolumn{2}{|c|}{ (1) } & \multicolumn{2}{|c|}{ (2) } & \multicolumn{2}{|c|}{ (3) } & \multicolumn{2}{|c|}{ (4) } \\
\hline \multicolumn{9}{|l|}{ Education (vs. basic or less ${ }^{c}$ ) } \\
\hline higher & 88 & 89 & 91 & 88 & 88 & 91 & 46 & 50 \\
\hline postsecondary vocational & 28 & 26 & 28 & 27 & 27 & 26 & 14 & 15 \\
\hline secondary & 20 & 15 & 21 & 19 & 20 & 17 & 14 & 11 \\
\hline secondary vocational & 14 & 11 & 15 & 14 & 14 & 11 & 8 & 6 \\
\hline Female & -26 & -26 & -27 & -26 & -26 & -26 & -25 & -26 \\
\hline non-Latvian & -13 & -13 & -13 & -13 & -14 & -14 & -11 & -11 \\
\hline Single & -8 & -5 & -7 & -4 & -8 & -4 & -6 & -4 \\
\hline \multicolumn{9}{|c|}{$\begin{array}{l}\text { Residence ( vs. Kurzeme in models (1), (2); } \\
\text { vs. other cities in models (3), (4)) }\end{array}$} \\
\hline Riga & & & & & 27 & 23 & 26 & 22 \\
\hline Riga district & & & & & 27 & 37 & 25 & 36 \\
\hline Jurmala & & & & & 13 & 44 & 17 & 34 \\
\hline Jelgava & & & & & 10 & 7 & 9 & 8 \\
\hline Ventspils & 17 & 22 & 17 & 26 & 22 & 25 & 22 & 28 \\
\hline Liepaja & & & & & 10 & 5 & 11 & 4 \\
\hline Daugavpils & & & & & -16 & -20 & -17 & -20 \\
\hline Rezekne & & & & & -5 & -19 & -7 & -17 \\
\hline \multicolumn{9}{|l|}{ Residence (vs. Kurzeme) } \\
\hline Riga region & 21 & 22 & 21 & 22 & & & & \\
\hline Vidzeme & -1 & 4 & 0 & 3 & & & & \\
\hline Zemgale & 4 & 0 & 4 & -3 & & & & \\
\hline Latgale & -19 & -23 & -17 & -24 & & & & \\
\hline Rural & -11 & -8 & -12 & -9 & -10 & -11 & -8 & -11 \\
\hline Part time worker & & & -32 & -34 & & & & \\
\hline Industry controls ${ }^{\mathrm{d}}$ & yes & yes & yes & yes & yes & yes & yes & yes \\
\hline Occupation controls ${ }^{\mathrm{e}}$ & & no & no & no & no & no & yes & yes \\
\hline Employees included & fulltime & & & & fulltime & & fulltime & \\
\hline Number obs. & 6893 & 1723 & 8415 & 1889 & 6893 & 1723 & 6893 & 1723 \\
\hline $\mathrm{R}$ squared & n. a. & 0.377 & n. a. & 0.406 & n. a. & 0.370 & n. a. & 0.429 \\
\hline
\end{tabular}

Notes: ${ }^{\text {a }}$ Estimates derived from LFS 2002 (survey interval regression with robust standard errors). ${ }^{\mathrm{b}}$ Estimates derived from NORBALT 1999 dataset (survey linear regression with robust standard errors). ${ }^{\mathrm{c}}$ Including vocational basic. ${ }^{\mathrm{d}} 15$ major NACE sectors. ${ }^{\mathrm{e}} 9$ major groups of occupations. ${ }^{\mathrm{f}}$ All differentials reported in the table are different from zero at $1 \%$ level, with the following exceptions: Single is not significant in NORBALT specifications; Secondary vocational is significant at $10 \%$ in models $(1)^{b}$ and $(3)^{b}$, at $5 \%$ in model $(2)^{b}$, and not significant in model $(4)^{b}$; Vidzeme, Zemgale and Jelgava are never significant; Rezekne is not significant in LFS 2002 specifications; Jurmala is not significant in (3) and significant at $5 \%$ in (4) ${ }^{\mathrm{a}}$. 
Appendix Table 27. Average characteristics of fulltime employees ${ }^{\mathrm{a}}$ by gender and ethnicity,

Latvia, 2002 (percent, except for experience, tenure, age and hours)

\begin{tabular}{|c|c|c|c|c|c|}
\hline \multirow[b]{3}{*}{ Education } & \multicolumn{5}{|c|}{ Employees } \\
\hline & All & Men & Women & Latvians & $\begin{array}{c}\text { Non- } \\
\text { Latvians }\end{array}$ \\
\hline & \\
\hline Higher & 23 & 18 & 27 & 23 & 22 \\
\hline Postsecondary vocational & 21 & 17 & 25 & 19 & 23 \\
\hline General secondary & 25 & 25 & 25 & 26 & 24 \\
\hline Secondary after vocational & 3 & 3 & 2 & 3 & 3 \\
\hline Vocational (technical secondary) & 17 & 20 & 14 & 16 & 17 \\
\hline Basic (including vocational basic) or less & 12 & 17 & 8 & 13 & 12 \\
\hline Age & 40 & 39 & 40 & 39 & 41 \\
\hline Single & 35 & 29 & 42 & 37 & 34 \\
\hline Female & 49 & 0 & 100 & 49 & 49 \\
\hline Minority & 42 & 42 & 41 & 0 & 100 \\
\hline Experience, years (LFS 2000) ${ }^{b}$ & 19 & 19 & 20 & 19 & 19 \\
\hline Tenure, years ${ }^{\mathrm{e}}$ & 6.0 & 5.3 & 6.8 & 5.9 & 6.2 \\
\hline Tenure less than one year & 20 & 22 & 17 & 20 & 19 \\
\hline Usual weekly hours worked & 44 & 45 & 43 & 44 & 44 \\
\hline \multicolumn{6}{|l|}{ Type of work } \\
\hline Temporary workers & 12 & 15 & 9 & 11 & 13 \\
\hline Public sector & 38 & 32 & 45 & 42 & 34 \\
\hline \multicolumn{6}{|l|}{ Job location } \\
\hline Riga & 45 & 45 & 45 & 38 & 55 \\
\hline Riga district & 5 & 6 & 4 & 5 & 5 \\
\hline Jurmala & 1 & 1 & 2 & 1 & 2 \\
\hline Ventspils & 2 & 2 & 3 & 3 & 2 \\
\hline Liepaja & 4 & 4 & 4 & 4 & 4 \\
\hline Daugavpils & 5 & 5 & 5 & 2 & 9 \\
\hline Rural areas & 18 & 21 & 16 & 24 & 10 \\
\hline
\end{tabular}


Appendix Table 27. Average characteristics of fulltime employees ${ }^{\mathrm{a}}$ by gender and ethnicity

in Latvia, 2002 (percent, except for experience, tenure, age and hours)

(continued from previous page)

\begin{tabular}{|c|c|c|c|c|c|}
\hline \multirow[b]{3}{*}{ Industries } & \multicolumn{5}{|c|}{ Employees } \\
\hline & All & Men & Women & Latvians & $\begin{array}{c}\text { Non- } \\
\text { Latvians }\end{array}$ \\
\hline & & & & & \\
\hline Agriculture & 3 & 4 & 3 & 4 & 2 \\
\hline Forestry, fishing & 4 & 7 & 1 & 5 & 3 \\
\hline Food production & 5 & 5 & 5 & 5 & 5 \\
\hline Manufacture of textile & 1 & 1 & 2 & 1 & 2 \\
\hline $\begin{array}{l}\text { Tanning/dressing of leather, manufacture of } \\
\text { leather goods }\end{array}$ & 2 & 0 & 4 & 1 & 3 \\
\hline Manufacture of wood & 5 & 7 & 2 & 5 & 4 \\
\hline Manufacture of paper, pulp & 1 & 1 & 1 & 1 & 1 \\
\hline $\begin{array}{l}\text { Mining, fuel, manufacture of chemical and } \\
\text { plastic products }\end{array}$ & 1 & 1 & 1 & 1 & 2 \\
\hline Manufacture of minerals and metals & 1 & 2 & 1 & 1 & 2 \\
\hline Manufacture of metalsand equipment & 3 & 5 & 1 & 1 & 5 \\
\hline Other manufacture & 2 & 2 & 1 & 1 & 2 \\
\hline Electricity, gas, steam, water supply & 3 & 5 & 1 & 3 & 3 \\
\hline Construction & 7 & 12 & 1 & 6 & 8 \\
\hline Car sale & 2 & 2 & 1 & 2 & 2 \\
\hline Wholesale trade & 3 & 4 & 3 & 3 & 3 \\
\hline Retail trade & 11 & 5 & 17 & 10 & 12 \\
\hline Hotels, restaurants & 3 & 1 & 4 & 2 & 3 \\
\hline Land transport & 6 & 8 & 4 & 4 & 8 \\
\hline Other transportation, communication & 4 & 5 & 3 & 3 & 4 \\
\hline Finance & 2 & 1 & 2 & 2 & 1 \\
\hline Real Estate activities & 4 & 4 & 3 & 3 & 4 \\
\hline Public administration, defence & 8 & 9 & 8 & 11 & 4 \\
\hline Education & 9 & 4 & 14 & 10 & 6 \\
\hline Health & 7 & 2 & 11 & 7 & 6 \\
\hline Occupation & & & & & \\
\hline Senior officials & 1.4 & 1.7 & 1.0 & 1.9 & 0.6 \\
\hline Corporate managers & 5.5 & 6.1 & 4.7 & 6.7 & 3.7 \\
\hline Managers of SME & 1.8 & 1.7 & 1.9 & 2.0 & 1.5 \\
\hline Professionals & 11.7 & 7.6 & 16.0 & 12.6 & 10.4 \\
\hline Technicians & 14.0 & 9.9 & 18.2 & 15.1 & 12.4 \\
\hline Clerks & 5.7 & 1.7 & 9.9 & 6.3 & 4.9 \\
\hline Service, shop and market sales workers & 14.3 & 7.7 & 21.1 & 13.6 & 15.1 \\
\hline Skilled agricultural and fishery workers & 1.7 & 1.9 & 1.6 & 2.1 & 1.2 \\
\hline Craft and related & & & & & \\
\hline trades workers & 17.8 & 28.0 & 7.2 & 16.1 & 20.2 \\
\hline Plant and machine operators, assemblers & 12.7 & 20.2 & 4.9 & 11.4 & 14.5 \\
\hline Elementary occupations & 13.4 & 13.4 & 13.4 & 12.1 & 15.4 \\
\hline
\end{tabular}

Notes: Those who reported themselves as such and usually work at least 35 hours per week (sample used for estimation in columns (2)-(12) of Appendix Tables 24, 25).

${ }^{\mathrm{b}}$ Mean value, May 2000 (since 2001 Latvian LFS does not have a question on experience). Sources: Calculations based on LFS data. 
Appendix Table 28. Female - male wage ratios in the Baltic states (1997-2000),

Czech Republic and Poland (1997 - 1999). Percent

\begin{tabular}{|c|c|c|c|c|c|c|c|}
\hline Year & Source & Estonia $^{a}$ & Latvia $^{a}$ & Latvia $^{b}$ & Lithuania $^{b}$ & $\begin{array}{l}\text { Czech } \\
\text { Republic }^{\text {b }}\end{array}$ & Poland $^{b}$ \\
\hline 1997 & Enterprise & 72.0 & & 77.1 & 74.5 & 73 & 79 \\
\hline 1998 & survey & 74.2 & & 78.1 & 76.9 & 70 & 81 \\
\hline 1999 & on occupations, & 73.5 & & 78.5 & 81.9 & 69 & 80 \\
\hline 2000 & gross wages & 75.4 & & 78.3 & 81.3 & & \\
\hline 2001 & & & 84.0 & 81.4 & & & \\
\hline 2002 & & & 84.0 & & & & \\
\hline 2000 & LFS, net wages & 76.4 & & $81.5^{c}$ & 84.4 & & \\
\hline
\end{tabular}

Appendix Table 29. Female - male hourly gross wage ratio by occupational group in Estonia, Latvia, Lithuania, 1997-2000

Percent

\begin{tabular}{lrrrrr}
\hline Occupational group & Country & 1997 & 1998 & 1999 & 2000 \\
\hline Legislators, senior & Estonia & 74.1 & 73.5 & 74.8 & 76.5 \\
officials and managers & Latvia & 77.6 & 79.9 & 77.9 & 77.0 \\
& Lithuania & 73.7 & 70.2 & 79.3 & n.a. \\
Professionals & Estonia & 72.9 & 80.4 & 73.9 & 71.1 \\
& Latvia & 78.5 & 81.2 & 77.1 & 81.3 \\
& Lithuania & 69.2 & 74.1 & 77.9 & n.a. \\
Technicians and & Estonia & 70.0 & 70.6 & 68.2 & 70.7 \\
associate professionals & Latvia & 68.2 & 72.5 & 74.5 & 75.9 \\
& Lithuania & 74.0 & 75.7 & 81.7 & n.a. \\
Clerks & Estonia & 90.2 & 81.8 & 80.7 & 78.3 \\
& Latvia & 84.7 & 84.1 & 83.9 & 83.1 \\
& Lithuania & 78.4 & 78.1 & 82.3 & n.a. \\
Service workers, & Estonia & 63.2 & 64.0 & 63.4 & 68.4 \\
shop and market sales workers & Latvia & 66.7 & 67.8 & 69.4 & 64.6 \\
& Lithuania & $n . a$. & n.a. & n.a. & n.a. \\
Skilled agricultural and fishery workers & Estonia & 80.4 & 91.3 & 81.1 & 91.4 \\
& Latvia & 69.5 & 73.0 & 73.0 & 71.6 \\
Craft and related trades workers & Lithuania & 86.4 & 89.0 & 91.3 & n.a. \\
& Estonia & 74.3 & 76.9 & 78.5 & 84.1 \\
Plant and machine operators and assemblers & Latvia & 88.4 & 84.6 & 80.8 & 80.5 \\
& Lithuania & 93.1 & 86.8 & 88.7 & n.a. \\
& Estonia & 85.5 & 87.2 & 88.0 & 90.6 \\
Elementary occupations & Latvia & 104.5 & 106.8 & 98.6 & 98.7 \\
& Lithuania & 84.6 & 83.4 & 82.6 & n.a. \\
& Estonia & 75.6 & 74.9 & 71.1 & 74.6 \\
& Latvia & 76.0 & 71.4 & 75.9 & 75.0 \\
& Lithuania & 81.7 & 79.0 & 78.9 & n.a. \\
\hline
\end{tabular}


Appendix Table 30. Unexplained Ethnic Wage Gap in the Baltic States (1999-2002)

\begin{tabular}{llcccc} 
& & & \multicolumn{3}{c}{ Percent } \\
\hline \multicolumn{1}{c}{ Controls } & \multicolumn{1}{c}{$\begin{array}{c}\text { Non- } \\
\text { discriminatory } \\
\text { wage structure }\end{array}$} & $\begin{array}{c}\text { EE } \\
\mathbf{2 0 0 0}\end{array}$ & $\begin{array}{c}\text { LV } \\
\mathbf{2 0 0 0}\end{array}$ & $\begin{array}{c}\text { LV } \\
\mathbf{2 0 0 2}\end{array}$ & $\begin{array}{c}\text { LT } \\
\mathbf{2 0 0 0}\end{array}$ \\
\hline $\begin{array}{l}\text { Model 1: Education, age, gender, sector of } \\
\text { economic activity, ownership, regional }\end{array}$ & Pool & 17.6 & 6.0 & 12.5 & 6.8 \\
unemployment rate, major cities, rural & Est/Latv/Lith & 22.3 & 7.6 & 14.9 & 10.5 \\
$\begin{array}{l}\text { Model 2: } \\
\text { Same as Model 1, plus occupation and plant size }\end{array}$ & Pool & 14.7 & 4.3 & -3.0 & 3.8 \\
\cline { 2 - 6 } & Est/Latv/Lith & 19.3 & 6.2 & -1.3 & 6.5 \\
\hline
\end{tabular}

Notes: ${ }^{a}$ Net monthly wage. Sources: Calculations based on LFS data.

Appendix Table 31. Ceteris Paribus Relative Wages by Plant Size in the Baltic Countries.

\begin{tabular}{|c|c|c|c|c|c|c|c|c|c|}
\hline \multirow[b]{2}{*}{$\begin{array}{l}\text { Number of } \\
\text { employees }\end{array}$} & \multicolumn{3}{|c|}{ Estonia, 2000} & \multicolumn{3}{|c|}{ Latvia, 2002} & \multicolumn{3}{|c|}{ Lithuania, 2000} \\
\hline & all & $\begin{array}{l}\text { Sector } \\
\text { public }\end{array}$ & private & all & $\begin{array}{l}\text { Sector } \\
\text { public }\end{array}$ & private & all & $\begin{array}{l}\text { Sector } \\
\text { public }\end{array}$ & private \\
\hline $1-10$ & 82 & 90 & 79 & 87 & 86 & 86 & 91 & 89 & 89 \\
\hline $11-19$ & 90 & 93 & 87 & 93 & 97 & 89 & 90 & 93 & 86 \\
\hline $20-49$ & 92 & 95 & 90 & 97 & 99 & 90 & 96 & 99 & 92 \\
\hline$\geq 50$ & 100 & 100 & 100 & 100 & 100 & 100 & 100 & 100 & 100 \\
\hline
\end{tabular}

Notes: ${ }^{a}$ Education, age, gender, ethnicity, occupation, economic activity, job location are controlled for.

Sources: Calculations based on LFS data (for Estonia and Lithuania see also OECD 2003b).

Appendix Table 32. Estimated Earnings Functions Latvia, 1997 and 2002 (t-values below)

\begin{tabular}{lcccccc}
\hline & \multicolumn{2}{c}{ men } & \multicolumn{2}{c}{ women } & \multicolumn{2}{c}{ both genders } \\
& $\mathbf{1 9 9 7}$ & $\mathbf{2 0 0 2}$ & $\mathbf{1 9 9 7}$ & $\mathbf{2 0 0 2}$ & $\mathbf{1 9 9 7}$ & $\mathbf{2 0 0 2}$ \\
\hline Education (vs. basic ${ }^{\mathrm{b}}$ or less) & & & & & & \\
higher & 0.473 & 0.522 & 0.547 & 0.645 & 0.515 & 0.587 \\
& 11.88 & 13.68 & 15.60 & 14.83 & 18.93 & 20.66 \\
postsecondary vocational & 0.185 & 0.223 & 0.225 & 0.255 & 0.209 & 0.234 \\
& 6.09 & 6.22 & 7.43 & 6.02 & 9.47 & 8.81 \\
general secondary & 0.086 & 0.153 & 0.146 & 0.180 & 0.119 & 0.164 \\
& 2.87 & 4.68 & 4.74 & 4.18 & 5.33 & 6.37 \\
secondary vocational & 0.129 & 0.109 & 0.154 & 0.125 & 0.140 & 0.120 \\
& 4.06 & 3.32 & 3.52 & 2.73 & 5.30 & 4.41 \\
non-Latvian & -0.111 & -0.142 & -0.067 & -0.142 & -0.091 & -0.142 \\
& -4.65 & -6.17 & -3.17 & -6.39 & -5.52 & -8.39 \\
Age & 0.009 & 0.019 & 0.021 & 0.008 & 0.016 & 0.022 \\
& 1.54 & 3.51 & 3.85 & 1.28 & 4.00 & 5.30 \\
Age squared (coef. $\times 100)$ & -0.011 & -0.032 & -0.024 & -0.014 & -0.018 & -0.032 \\
& -1.59 & -3.78 & -3.49 & -1.88 & -3.69 & -6.25 \\
Female & & & & & -0.189 & -0.303 \\
& & & & & -11.96 & -17.29 \\
Number obs. & $\mathbf{4 5 5 4}$ & $\mathbf{3 4 2 3}$ & $\mathbf{4 3 4 4}$ & $\mathbf{3 4 7 0}$ & $\mathbf{8 8 9 8}$ & $\mathbf{6 8 9 3}$ \\
\hline
\end{tabular}

Notes: a Dependent variable log (monthly earnings). Survey interval regression method with robust standard errors has been applied. Results are not perfectly comparable between years because of different wage intervals available in the data and somewhat different categorization of secondary education. Other controls include type of contract, sector of economic activity (25 dummies), job location (dummies for 7 main cities, Riga district and rural areas), and log of registered unemployment rate at job location (by 33 NUTS4 regions). All estimated coefficients are significantly different from zero at 1\% level, except for age and age squared in men's sample 1997, and women's sample 2002. b Including basic vocational.

Source: Calculations based on LFS data. 
Appendix Table 33. Determinants of labor force participation of population aged 15-74 (logit estimates ${ }^{\mathrm{a}}$ ). Latvia, 1997 and 2002.

\begin{tabular}{|c|c|c|c|c|c|c|c|c|}
\hline & \multicolumn{2}{|c|}{ men } & \multicolumn{2}{|c|}{ men } & \multicolumn{2}{|c|}{ women } & \multicolumn{2}{|c|}{ women } \\
\hline & \multicolumn{2}{|c|}{$1997(\mathrm{P}=0.711)$} & \multicolumn{2}{|c|}{$2002(\mathrm{P}=0.684)$} & \multicolumn{2}{|c|}{$1997(\mathrm{P}=0.569)$} & \multicolumn{2}{|c|}{$2002(\mathrm{P}=0.560)$} \\
\hline & $\mathrm{dP} / \mathrm{dx}$ & t-value & $\mathrm{dP} / \mathrm{dx}$ & t-value & $\mathrm{dP} / \mathrm{dx}$ & t-value & $\mathrm{dP} / \mathrm{dx}$ & $\mathrm{t}$-value \\
\hline \\
\hline $\begin{array}{l}\text { (vs. basic or less) }^{\text {b }} \\
\text { higher }\end{array}$ & 0.137 & $7.08^{* * *}$ & 0.139 & $6.91^{* * *}$ & 0.200 & $10.44^{* * *}$ & 0.245 & $12.24^{* * *}$ \\
\hline $\begin{array}{l}\text { postsecondary } \\
\text { vocational }\end{array}$ & 0.087 & $5.12^{* * *}$ & 0.106 & $5.38^{* * *}$ & 0.129 & $8.16^{* * *}$ & 0.177 & $9.35^{* * *}$ \\
\hline general secondary & 0.054 & $3.43^{* * *}$ & 0.066 & $4.14^{* * *}$ & 0.067 & $4.39^{* * *}$ & 0.106 & $5.96^{* * *}$ \\
\hline secondary vocational & 0.125 & $6.90^{* * *}$ & 0.108 & $6.18^{* * *}$ & 0.157 & $6.76^{* * *}$ & 0.152 & $6.96^{* * *}$ \\
\hline basic with vocational & 0.076 & $2.79^{* * *}$ & 0.105 & $2.70^{* * *}$ & 0.145 & $3.05^{* * *}$ & 0.085 & 1.63 \\
\hline Non-Latvian & -0.032 & $-3.00^{* * *}$ & -0.031 & $-2.96^{* * *}$ & -0.052 & $-5.06^{* * *}$ & -0.072 & $-6.57^{* * *}$ \\
\hline Single & -0.093 & $-7.24^{* * *}$ & -0.101 & $-6.89^{* * *}$ & 0.011 & 1.05 & 0.000 & 0.00 \\
\hline With children & 0.018 & 1.62 & 0.075 & $4.22^{* * *}$ & -0.051 & $-4.53^{* * *}$ & -0.046 & $-3.49^{* * *}$ \\
\hline \multicolumn{9}{|l|}{ Age (vs. 35-44) } \\
\hline $15-19$ & -0.461 & $-14.7^{* * *}$ & -0.457 & $-15.18^{* * *}$ & -0.598 & $-19.89^{* * *}$ & -0.653 & $-20.14^{* * *}$ \\
\hline $20-24$ & -0.049 & $-2.5^{* *}$ & -0.045 & $-2.13^{* *}$ & -0.232 & $-10.17^{* * * *}$ & -0.254 & $-11.03^{* * *}$ \\
\hline $25-34$ & 0.014 & 0.95 & 0.064 & $3.87^{* * *}$ & -0.067 & $-4.15^{* * *}$ & -0.068 & $-3.90^{* * *}$ \\
\hline $45-54$ & -0.059 & $-3.42^{* * * *}$ & -0.010 & -0.58 & -0.044 & $-2.74^{* * *}$ & -0.014 & -0.88 \\
\hline $55-64$ & -0.318 & $-13.3^{* * *}$ & -0.285 & $-12.13^{* * *}$ & -0.548 & $-22.85^{* * *}$ & -0.448 & $-18.52^{* * *}$ \\
\hline $65-74$ & -0.729 & $-24.13^{* * *}$ & -0.639 & $-20.01^{* * *}$ & -0.741 & $-26.56^{* * *}$ & -0.726 & $-26.12^{* * *}$ \\
\hline \multicolumn{9}{|l|}{$\begin{array}{l}\text { Residence } \\
\text { (vs. Riga region } \\
\text { and Urban) }\end{array}$} \\
\hline Vidzeme & -0.007 & -0.42 & -0.017 & -0.98 & 0.020 & 1.06 & 0.009 & 0.49 \\
\hline Zemgale & -0.029 & -1.57 & -0.012 & -0.73 & -0.009 & -0.50 & -0.010 & -0.60 \\
\hline Kurzeme & 0.000 & 0.01 & -0.048 & $-3.17^{* * *}$ & -0.019 & -1.08 & -0.042 & $-2.43^{* *}$ \\
\hline Latgale & -0.076 & $-4.91^{* * *}$ & -0.108 & $-6.97^{* * *}$ & -0.033 & $-2.08^{* *}$ & -0.028 & $-2.03^{* *}$ \\
\hline Rural & 0.011 & 0.77 & -0.003 & -0.24 & 0.053 & $3.35^{* * *}$ & -0.006 & -0.47 \\
\hline Number obs. & \multicolumn{2}{|c|}{12395} & \multicolumn{2}{|c|}{8701} & \multicolumn{2}{|c|}{14451} & \multicolumn{2}{|c|}{10474} \\
\hline
\end{tabular}

Notes: ${ }^{\text {a }}$ Survey logistic regression; t-values are based on robust standard errors. Columns $\mathrm{dP} / \mathrm{dx}$ report means of individual marginal effects (change in predicted probability of participation for given category compared to reference category, other things equal ).

${ }^{\mathrm{b}}$ Categorization of secondary education differs somewhat between the years.

$*^{* *},,^{* * *}$ - estimates significantly different from zero at $10 \%, 5 \%, 1 \%$ level repectively.

Source: Calculations based on LFS data. 


\section{Appendix Table 34. Determinants of Unemployment Risk of Population Aged 15-74}

(logit estimates $^{\mathrm{a}}$ ). Latvia, 1997 and 2002

\begin{tabular}{|c|c|c|c|c|c|c|c|c|}
\hline & \multicolumn{2}{|c|}{ men } & \multicolumn{2}{|c|}{ men } & \multicolumn{2}{|c|}{ women } & \multicolumn{2}{|c|}{ women } \\
\hline & \multicolumn{2}{|c|}{$1997(\mathrm{P}=0.154)$} & \multicolumn{2}{|c|}{$2002(\mathrm{P}=0.129)$} & \multicolumn{2}{|c|}{$1997(\mathrm{P}=0.150)$} & \multicolumn{2}{|c|}{$2002(\mathrm{P}=0.110)$} \\
\hline & $\mathrm{dP} / \mathrm{dx}$ & $\mathrm{t}$-value & $\mathrm{dP} / \mathrm{dx}$ & $\mathrm{t}$-value & $\mathrm{dP} / \mathrm{dx}$ & t-value & $\mathrm{dP} / \mathrm{dx}$ & $\mathrm{t}$-value \\
\hline $\begin{array}{l}\text { Education } \\
\text { (vs. basic or less) }\end{array}$ & & & & & & & & \\
\hline higher & -0.104 & $-4.8^{* * *}$ & -0.116 & $-5.75 * * *$ & -0.087 & $-4.19 * * *$ & -0.070 & $-3.86 * * *$ \\
\hline postsecondary vocational & -0.085 & $-4.87 * * *$ & -0.092 & $-5.17 * * *$ & -0.046 & $-2.45 * *$ & -0.036 & $-1.96 * *$ \\
\hline general secondary & -0.020 & -1.10 & -0.073 & $-4.65 * * *$ & 0.003 & 0.14 & -0.016 & -0.86 \\
\hline secondary vocational & -0.026 & -1.37 & -0.070 & $-3.8 * * *$ & -0.038 & -1.63 & -0.029 & -1.48 \\
\hline basic with vocational & -0.002 & -0.06 & -0.080 & $-2.03 * *$ & 0.014 & 0.27 & -0.025 & -0.5 \\
\hline Non-Latvian & 0.038 & $3.35 * * *$ & 0.031 & $2.86^{* * *}$ & 0.020 & $1.73 *$ & 0.029 & $3.07 * * *$ \\
\hline Single & 0.056 & $3.98 * * *$ & 0.070 & $4.97 * * *$ & 0.031 & $2.56^{* *}$ & 0.012 & 1.26 \\
\hline With children & -0.023 & $-1.97 * *$ & -0.016 & -1.19 & 0.033 & $2.86^{* * *}$ & -0.004 & -0.31 \\
\hline $\begin{array}{l}\text { Previous experience } \\
\text { (vs. private sector and } \\
\text { Manufacturing }+ \text { Mining) }\end{array}$ & & & & & & & & \\
\hline Public sector & -0.032 & $-2.39 * *$ & 0.018 & 1.16 & -0.077 & $-5.86 * * *$ & 0.028 & 1.87 \\
\hline New entrant & 0.294 & $5.53 * * *$ & 0.429 & $13.35^{* * *}$ & 0.345 & $8.07 * * *$ & 0.292 & $8.38 * * *$ \\
\hline Agriculture & -0.209 & $-7.37 * * *$ & -0.131 & $-7.44 * * *$ & -0.262 & $-7.67 * * *$ & -0.195 & $-7.19 * * *$ \\
\hline Construction & -0.151 & $-5.82 * * *$ & -0.083 & $-3.45 * * *$ & -0.199 & $-3.36 * * *$ & -0.087 & -1.41 \\
\hline Trade, Hotels, Restaurants & -0.153 & $-6.71 * * *$ & -0.110 & $-5.33 * * *$ & -0.189 & $-8.72 * * *$ & -0.124 & $-6.49 * * *$ \\
\hline Utilities and Transport & -0.198 & $-9.18 * * *$ & -0.101 & $-4.8 * * *$ & -0.192 & $-4.76 * * *$ & -0.192 & $-6.06 * * *$ \\
\hline $\begin{array}{l}\text { Finance and Business } \\
\text { activities }\end{array}$ & -0.170 & $-3.57 * * *$ & -0.156 & $-4.82 * * *$ & -0.189 & $-4.73 * * *$ & -0.180 & $-4.56 * * *$ \\
\hline $\begin{array}{l}\text { Public administration, } \\
\text { Education, Health care, } \\
\text { Other community and }\end{array}$ & & & & & & & & \\
\hline 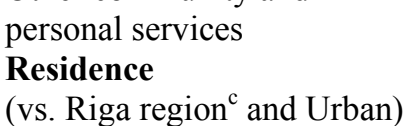 & -0.173 & $-7.47 * * *$ & -0.149 & $-7.39 * * *$ & -0.221 & $-10.37 * * *$ & -0.196 & $-9.94 * * *$ \\
\hline Jurmala & 0.035 & 1.34 & 0.189 & $5.35 * * *$ & -0.051 & $-1.77^{*}$ & 0.090 & $3.11 * * *$ \\
\hline Vidzeme & -0.013 & -0.59 & 0.015 & 0.98 & -0.023 & -1.28 & 0.031 & $2.17 * *$ \\
\hline Zemgale & 0.001 & 0.03 & 0.027 & $1.74 *$ & -0.010 & -0.5 & 0.009 & 0.65 \\
\hline Kurzeme & -0.056 & $-3.48 * * *$ & 0.036 & $2.28 * *$ & -0.049 & $-2.47 * *$ & 0.029 & $1.82 *$ \\
\hline Latgale & 0.022 & 1.21 & 0.073 & $4.93 * * *$ & -0.020 & -1.19 & 0.041 & $3.01 * * *$ \\
\hline Rural & -0.074 & $-2.94 * * *$ & -0.034 & $-2.78 * * *$ & -0.038 & $-1.82 * * *$ & -0.039 & $-3.33 * * *$ \\
\hline Number obs. & 8585 & & 5706 & & 8131 & & 5707 & \\
\hline
\end{tabular}

Notes: ${ }^{a}$ Survey logistic regression; t-values are based on robust standard errors. Columns $\mathrm{dP} / \mathrm{dx}$ report means of individual marginal effects. Age groups are controlled for but not reported; see Appendix Figure 22.

${ }^{\mathrm{b}}$ Categorization of secondary education differs slightly between the years.

${ }^{\mathrm{c}}$ Jurmala excluded.

Source: Calculations based on LFS data. 